\title{
Accessible Portfolios: Making It Happen In My Centre: An Action Research Study
}

\author{
By \\ Lynne Steele
}

\begin{abstract}
A Thesis
submitted in partial fulfillment of the requirements for the degree of Master of Education
\end{abstract}

Victoria University of Wellington

December 2007 


\begin{abstract}
This thesis explores how I improved my portfolios assessment practices by making children's portfolios freely available to children, their parents and whānau in the early childhood care and education centre where I worked. As the teacher researcher I present an insider perspective, my world view on how I improved my pedagogical practices in order to gain a deeper understanding of children's learning, and my role in supporting children's learning. This study has two components, a) the writer as the teacher researcher and, b) accessibility of children's portfolios and the involvement of children in the portfolio process.
\end{abstract}

This study uses a qualitative research design, a mixed methodology of self-study action research and case study. Three theories, ecological, sociocultural, and Donald Schön's (1983) theory of learning and practice have informed and guided this research. This eclectic mix of theoretical frameworks provided me with some valuable insights on ways of examining and using portfolios with children, and understanding children's views on their portfolios.

The findings in this study are particular to the centre where I worked and they may not be generalisable to other early childhood care and education centres. Nonetheless, my experiences highlight the potential importance of the process and issues that arise from making portfolios accessible. The findings revealed that my experiences of engaging in self-study action research promoted within the centre a community of learners, and an enquiry approach to teaching and learning. The findings of this study suggest that making portfolios freely available provides children with an understanding of the purpose, contents and ownership of their portfolios. When children frequently use and share their portfolios with peers and teachers it can promote critical self-reflection and self-assessment of their learning. Involving children in the portfolio process makes visible to children the value of their contributions to their learning. Overall, this study has significantly improved my pedagogical practices. It has enhanced teachers learning which has in turn, benefited the children's learning. Beyond that, making the portfolios accessible has strengthened parental understanding of their children's experiences at the centre. 


\section{Acknowledgements}

This research journey has been exciting and rewarding and at the same time it has been frustrating and demanding. At times, I began to wonder if I would ever complete the writing of this thesis. This thesis would have not been possible, or completed with out the patience and the support of the following people who I wish to sincerely thank:

- The children and their families in the centre where I worked for their interest, support and working with me on this research study.

- My Manager for her support, help with editing and words of wisdom on the challenges of working fulltime and studying.

- My colleagues, for their support and involvement in this study and the way they embraced the action research process.

- My supervisors Dr Carmen Dalli and Sarah Te One, for their encouragement, editing, constant reassurance and belief in me and this study.

- Deb King for her editing and constructive feedback.

- My friends for their interest and encouragement of this research. In particular, I would like to acknowledge Mavis Bates and Diane Lawrence for their hospitality and reassurance when I could not see the light at the end of the tunnel.

- My family who have always believed in me, their patience and understanding of my need to be constantly studying and especially to my husband Malcolm for looking after our children (now young adults) Matthew and Alana. You have cared for and supported me in so many ways throughout this study. 


\section{Table of Contents}

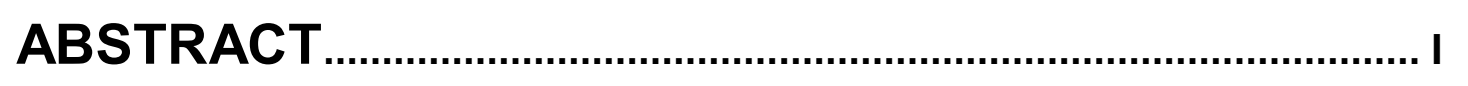

ACKNOWLEDGEMENTS ............................................................ II

TABLE OF CONTENTS ................................................................... III

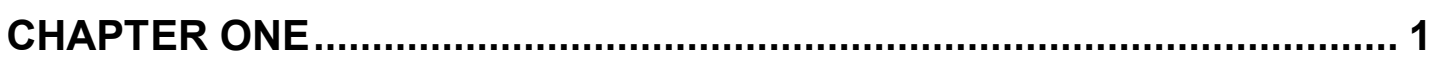

INTRODUCTION ........................................................................... 1

1.1 Background of the study .............................................................................................. 1

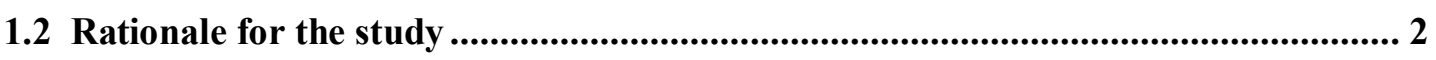

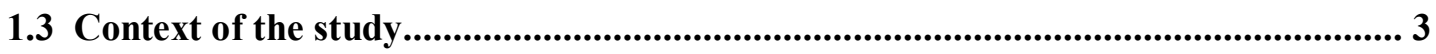

1.4 Research questions ....................................................................................................... 4

1.5 The organisation of this thesis........................................................................................... 6

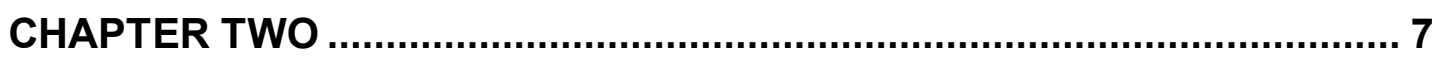

LITERATURE REVIEW ...................................................................... 7

2.1 Part 1: Introduction .......................................................................................... 7

2.1.1 The policy and cultural contexts of assessment in Aotearoa ................................ 7

2.2 The use of portfolios in early childhood settings ....................................................10

2.3 The purpose, contents and ownership of children's portfolios ..................................12

2.4 Portfolio accessibility .....................................................................................................

2.5 Portfolios a tool that supports children's learning .....................................................14

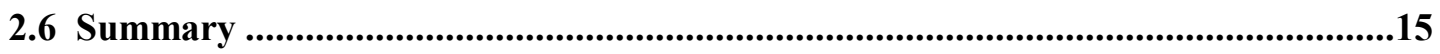

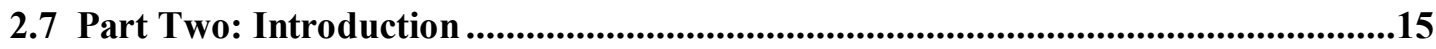

2.7.1 Moving methodologies: Teachers as researchers ................................................16

2.8 The teacher as the researcher; the complexities of the concept .................................17

2.8.1 The teacher as the researcher: current practice in Aotearoa .................................18

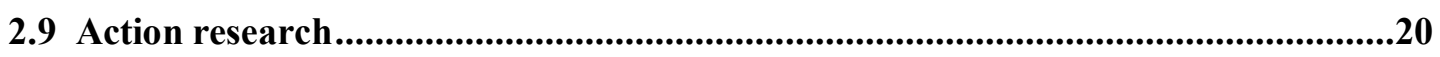

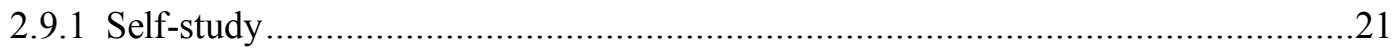

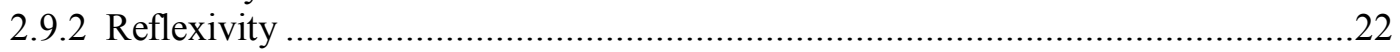

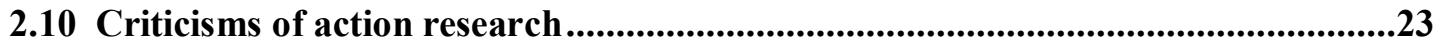

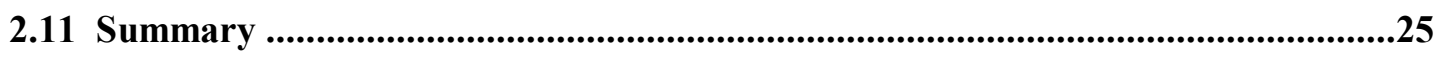




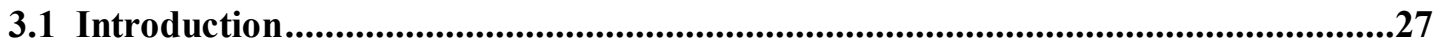

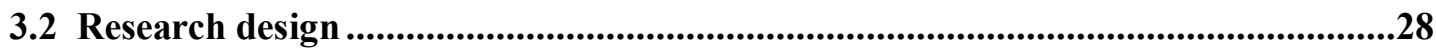

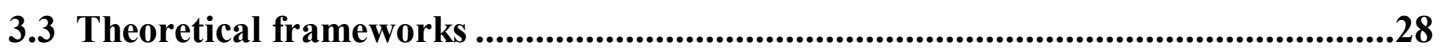

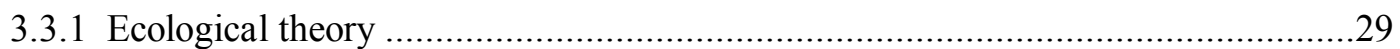

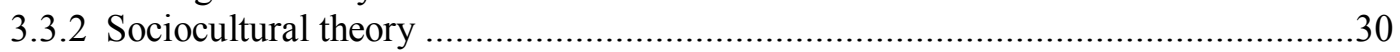

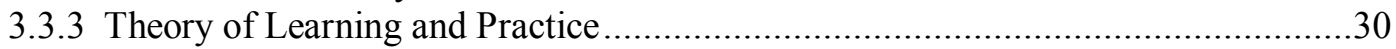

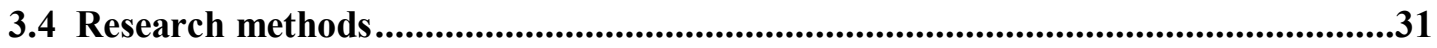

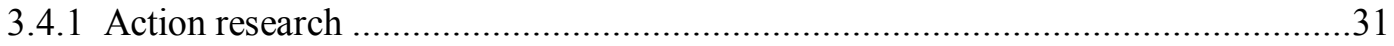

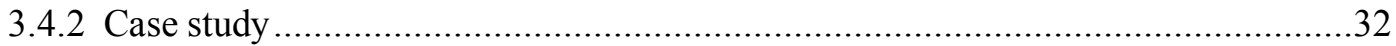

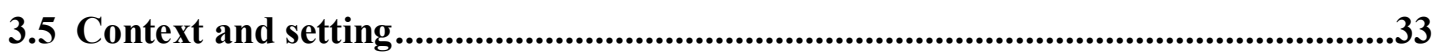

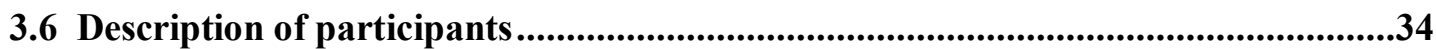

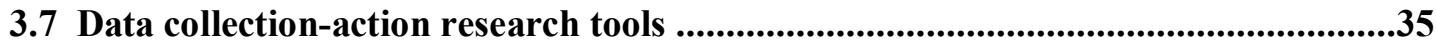

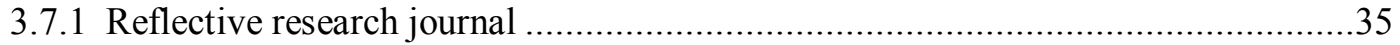

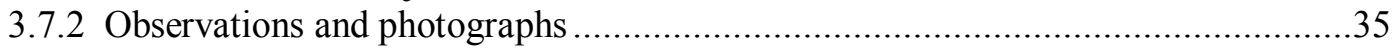

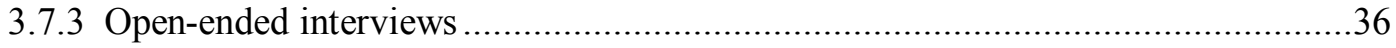

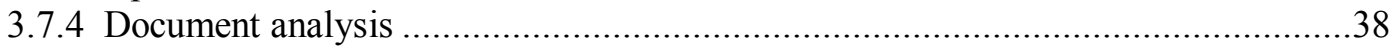

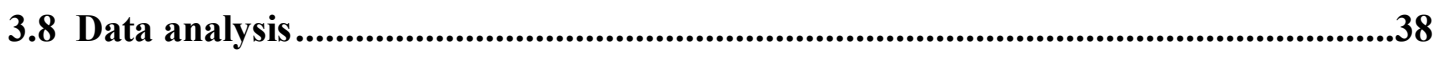

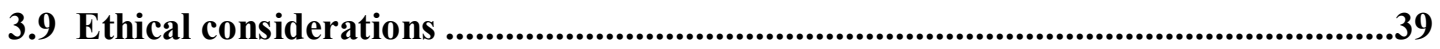

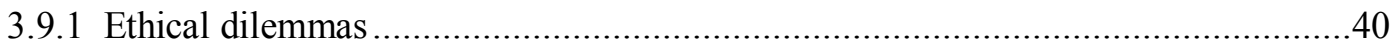

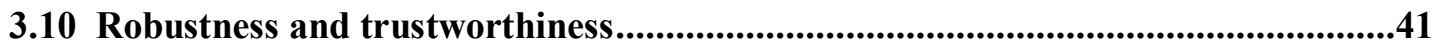

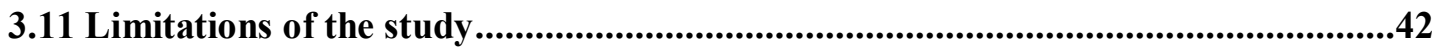

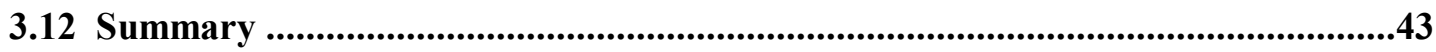

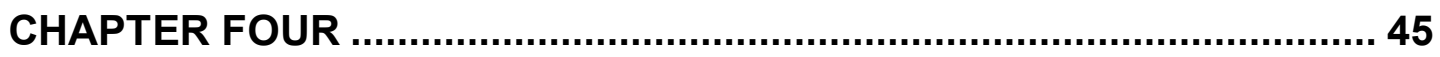

MAKING PORTFOLIOS ACCESSIBLE …........................................... 45

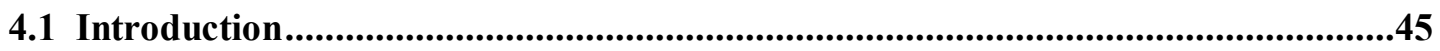

4.2 What did accessible mean in my centre? ......................................................................45

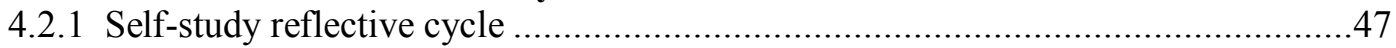

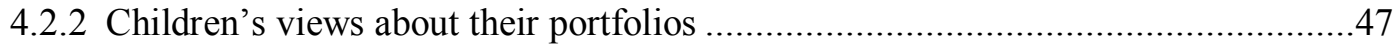

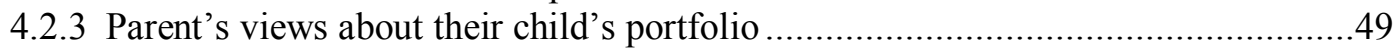

4.2.4 The children's use of portfolios at the centre and home....................................50

4.2.5 How I was using portfolios with children: the problem ....................................51

4.2.6 How my colleagues used portfolios with children ..............................................52

4.3 Making children's portfolios accessible to them: The solution ..............................54

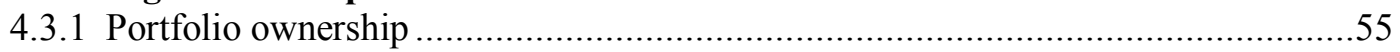

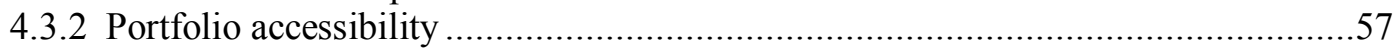

4.3.3 Children's use of portfolios: what is happening for children? .............................57 
4.4 Portfolios making a difference to teaching and learning................................................59

4.5 What does "accessible" mean in my centre ................................................................61

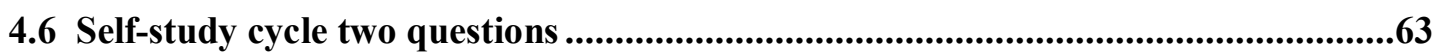

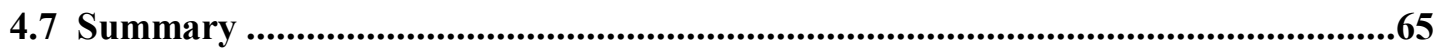

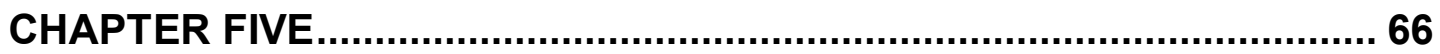

INVOLVING CHILDREN IN THE PORTFOLIO PROCESS ........................ 66

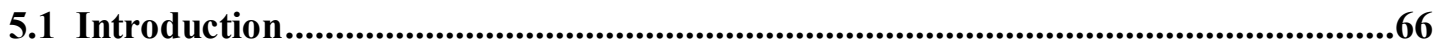

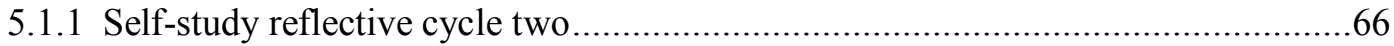

5.2 How were children contributing to their portfolio? ....................................................67

5.3 Teaching team collaboration and discussion ..........................................................71

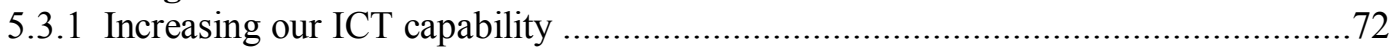

5.4 Involving children in the portfolio process: The solution.......................................73

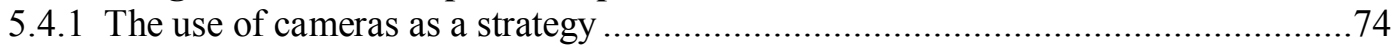

5.5 Children explore the concept of portfolio ownership .................................................75

5.6 "Portfolios are all about me" ......................................................................................76

5.7 The challenges of improving my practice ............................................................77

5.7.1 Supporting children's involvement in the portfolio process ...............................78

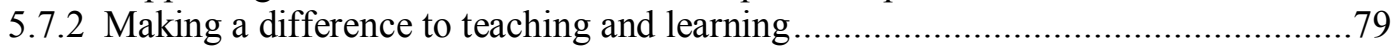

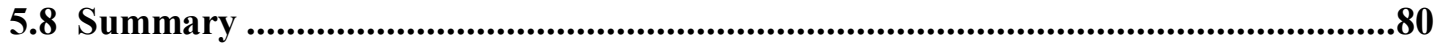

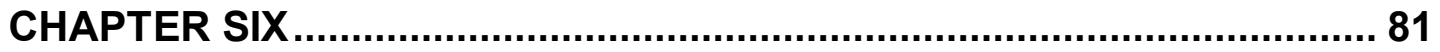

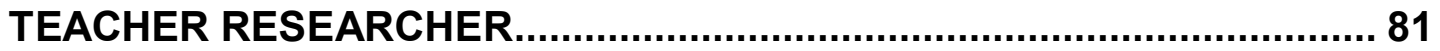

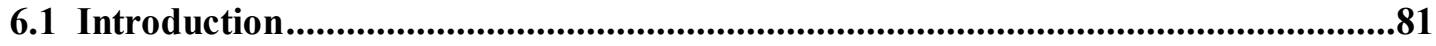

6.2 My changing role from teacher to researcher ..............................................................81

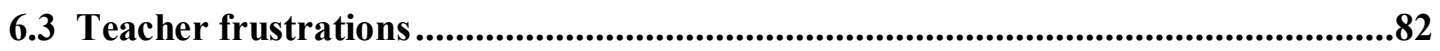

6.4 The triumphs of the teacher researcher.........................................................................84

6.5 The education review office returns..................................................................................85

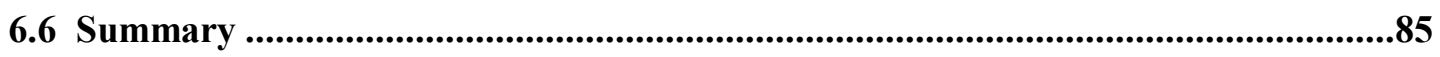

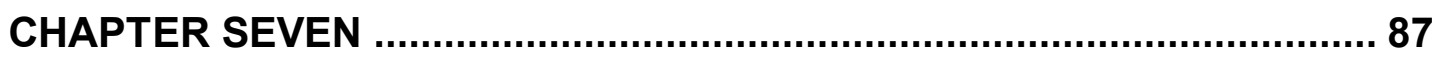

CONCLUSIONS AND FUTURE POSSIBILITIES .................................... 87

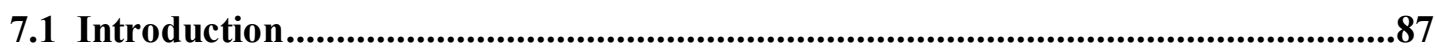


7.2 Portfolio accessibility

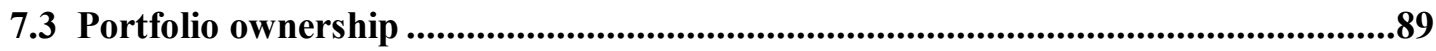

7.4 The tribulations and triumphs of the teacher researcher ......................................89

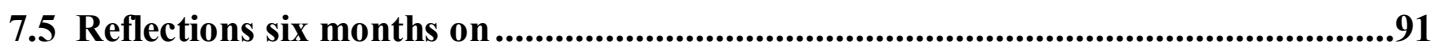

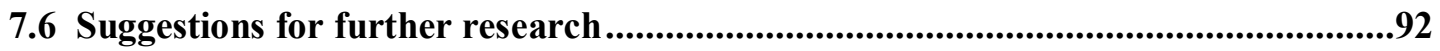

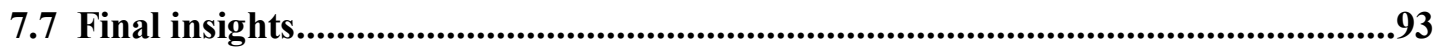

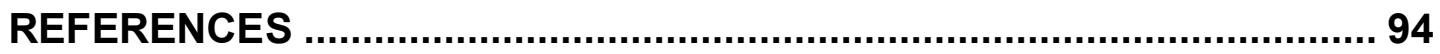

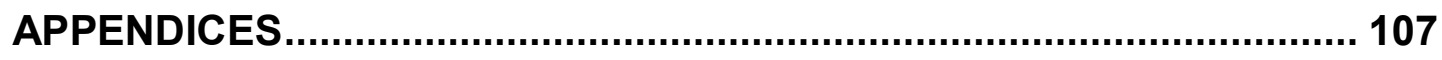

Appendix A: Research questions and methods to answer questions ...............................107

Appendix B: Research questions and methods to answer questions ............................108

Appendix C: Information sheet for Manager........................................................109

Appendix D: Consent form for Manager ................................................................................110

Appendix D: Information sheet for teachers.................................................................111

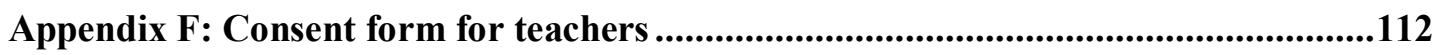

Appendix G: Information sheet for parents/whānau ...................................................113

Appendix H: Consent form for parents/whānau....................................................................114

Appendix I: Information sheet for parents of a case study child....................................115

Appendix J: Consent form for parents of a case study child .........................................116

Appendix K: Information sheet for children...........................................................117

Appendix L: Consent form for children ...........................................................................118

Appendix M: Open-ended interview schedule for teachers, children and parents ......119

Appendix N: Examples of data gathering and analysis techniques and tools ...............121

Appendix O: Portfolio introduction: the purpose and contents ......................................123 


\section{Chapter One}

\section{Introduction}

The main intention of this research was to investigate how I could improve my portfolio assessment practices as a teacher researcher by making children's portfolios accessible to the children, their parents and whānau in the centre where I worked. Some of the background issues surrounding this study will be presented in this chapter, including the significance of the development and use of children's individual assessment portfolios in early childhood care and education centres in Aotearoa/New Zealand.

\subsection{Background of the study}

The development in the 1990's of the curriculum document Te Whäriki (Ministry of Education, 1996a) set in place a new direction for Early Childhood Education in Aotearoa/New Zealand. In 1996 the final version Te Whāriki: He Whäriki Mātauranga mō ngā Mokopuna o Aotearoa: Early childhood curriculum (Ministry of Education, 1996a) was introduced. A significant feature of the document is that it emphasises sociocultural theory and the importance of planning, evaluation and assessment of individual children's learning (Ministry of Education, 1996a). Later that year another significant early childhood policy document was released: The Revised Desirable Objectives and Practices (DOPs), (Ministry of Education, 1996b) although it did not come into force until 1998. At this time, the accompanying resource Quality in Action: Te Mahi Whai Hua. Implementing the revised statement of desirable objectives and practices in New Zealand early childhood services (Ministry of Education, 1998) was introduced to support the mandatory implementation of the DOPs; both documents further emphasised the importance of assessment of children's learning (Ministry of Education, 1996b, 1998).

The use of portfolios as an assessment tool in early childhood education seemed to coincide with the release of Quality in Action (Ministry of Education, 1998). The resource promoted the use of individual children's portfolios as a method of 
assessment (Te One 2000). It also detailed the types of documentation that should be used in the compiling process and an expectation of the contents:

To celebrate children's learning achievements, educators open a file for each child. It illustrates each area of the child's life and contains examples of artwork, photographs of the child and their whānau, written observations from educators, anecdotal accounts of events in the child's life, and celebrations of the child's success. These files are available to the children, their whānau, and educators and become an essential part of planning for children's experiences within the service (Ministry of Education, 1998, p. 39).

I began my teaching career as a trained early childhood teacher in 1998; two years after Te Whāriki (Ministry of Education, 1996a) had been released. However, throughout my teacher training it became a living document (Ministry of Education, 1996a). Understanding and implementing the early childhood curriculum was part of my teacher training linking-theory to practice and becoming a reflective practitioner were an integral part of the profession. The challenge for me as a teacher was to ensure Te Whäriki (Ministry of Education, 1996a) and the DOPs (Ministry of Education, 1996b, 1998) underpinned my pedagogical practices, how I planned, evaluated, assessed and documented a quality early childhood education programme for children individually and as a group.

\subsection{Rationale for the study}

For the past eight years I have worked as a supervisor/teacher at an early childhood centre where we have been compiling and using children's individual portfolios as an integral part of the centre programme. Meisels, Liaw, Dorfman and Nelson (1995) define children's individual portfolios as:

Purposeful collections of student's work that illustrate their efforts, progress and achievements, and potentially provide a rich documentation of each child's experience throughout the year. Portfolios also make it possible for children to become involved with the process of selecting and judging the quality of their work (p. 280). 
I saw portfolios as: a method of assessing children's learning; a collection of stories and artwork (artefacts) that celebrate and honour children's contributions to their learning; and inform parents/whānau about their child's learning and progress. Although I believed that the portfolios celebrated and promoted children's learning, I realised that the crucial aspect of children's reflection on their learning, the child's voice, was missing (Carr, 2001; Clark \& Moss, 2005). This was compounded by the fact that children did not have easy access to their portfolios. I identified this as a concern in 2003, and since this time there has been ongoing discussion in my centre about making children's portfolios more accessible to them.

In March 2004 the Education Review Office (ERO) conducted a review of the centre. In their report, not having children's portfolios accessible was identified as an area for improvement. Their report stated:

Parents and children do not have easy access to children's portfolios, although they can be viewed on request. To enable children to reflect on their learning experiences it would be beneficial to have their portfolios more readily accessible (p. $5^{1}$ ).

This official identification of the issue as one that needed attention provided me with the impetus to explore ways to make portfolios freely available to children in my centre and what it means to make the portfolios accessible. The opportunity to undertake a thesis ( 3 papers) as part of the degree of Master of Education enabled me to address this concern.

\subsection{Context of the study}

In 2005 the release of the professional development resource: Kei Tua o te Pae: Assessment for learning: Early childhood Exemplars (Ministry of Education, 2004) and the exemplar inspiration day seminars (Educational Leadership Project, pers. comm. 13.8.05, 29.7.06) I attended further contributed to a significant shift in my thinking about my portfolio assessment practices and the need to improve how I evaluated, assessed and documented children's learning individually and as a group. The Exemplars are defined as:

\footnotetext{
${ }^{1}$ For ethical and confidentiality reasons this ERO report will not be included in the reference list.
} 
Exemplars are examples of assessments that make visible learning that is valued so that the learning community (children, families, whānau, teachers and others) can foster ongoing and diverse learning pathways (Ministry of Education, 2004; Book 1, p. 3, emphasis in the original).

The exemplar examples contained within the eight books that make up the Kei Tua o te Pae (Ministry of Education, 2004) are stories and narratives that are documented in children's portfolios from fifty different settings. This reflected the diversity of early childhood education throughout Aotearoa/New Zealand (Ministry of Education, 2005). The exemplars emphasise socio-cultural assessment practices, the importance of multiple voices and perspectives contributing to the assessment documentation of children's learning. The exemplars supported my arguments on portfolio accessibility as they promoted the importance of portfolios that are freely accessible to children, their parents and whānau. Kei Tua o te Pae: Assessment for learning: Early childhood Exemplars (Ministry of Education, 2004) are a powerful resource tool that can be used by teachers to enhance teacher's assessment practices and the teaching learning process (Ministry of Education, 2005; Nuttall, 2005).

The conception of my research project in 2006 coincided with the involvement of our centre in the professional development programme: Implementing Kei Tua o te Pa: Assessment for learning: Early childhood exemplars. As a team we were conducting a centre self-review focusing on how we plan for children individually and as a group and how we assess, document and make visible their learning. We were using the "Plan, Do, Study, Act" cycle from The quality journey, He haerenga whai hua (Ministry of Education, 1999) resource, the exemplars and on-going professional development to guide our review.

\subsection{Research questions}

The main objective of this study was to investigate how I could improve my practice as a teacher by making children's portfolios freely available to children, their parents and whānau in the early childhood care and education centre where I worked. I chose this focus for my research as I recognised myself as a living contradiction. My portfolio assessment practices at the time clearly suggested that I was not putting into 
practice my educational values, i.e. my belief that children's portfolios should be accessible (McNiff, 2002; Whitehead, 1988). As the researcher I am the subject of this research. I present an insider perspective that investigated my worldview on how I can improve my pedagogical practices in order to gain a deeper understanding of children's learning and my role in supporting children's learning. Therefore, this study has two parts:

-Part A: The writer as the teacher/researcher, and

-Part B: (a) Accessibility of children's portfolios and

(b) Involving children in the portfolio process

At times, the parts ran parallel, and at other times, these parts were interwoven. These issues have provided a starting point for the two sets of questions this research considered. In action cycle one I investigated:

1. How do children use portfolios?

2. What will I do to make children's portfolios accessible to them?

3. Will making children's portfolios accessible to them make a difference to teacher practices and children's learning?

4. What are the benefits of conducting action research as a means to improve my pedagogical practices?

An action research design explored research questions as they emerged. My questions in action cycle one generated the questions for action cycle two:

1. What will I do to involve children in the portfolio process?

2. Will involving children in the portfolio process make a difference to teacher practices and children's learning?

3. What are the benefits of action research as a means to improve my pedagogical practices?

I hoped that by investigating how I could improve my portfolio assessment practices a collaborative enquiry approach to teaching and learning (Wenger, 1999) would be promoted, and that this would support the improvement of the sociocultural (Vygotsky, 1978) planning and assessment practices within our centre (Meade, Ryder \& Henriod, 2004: Ministry of Education, 1996a, 19966, \& 2004). 


\subsection{The organisation of this thesis}

The literature review in Chapter Two is organised as two parts. Part one discusses the literature on the topic of using children's portfolios in early childhood settings and the arguments that surround what it means to make portfolios accessible. Part two explores the issues, arguments and debates surrounding the notion of teachers as researchers, action research and its impact on teaching practice and children's learning are also discussed. The methodology chosen and used in this research project is described in Chapter Three. Chapter Four explains the first self-study action research cycle on how I improved my practice by making portfolios accessible. The findings and the discussion of cycle one generated the questions for the second action research cycle. Chapter Five explains my role in involving children in the portfolio process, and the process of transforming my practices in order to enhance children's visibility as participants in their own assessment of their learning. Chapter Six presents my findings on the challenges, frustrations and the benefits of conducting self-study action research. Chapter Seven presents a synthesis of the findings of the action cycles and suggestions for further research. 


\section{Chapter Two \\ Literature Review}

\subsection{Part 1: Introduction}

This literature review focuses on specific topics imperative to the aims and the questions of this research. This literature review is presented in two parts because this action research study has two sections. Firstly, the accessibility of children's portfolios and involving children in the portfolio process is examined. Secondly, the writer as the teacher researcher is discussed. The literature discussed in part one focuses on the topic of using children's portfolios in early childhood settings and the issues that surround what it means to make portfolios accessible. It also investigates the involvement of children in the portfolio process. In part two, the literature discussing the teacher as the researcher is presented.

After engaging with the literature it became evident that there were four themes fundamental to the questions and aims of the research. The four themes investigated in the first section of this review are:

1. The use of portfolios in early childhood settings

2. The purpose, contents and ownership of children's portfolios

3. Portfolio accessibility

4. Portfolios as a tool that supports children's self-assessment of their learning.

The chapter begins by positioning portfolio assessment practices within the political, historical and cultural context of assessment in early childhood settings.

\subsubsection{The policy and cultural contexts of assessment in Aotearoa}

Since the educational reforms in the 1990's in both Aotearoa/New Zealand and internationally there have been ongoing educational and political debates (Austin, 1993; Carr, 1990) about the implementation of effective assessment and evaluation practices that document children's learning and progress in early childhood care and education settings (Anning, Cullen \& Fleer, 2004; Carr, May, \& Podmore, 1998). 
The overall aim of the reforms across the education sector was "to improve the quality of education for all New Zealand children" (Irving, 1990, p. 96). Issues of equity funding; regulations; accountability; accessibility; participation; curriculum development; and quality of educational experiences for children; were part of the rationale and key features of the reforms in early childhood education (Dalli, \& Te One, 2002; Irving, 1990; May, 2002).

Significant policy changes and initiatives at this time led to the development and implementation of Te Whäriki the national early childhood curriculum (Ministry of Education, 1996a); the revised DOPs (Ministry of Education, 1996b); and the development of the innovative learning and teaching stories assessment framework (Carr, May, Podmore, 1998). The reforms coincided with a shift in thinking about assessment procedures and practices (Broadfoot, 2000; Carr, 1990, 2001; Carr, May, Podmore, 1998) in early childhood education in this country (Alcock, 2000; Carr \& Cowie, 1997; Launder \& Dalli, 1997; Smith, 1998; Te One 2000, Wilks, 2000) and internationally (Edwards, Gandini \& Forman, 1998; Nutbrown, 1994).

The literature on assessment of children in early childhood care and education centres prior to the implementation of Te Whäriki (Ministry of Education, 1996a) suggests that assessment methods focused on a summative deficit approach ( Carr, 2001). This approach emphasised assessing individual children's observable skills and developmental stages underpinned by Piaget's stage theory (Anning, Cullen \& Fleer, 2004; Bredekamp, 1993; Penrose, 1993; Smith, 1998; Wilks, 1993).

In contrast, Te Whäriki (Ministry of Education, 1996a) promoted alternative ways of thinking about assessment that emphasised a formative credit based approach underpinned by ecological and sociocultural theoretical perspectives: "This curriculum emphasises the critical role of socially mediated learning and of reciprocal and responsive relationships for children with people, places, and things" (Ministry of Education, 1996a, p. 9). Part B in Te Wharriki states that:

It is essential that assessment and evaluation are based on the goals of each strand of the curriculum and that the principles of the curriculum are always applied. 
The needs of children, not assessment procedures, should determine the curriculum (p. 29).

Te Whāriki (Ministry of Education, 1996a) did not provide or include guidelines or a specific framework on how to implement effective assessment practices for assessing individual children using the principles, strands and goals (Cullen, 1996). However, Te Whäriki (Ministry of Education, 1996a) promotes an expectation that "each centre will choose their own assessment procedures (Carr, \& Cowie, 1997, p. 8). This became a significant challenge for teachers throughout the very diverse services in the early childhood sector. May and Carr (1998) point out:

Assessment and evaluation guidelines for Te Whäriki have not yet been written and in the meantime there are a wide variety of approaches being used, some of which cause the authors concern (p. 5).

May and Carr (1998) and Podmore (1998) expressed concerns about the use of inappropriate deficit assessment procedures that did not connect with the curriculum. This became "part of the "rationale" for their "involvement in research on assessment and evaluation" (May, \& Carr, p. 1). This led to the development of the learning stories and teaching stories assessment and evaluation framework as a sociocultural credit based approach. Cowie and Carr (2004) define 'learning stories' as:

\begin{abstract}
Structured narratives that track children's strengths and interests; they emphasise the aim of early childhood as the development of children's identities as competent learners in a range of different arenas. They include an analysis of the learning (a 'short term review') and a 'what next?' section. The narratives frequently include the interactions between the teacher and the learner, or between peers; often the episode is dictated by the learner as a 'child's voice' (p. 97).
\end{abstract}

The teaching stories framework focused on the evaluation of the programme in relation to Te Whäriki (Ministry of Education, 1996a) rather than a focus on the assessment of individual children. It does however connect to the learning stories assessment framework. This approach highlights the role of the teacher in the assessment of children's learning. May and Podmore (1998) describe teaching stories as a framework that: 
Create responsive, reciprocal, and respectful relationships with people, places and things. ...The framework highlights the crucial facilitating role of adults as teachers who:

- $\quad$ observe and listen to children

- $\quad$ provide a learning environment

- make connections with family and community

- $\quad$ are supported by management policies and processes (pp. 23-24).

Thus the links between curriculum; assessment; evaluation (Carr, \& May, 1993; Ministry of Education, 1993, 1996a, 1998, 2004); government policies that focused on quality; accountability and the improvement of teaching and learning provided the impetus for the development of, and increasing use of children's individual portfolios (Te One, 2000, 2002). Over the last decade the portfolios became an alternative means of teachers assessing children's learning in early childhood care and education centres (Alcock, 2000; Carr, 2001, Carr, May \& Podmore, 1998; Lauder \& Dalli, 1997).

\subsection{The use of portfolios in early childhood settings}

There is a small amount of literature in Aotearoa/ New Zealand and internationally on the use of portfolios in early childhood education centres (Alcock, 2000; Cohen, 1999; Hebert, 2001; Helm, Beneke, \& Steinheimer, 1998; Potter, 1999; Smith, 2000) Te One (2000) argues:

The concept of portfolio use in early childhood education as a research topic is "immature" (Creswell, 1995, p. 146), because there is a lack of "theory and previous research" and indeed, specifically relevant literature. The nature of portfolios and their purpose needs exploration (p. 32).

This argument provided the justification for conducting this study; in that it contributes to a body of research on the valuable process of using portfolios in an early childhood education setting. 
The use of portfolios as a method of assessment and as a tool for implementing effective assessment procedures and practices has evolved over the past decade. There has been a significant shift in thinking from portfolios being used as high stakes assessment model that contain documentation (observations) linked to curriculum objectives or children's needs and were selected by the teacher, to using portfolios as an assessment for learning (Barrett, 2005). This means portfolios have developed into tools to bring about self-awareness and meta-cognition (Hebert, 2001; Rogoff, \& Lave, 1984). Currently portfolios are used by teachers as an assessment tool that contains observations or learning stories linked to children's interests (Carr, 2001, Te One, 2000, 2002) The stories show continuity, growth and change in thinking and learning over time that teachers and children have selected (Carr, 2001; Fleet, Patterson, \& Robertson, 2006; Stefanakis, 2002, Wiener \& Cohen, 1997).

These shifts in thinking have been influenced by policy initiatives, accountability requirements and a growing body of research on pedagogical documentation (Alcock, 2000; Edwards, Gandidni, \& Forman 1998), socio-cultural theoretical perspectives (Ministry of Education, 1993, 1996a) and the development of effective assessment frameworks (Carr, 2001, Carr, May, \& Podmore, 1998). In particular, the learning and teaching stories assessment approach that supports and makes visible children's learning in early childhood education centres in Aotearoa/New Zealand (Carr, May, \& Podmore, 1998; Fleet, Patterson, \& Robertson, 2006; Lauder \& Dalli, 1997; Ministry of Education, 1998, 2004; Te One, 2000, 2002).

Hebert (2001) proposes that portfolios can be described and understood as being in different states depending on the stage of portfolio development within the setting. This includes how they are defined and used by teachers, children, parents and whanau. In their inactive stage they can be understood as a "learning repository that contains evidence of skills attained over time, topics of interest, a history of what was thought to be important and why" (p. xxi). When portfolios are in an active state they are "an ongoing and generative interaction between the collection and the collected (p. xxi) they also include many of the previous dimensions. When not used to their full potential the crucial aspect of this interaction is missing (Hebert, 2001). Te One (2000) describes portfolios as a powerful qualitative assessment tool; an 
innovative and authentic way of collecting and documenting examples of children's interests, work, achievements "and the curriculum they experience" (p. 29).

The findings of Te One's (2000) study reveal that individual child portfolios are predominantly used for evaluating and assessing the child's learning and development over time and as a communication tool. They are a means of communicating to parents the uniqueness and complexity of their child's learning. Hebert (2001) argues that portfolios "must be understood as a generative tool for expanding and describing a child's learning" ( $p$. xiv) Portfolios are used as a pedagogical tool (Alcock,. 2000; Edwards, Gandini, \& Forman, 1998) for teachers to critically reflect on their teaching and assessment practices; children's learning and their role in enhancing children's learning (Barrett, 2005; Claxton \& Carr, 2004; Stefankis, 2002; Te One, 2000, 2002).

In contrast, Dahlberg and Moss (2005) discussing the work of Fendler (2001) warn that portfolios and self-evaluation are "devices":

that can be seen as new strategies for governing the child down to his or her very own soul. More of the child's personality, emotions, creativity, capacity for empathy and co-operation are opened up for judgements and governing. ...From this perspective documentation can be viewed as a potential act of power and control, just another device for governing the child. ...or are there other means of working with documentation and portfolios which try to avoid this possibility? (p. 108).

To find out alternative ways of working with and using portfolios that deconstructs the discourse of power and control; this research aimed to critically examine and gain a deeper understanding of the importance of the purpose, contents and ownership of children's portfolios.

\subsection{The purpose, contents and ownership of children's portfolios}

The literature suggests that there is no one correct portfolio model or process. (Hebert, 2001; Helm, Beneke, \& Steinheimer, 1998; Barrett, 2005; Te One, 2000) 
The purpose, contents and ownership of children's portfolios is connected, they are inseparable "decide one and the other two will be decided as well" (Hebert, 2001, p. 44). There are three stages of portfolio ownership:

1. Teacher organised portfolios: If the purpose of the portfolio is to be used for accountability reasons the artefacts will be chosen, collected and compiled solely by the teacher; they have ownership of the portfolio.

2. Teacher and child organised portfolios: If the purpose of the portfolios is to be used for supporting, improving and assessing children's learning. The artefacts collected will tell the story of children's learning over time and include multiple perspectives the children's teachers, and parents' voices. Teachers, children and their parents will choose what goes in to the portfolio; there is negotiated control of the process; there is shared portfolio ownership

3. Child organised portfolio: If the purpose of the portfolio is to show the child's story (view) of their learning "the contents are less certain". The contents will depend on the age of the child and their understanding and involvement in the portfolio process and of the meaning of ownership; the child would be the owner (Hebert, 2001, pp. 44-49).

Current literature on the use of portfolios in early childhood highlights that over time the teacher and child organised portfolios have become the most commonly used method Hebert (2001) argues:

The recognition that the portfolio belongs to the child significantly alters the role of the teacher in portfolios decisions and introduces different ways of thinking about the assessment process (p. 46).

Therefore a crucial component of children's ownership of their portfolio is accessibility; children have the opportunity to choose, add artefacts and have easy access to their portfolio at any time (Hebert, 2001; Te One, 2000, 2002; Wiener, \& Cohen, 1997).

\subsection{Portfolio accessibility}

It is suggested that there is a lack of research (Helm et al., 1998; Ministry of Education, 2004; Smith, 2000) on the topic of making portfolios accessible to 
children and parents although Te One $(2000,2002)$ identifies this as a significant aspect of the portfolio process. The literature confirms the importance of portfolios being made accessible to children and their parents, and discusses the role of the teacher in involving children throughout the portfolios process in order to improve pedagogical practices and quality learning outcomes for children. There is very limited discussion on what "accessible" means. The literature describes accessible in terms of:

1. Physical accessibility, portfolios being available at any time for children and their parents to look at, to read.

2. Intellectual accessibility, portfolios are comprehensible to children and parents as they contain both words and photographs, so children have the opportunity to reflect on their previous documented experiences or stories (Barrett, 2005; Cohen, 1999; Potter, 1999; Smith, 2000; Te One, 2000, 2002).

Reflection is a significant aspect of what it means to make portfolios accessible. As Barrett (2005) argues "a critical component of an educational portfolio is the learner's reflection on the individual piece of work (often called artefacts) as well as an overall reflection on the story that the portfolio tells" (p.2).

\subsection{Portfolios a tool that supports children's learning}

A recurring theme in the literature is the potential of portfolios for promoting children's reflection, and self-assessment (Helm, Beneke, \& Steinheimer, 1998), when children contribute to compiling and sharing their portfolios with teachers and their peers on a frequent basis (Smith, 2000). Teachers need to really listen to children to develop an understanding of what is important and valuable learning for them, their parents and whānau (Cohen, 1999; Potter, 1999; Te One, 2000, 2002). Smith's (2000) research on children's use of portfolios as a reflective tool further supports this argument

Six months ago I did not expect to hear preschoolers holding conversations about their accomplishments, nor did I expect to hear them discuss growth, plans and goals. I was surprised to see young children take charge of their own evaluations (p. 208). 
Making portfolios physically and intellectually accessible (Carr, 2001) and active (Hebert, 2001) emphasises involving children in the portfolio process as means to support children's thinking about their learning (metacognition), (Rogoff \& Lave, 1984). "The impact of the portfolio upon metacognitive development may be the most significant development" (Hebert, 2001, p. 132). Children need the time and the opportunity to revisit and reflect on their previous learning. Teachers need to use effective practices that "notice, recognise and respond" (Ministry of Education, 2004, book 1, p. 4) to children's learning so they become competent and confident learners involved in the assessment of their learning (Ministry of Education, 1996a).

\subsection{Summary}

The literature (Cohen, 1999, Hebert, 2001; Hebert, 2001; Helm, Beneke, \& Steinheimer 1998; Potter 1999; Smith 2000; Te One 2000, 2002), strongly confirms the need for children's portfolios to be made accessible to children and their parents, and discusses the role of the teacher in involving children throughout the portfolio process in order to improve pedagogical practices and quality learning outcomes for children. These arguments provided the justification for conducting research as a teacher researcher on ways of making portfolios more accessible for children and parents in my centre.

\subsection{Part Two: Introduction}

The literature explored in the second part of this chapter focuses on the issues, arguments and debates surrounding the notion of teachers as researchers, action research and its impact on teaching practices and children's learning. The four main themes central to the aims and the questions of this section are:

1. The teacher as researcher and the complexities of the concept

2. Action research methodology and how it has transformed over time

3. Self-study and reflexivity in action research

4. Criticisms of action research; the significant pitfalls for the teacher and how these can be avoided 


\subsubsection{Moving methodologies: Teachers as researchers}

Over the past decade in Aotearoa/New Zealand and internationally there have been significant shifts in educational research. At the beginning of the decade research on teacher's practices were being predominately examined by professional researchers (Brostrom, \& Vilien, 1998; Kincheleo, 2003). The growth of the teacher researcher movement (Elliot, 1991) led to professional researchers working collaboratively undertaking and co-constructing research on teaching practices (Meade, Ryder \& Henriod, 2004; Stenhouse, 1986). This was characterised by a move towards teachers conducting research on their pedagogical practices as a means to improve their practices and this allowed teachers to gain a deeper understanding of how the teacher as researcher influences children's learning (David, 1998; Kondoyianni, $1998 \mathrm{Mc}$ Taggart, 1991; Mac Naughton, \& Siraj-Blatchford 2001; 2004; Mutch, 2005).

The importance of the teacher as the researcher has become a significant issue in education research (Burns, 1991; Elliot, 1991; Stenhouse, 1986). There is now an expectation that teachers will conduct research projects in order to systematically critique and transform their pedagogical practices (Whitehead \& McNiff, 2006) therefore becoming producers as well as consumers of research (Goodfellow, 2005; Rodd, 2005). According to Mutch (2005):

Educational research particularly school and centrebased research, has received a lot of press lately. Teachers at all level are expected to undertake research to improve their teaching practices or to make use of the published research to improve student's learning (p. 7).

The expectation that early childhood teachers will conduct research has been influenced by teacher education (undergraduate and post graduate) and professional development courses (Cameron, 2007; Mitchell \& Cubey, 2003). A component of these includes students or teachers conducting small scale research investigations. These programmes emphasise conducting a systematic and critical enquiry that connects theory to practice; teacher reflection and being able to articulate ones practice (Farquhar, 2003; Mitchell \& Brooking, 2007). Rodd (2005) challenges early childhood teachers to: 
Understand and apply the findings to early childhood services, and the ability to design and implement a research project within a service. Research especially action research, is considered to be one of the most effective ways to optimise the care and education of young children (p. 199).

Action research is a methodology that has been used in educational research throughout the century that seems to have grown in popularity: "action research in the last half of the century has become a phenomenon that is paradoxically simple but complex" (Cardno, 2003, p. vii). It is a research method that is used by teachers conducting research on improving their professional practice as Kemmis and McTaggart (1988) argue:

Action research is a form of collective self-reflective inquiry undertaken by participants in social situations in order to improve the rationality and justice of their social or educational practices, as well as their understanding of these practices and the situations in which these practices are carried out (p. 5).

\title{
2.8 The teacher as the researcher; the complexities of the concept
}

The literature (Cardno, 2003; Carr \& Kemmis, 1993; Dyck, 2002; Johnston 1994; Kincheleo 2003; Mutch 2005; Newman 1998; Whitehead \& McNiff, 2006) suggests that the concept of teacher as the researcher includes a teacher at any level of the education system conducting educational research to improve their pedagogical practices, and to improve quality learning outcomes for children:

\begin{abstract}
When a practitioner becomes a researcher into his (sic) own practice, he engages in a continuing process of self-education. ...When he functions as a teacherresearcher-in-practice, the practice itself is a source of renewal. The recognition of error with its resulting uncertainty, can become a source of discovery rather than an occasion for self-defense (Schön, 2003 p. 299).
\end{abstract}

This view of the teacher as researcher emphasises teachers as learners, who critically reflect on their own practice, and have knowledge of the theories, and theoretical perspectives that underpin their pedagogical practice as defined by Kincheleo (2003): 
Teachers are viewed as learners-not as functionaries who follow top-down orders without question. Teachers are seen as researchers and knowledge workers (sic) who reflect on their professional needs and current understandings. They are aware of the complexity of the educational process and how schooling cannot be understood outside of the social, historical, philosophical, cultural, economic, political and psychological contexts that shape it (p. 18).

Kincheleo's argument focuses on teachers and schools in the formal education system, but they apply equally to the early childhood sector in Aotearoa/New Zealand as well as internationally. The importance of critical reflection, selfevaluation and reflective action are significant characteristics of the teacher as researcher (McNiff \& Whitehead, 2005; Schön, 2003; Stenhouse, 1996). These are the tools needed to conduct effective and successful action research (Hatton \& Smith 1995; Mac Naughton, 2001; Mac Naughton, \& Rolfe, 2001; Mutch, 2005).

Parallel views of the meaning of teacher as the researcher have emerged in the literature. These include the notion of the inquiring teacher approach; the teacher-asresearcher movement; narrative inquiry; teachers' stories; self-study of practice; the discipline of noticing and problem-based methodology (Jalongo \& Isenberg 1995, Johnston 1994, Mason 2002, Robinson 1993). The literature identified the significance of critical reflection as an important characteristic in all of these views; although there are similarities in how critical reflection is used and defined, there are also differences. The underlying argument of these approaches is that they are more practical for teachers to use as ways of exploring the improvement of their pedagogical practices or as part of action research (Jalongo \& Isenberg 1995, Johnston 1994, Robinson 1993).

\subsubsection{The teacher as the researcher: current practice in Aotearoa}

Clearly the concept of the teacher as researcher is not a simple one to define; there are multiple ways that this concept has developed. This section will illustrate that in Aotearoa/New Zealand these variable views are currently evident in early childhood education research and practice. 
One example, in the early childhood curriculum Te Whāriki: He Whāriki Mātauranga mō ngā Mokopuna o Aotearoa (Ministry of Education, 1996a) emphasised the importance of the critically reflective teacher for quality practices. This is evident in the reflective questions that are provided in the document aimed at promoting collaborative discussion and critical reflection on teaching practices and quality learning outcomes for children. "Examples of reflective questions designed specifically for each goal provide a further basis for discussion" (p. 10).

The Quality Journey: He Haerenga Whai Hua (Ministry of Education, 1999) was developed as a framework for teachers to critically evaluate and establish quality improvement systems by way of a self-review approach and "includes a tool for measuring teaching learning and development practices" (p. 4). This tool known as the "Plan-do-study-act cycle (PDSA)" (p. 16) is similar to the cycles within the action research process that will be discussed in more detail in the action research section of this review.

The Best Evidence Synthesis Report: Characteristics of professional development linked to enhanced pedagogy and children's learning in early childhood settings (Mitchell \& Cubey, 2003) provides further evidence of the importance of critical inquiry and critical self-reflection by teachers conducting their own individual action research. Alternatively, a collaborative approach with a professional development advisor providing the on-going support improvement of their pedagogical practices is also discussed.

Pathways to the Future: Nga Huarahi Arataki: a ten year strategic plan for early childhood education (Ministry of Education, 2002) extends the previous discussion and research arguments, particularly the importance of critical practitioner reflection and the expectation that teachers will conduct action research to improve their teaching practices and children's learning. The goal of "improve quality of ECE services" suggests as a strategy that the "establishment of and reflection on quality practices in teaching and learning" is essential. (p. 15).

Within this strategy was the government's commitment to the establishment of six centres of innovation (COI's) focusing on effective and quality teaching practices by 
teachers in collaboration with researchers using action research and dissemination. As Meade (2004), the programme co-ordinator for the COI's programme suggests that:

The COIs will demonstrate to their peers and the community the way they use inquiry and dialogue to improve pedagogical practices. COIs will show from a research base the benefits of their teaching practices for learning by children, families, and whanau, and amongst themselves (p. 2).

The literature reviewed on the concept of teachers as researchers clearly identifies that a practical way for teachers to critically examine and explore the improvement of their pedagogical practices is by conducting one's own action research; research that follows a systematic and critical inquiry. Goodfellow's (2005) study highlights that by engaging in action research it opens up the possibility for teachers to develop an increased "sense of empowerment gained through greater insights into their own professional knowledge". This leads to an "increased capacity to work more effectively with children, and their increased ability to communicate more professionally and effectively with parents" (p. 48) an intention for this study.

\subsection{Action research}

Action research has had a long history beginning at the turn of the $20^{\text {th }}$ century although it was then referred to as educational enquiry. Kurt Lewin (1940) is "widely acknowledged as the father of the action research and the action research movement" (Cardno, 2003, p.27, \& McTaggart, 1991, p. 6). Lewin's model of the action research process is the most popular model cited in the literature, a cyclic sequence that involves the spiralling and repeated cycles of planning, acting, observing. Burns (1991) discusses how “Lewin's model is an excellent basis for starting to think about what action research involves" (p. 254).

There are a number of characteristics that are significant about action research and the research process; Kemmis and Mc Taggart (1988) propose that there are 17 key points to action research. The seven key characteristics that I have identified in the literature and used throughout this research project include 
1. Action research is an approach to improving education through change and learning from the changes; it's a political process.

2. Action research is participatory the focus is on the improvement of teachers own practices.

3. Action research is collaborative; it involves those responsible for action in improving it and those who are affected by the practices concerned.

4. Action research establishes self-critical communities of learners participating and collaborating in the process.

5. Action research is a systematic and deliberate process

6. Action research involves theorizing about one's pedagogical practices.

7. Action research involves a spiral of self-reflective cycles of; planning a change; acting and observing the process and the consequences; re-planning; acting and observing; reflecting and so on (pp. 21-25).

Since the 1940's various action research models and interpretations have been developed based on Lewin's model (Burns, 1991; Carr, \& Kemmis, 1993; Cardno, 2003; Kemmis \& McTaggart, 1988; McNiff, 2002; Meade, 2005; Mutch, 2005; Whitehead, 1998). McNiff and Whitehead (2005) argue that the critical aspect of these models is that action research "focuses on how and why teachers can improve practices". They also argue "it is also vital so show how action research generates new theory" (p. 3).

Whitehead (1988) further develops this argument and suggests what distinguishes his action research interpretation from other traditional action research approaches is "through its inclusion of I as a living contradiction within the presentation of a claim to educational knowledge" (p. 43). This aspect of action research strongly supports the concepts of the teacher as the researcher and the importance of self-study. These are a significant part of this action research study.

\subsubsection{Self-study}

Whitehead and McNiff (2006) describe self-study as a component of action research:

Practitioners investigate their own practice, observe, describe and explain what they are doing in company of one another, and produce their own explanations for 
why they are doing it. ...The theories they generate are their own theories, and they constantly test these theories against crucial responses of others to see if they can withstand criticism, in other words have validity (p. 13).

Herr and Anderson (2005) provide a similar description of self-study; "a focus on one's own personal and professional selves is a form of action research usually called self-study (Bullough \& Pinnegar, 2001) or autoethnography" (Bochner \& Ellis, 2002; Reed-Danahay, 1997) ( $\mathrm{p}$ 25). However there is a difference as Herr and Anderson refer to self-study as a form of action research rather than as a component of action research. They also refer to self-study as "insider" research; the researcher who is also the teacher is studying their own self and their practice and "is committed to the success of the actions under study" (p. 33). Therefore, they argue that it is important to acknowledge and state one's "positionality" or "multiple positionalities":

We suggest that our obligation as researchers is to interrogate our multiple personalities in relationship to the question under study. Our sense that, in making explicit the tensions we experience as researchers in our varying roles and statuses, we have the possibility of crafting uniquely complex understandings of the research question. In addition we hope to avoid the blind spots that come with unexamined beliefs (p. 44)

Therefore, the idea of reflexive understanding, and applying the concept of "reflexivity is central to action research because the researchers are also the participants and practitioners in the action research" (Cohen, Manion, Morrison 2000, p. 239).

\subsubsection{Reflexivity}

It seems that the idea of being reflexive is a deeper level of self-conscious reflection or awareness of how one's multiple positionalities impact on the research process. Cohen, Manion and Morrison (2000) define reflexivity as:

A self-conscious awareness of the effects that the participants-as-practitioners-and researchers are having on the research process, how their values, attitudes, perceptions, actions, feelings, etc are feeding into the situation being studied. ...The participants-as- 
practitioners-and researchers need to apply to themselves the same critical scrutiny that they are applying to others and the research (p. 239).

Quicke (2000) suggest that notion of reflexivity is process that is dynamic. It includes deeply reflecting on one's self and the learning institution. Quicke defines reflexivity as:

The process whereby individuals, groups, and organizations, 'turnaround' upon themselves, critically examine their rationale and, if necessary, deliberately reorder or reinvent their identities and structures. It is now necessary to do this in a more regular and selfconscious way than previously because of the sudden and often quite dramatic changes which occur in present-day society (pp.299-300).

These definitions highlight the complexity of the participant-as-teacher-and researcher and the action research process. The previous sections have described many of the strengths of action research, in particular self-study. The concluding section of the review will provide a discussion on the criticisms of action research.

\subsection{Criticisms of action research}

A provocative and significant criticism of action research by Johnston (1994) is that teachers do not usually of their own accord undertake action research; there is always an external motivation such as course or accountability requirements (Johnston, 1994; McTaggart, 1991). In contrast McNiff and Whitehead (2005) argue:

We believe that teachers are best placed to make professional judgements about evaluating and improving their work. Teachers can, and should ask, how do I improve what I am doing? And demonstrate that they know what they are doing, why they are doing it, and for what purpose (p. 3).

The analysis of the literature identifies the growing expectation that early childhood teachers should engage in research as "early childhood practitioners need to understand research processes and become more active in their own early childhood community" (Rodd, 2005, p. 199). Rodd also argues that although teachers should be engaging in their own action research there is a significant gap or lack of teachers 
who are undertaking action research and reporting their findings to their community and the wider profession.

This argument is consistent with the findings of Goodfellow's (2005) study that shows only a small number of published research articles in the Australian Journal of Early childhood over the past five years (2000-2004) "involved early childhood practitioners as researchers" (p. 48). This journal publishes research articles submitted by Australian and New Zealand authors. Of the 93 research articles that were published seven of the articles involved early childhood teachers working collaboratively on research projects that were initiated and led by university researchers. There was only one study by Ingram (2000) that "the researcher and initiator of the research identified as an early childhood teacher, it is possible that this teacher is also associated with a university" (p.51). The findings of the study reveal four significant reasons why teacher researchers do not conduct their own action research these include:

- the capacity of participants to reflect on interactions and practices (Ryan, Ochsner \& Genishi, 2001);

- the lack of familiarity of participants with research processes and methodologies and uncertainty about how to translate research findings into everyday practices (McCrystal, 2000);

- the often-needed requirement to have someone with 'research expertise' as a facilitator; and

- time and motivation on the part of participants (Goodfellow, 2000, p. 52).

Gregson (2004) suggests that it is not easy to be a teacher and researcher at the same time. It can be difficult maintaining ones energy, motivation and enthusiasm. A significant issue that may arise could include what is implemented to bring about change in the first research cycle may bring about unexpected findings. As the action research process aims to improve and transform my practice, throughout this study I have been genuinely open to the possibilities of what might emerge. These unexpected findings (see chapters; $3,5, \& 6$ ) have lead to important insights and are a valuable component of this study. 
Action research is not always seen as a legitimate form of research and it "has gained a reputation in some arenas as a messy and weak form of research because it is has been practised without appropriate rigour" (Cardno, 2003, p. vii). The validity of the action research process needs to be considered by teachers conducting action research as the results of the research are context specific, difficult to replicate, and this in turn raises questions about the generalisability and reliability of the findings.

McNiff and Whitehead (2005) argue that action research cannot be generalised or replicated, however, by producing validated evidence and making one's work available to critical scrutiny and critique, the researcher will legitamise one's claims to knowledge. To ensure validity of the research findings the collection of data requires the researcher to use multiple methods, a process known as "triangulation" a process that is used in this study (Anderson, 1998, p. 131).

\subsection{Summary}

The concept of teachers as researchers is complex as there are multiple perspectives on defining the concept. A critical factor that needs to be considered when conducting self-study action research is the importance of understanding the theory and the theoretical underpinnings of the concept of teachers as researchers, pedagogical practice, action research and the research process. The multiple role of the participant-teacher-researcher is challenging and demanding on one's time and energy. However, as this study demonstrates, it can be highly rewarding to critically examine and transform one's pedagogical practices and learning, becoming a producer, as well as a consumer of research.

The importance of critical enquiry and critical reflection is a recurring theme that has underpinned all of the sections of this review. The analysis of the literature on self study and action research highlights that reflexivity is a crucial aspect of self study and the research process (Cohen et al., 2000; Quicke, 2000)

Current writing on action research highlight that it is more than just a form of professional development. It should be seen as a legitimate form of research that generates educational knowledge and theory. A crucial aim of action research is to 
generate new theory (Herr \& Anderson, 2005; Whitehead, \& McNiff, 2006). These issues are further explored in the following chapter that outlines the research design, the research methods used, and the theoretical frameworks that have informed and guided this research study. 


\section{Chapter Three}

\section{Methods}

\subsection{Introduction}

This study used case study and action research methods to examine how to improve my teaching practices through making portfolios accessible to children, their parents and whānau in the early childhood care and education centre where I worked as the supervisor/teacher. The two action research cycles were conducted over a 12 month period. In the first action cycle this study investigated the writer as the teacher/researcher in relation to the accessibility of children's portfolios. In the second action cycle both the accessibility of children's portfolios and involving children in the portfolio process were observed.

There were two sets of research questions (see Appendix A \& B) for each self-study action research cycle. The questions for the first action cycle were:

1. How do children use portfolios?

2. What will I do to make children's portfolios accessible to them?

3. Will making children's portfolios accessible to them make a difference to teacher practices and children's learning?

4. What are the benefits of conducting action research as a means to improve my pedagogical practices? (Appendix A).

During cycle one the research questions emerged for cycle two. These were:

1. What will I do to involve children in the portfolio process?

2. Will involving children in the portfolio process make a difference to teacher practices and children's learning?

3. What are the benefits of conducting action research as a means to improve my pedagogical practices? (Appendix B).

The first section in this chapter outlines the research design and the research methods used in this study. I justify why I selected a mixed methodology of action research 
and case study to explore how to improve my practice and enhance children's learning by making portfolios freely available. This is followed by a section which discusses the context and setting of where the research was conducted and the research participants who chose to be involved in my research (it is important to note I was not doing research on them and did not see them as the data) (McNff, \& Whitehead, 2005). The third section describes the data collection; the action research tools used; data analysis and ethical considerations and dilemmas. The chapter concludes with a discussion on the issue of robustness and trustworthiness of this action research study.

\subsection{Research design}

Qualitative research aims to uncover the lived reality or constructed meanings of the research participants (Mutch, 205, p. 43).

This research study explored the process of making portfolios accessible for children and parents through discussion, reflection and observation in a natural setting (Bogden, \& Biklen, 1992: Denzin \& Lincoln, 1995: Mutch, 2005). It was open-ended in nature therefore a qualitative research design was the most appropriate in order to; present my world view and offer an insider perspective on the research process (McNiff, \& Whitehead, 2005), as well as to include the experiences and conversations of the teachers, children and their parents on the process of making the portfolios freely available to them. Denzin and Lincoln (1995) suggest

Qualitative research is multimethod in focus involving an interpretive, naturalistic approach to its subject matter. This means that qualitative researchers study things in their natural settings, attempting to make sense of, or interpret, phenomena, in terms of the meaning people bring to them (p. 2).

\subsection{Theoretical frameworks}

For this study three theories, ecological (Bronfonbrenner, 1979) sociocultural (Vygotsky 1978), and Donald Schön's (1983) theory of learning and practice have informed and guided my work. This mix of theoretical frameworks has provided me 
with some useful insights on ways of examining and improving my assessment practices, using portfolios with children and understanding children's views on their portfolios. They have also been useful for analysing and making sense of my data. Understanding theories is a crucial component of the research process as they provide explanations. LeCompte and Preissle (1993) (as cited in Mutch, 2005, p. 56) point out

Theories are statements about how things are connected. Their purpose is to explain why things happen as they do. Theories vary in size, density, abstractness, completeness and quality (p. 118).

The following is a brief description of the importance and relevance of these theories in relation to the topic, strengthening my arguments, explanations and validating the findings of this study (Mac Naughton, 2001; Mutch, 2005).

\subsubsection{Ecological theory}

Ecological theory largely based on the work by Urie Bronfenbrenner (1979) provides a social constructivist theoretical perspective that emphasises the importance of studying the ecological context of the settings that impact on children's development. Ecological perspectives highlight the influences of society, culture, relationships and the curriculum on children's learning and teaching practices (Carr \& May, 1993; Smith, 1998).

Bronfenbrenner's (1979) ecological framework underpins and is included within the early childhood curriculum document Te Whāriki (Ministry of Education, 1996a). It discusses a key aspect of learning that is of particular relevance to this study, "developing skills in using cultural tools such as ... reading writing and technology" (p. 19) by the community of learners within early childhood settings. Ecological theoretical perspectives are comparable with Lev Vygotsky's (1978) sociocultural theory (Carr \& May, 1993; Ministry of Education, 1996a; Mutch, 2005; Smith, 1992, 1998). 


\subsubsection{Sociocultural theory}

Sociocultural theory is based on the work of Lev Vygotsky (1978). He is one of the most cited educational theorists (Mutch, 2005). This theory emphasises how the social context and the teachers' interactions with children influences their construction of knowledge. This perspective provides an understanding of the complexity of children's thinking and learning (Bodrova \& Leong, 2007).

Vygotsky believed "that the purpose of learning, development, and teaching is more than acquiring and transmitting a body of knowledge; it involves the acquisition of tools"(Bodrova \& Leong, 2007, p. 16). The importance of the acquisition of tools both mental and physical is of theoretical value to this study. Sociocultural perspectives emphasise the importance of teachers critically reflecting on their own practices and having an understanding of how their pedagogical practices can enhance or suppress children's learning and development as Smith (1996) argues:

There is a need for a pedagogy which acknowledges the awesome power of the teacher in affecting children's development and an understanding that if teachers observe children, understand their cultural framework, develop close relationships with them, and formally interact with them over planned activities allowing active participation of the child, they need to take advantage of every opportunity to support learning, then there will be fewer missed opportunities and more potential for positive change (p. 62).

\subsubsection{Theory of Learning and Practice}

Donald Schön's (1983) theory of learning and practice and the notion of reflection in action are of significant relevance to the concepts of the teacher as researcher, action research and the self-study model used in this study (Cardno, 2003; Johnston, 1994; Kincheleo, 2003; Mc Taggart, 1991; Whitehead \& McNiff, 2006).

Schön's theoretical perspective of the reflective practitioner in particular the concept of reflection on action contributes to an understanding of the theory and practice of learning. Hatton and Smith (1995) describe Schön's $(1983,1987)$ concept of reflection in action as a process that "involves simultaneous reflecting and doing, 
implying that the professional has reached a stage of competence" (p. 61) in comparison to other types of reflection that involve looking back and reflecting on action some time after it has happened. Schön's theory of learning and practice suggests that professional competence plays a part in a teacher's depth of critical reflection and reflective practice, in order to improve their pedagogical practices (Schön, 2003) which are a critical component of the action research process and the credibility of this study.

\subsection{Research methods}

A mixed methodology of action research (McNiff; 2002; McNiff \& Whitehead, 2005), and case study (Merriam, 1988; Yin, 2003) were chosen for this study; as they are approaches that are deliberate, systematic and robust.

\subsubsection{Action research}

The most appropriate method to explore how to improve my teaching practices and to improve quality learning outcomes for children was through action research as defined by Carr and Kemmis (1993):

Educational action research engages, extends and transforms the self-understandings of practitioners by involving them in the research process. ...Action research is research into practice, by practitioners, for practitioners. ...Action research thus contrasts with research into practice from the outside, as it were by the generation of theoretical principles to be used by the practitioners as externally validated guides to their practice (pp. 237-238).

A significant component of this research focused on me as the teacher researcher, recognising my practice in using portfolios to date suggested to me that I was not acting out my education values in practice, i.e. my belief that children's portfolios should be accessible to them, their family and whānau (Whitehead, 1998). There are several key action research methods the most appropriate for this project was an action research self-study approach defined by Whitehead (2006) as:

In a living educational theory approach to practitioner research and a human existence, individuals hold their lives to account by producing explanations of their 
educational influence in their own learning in enquires of the kind, 'How am I improving what I am doing?' They do this in contexts where they are seeking to live the values they use to give life meaning and purpose as fully as they can (para. 1).

This is because I used the following action research self-study reflective cycles (McNiff, 2002) consisting of the following stages:

Identify an area to be investigated

Imagine a solution

Implement the solution

Evaluate the solution

Change practice in light of the evaluation

From this data new questions would emerge this cycle would then turn into new cycles (p. 11).

\subsubsection{Case study}

Merriam (1998) defines a case study as

An examination of a specific phenomenon such as a program, an event, a person, a process, an institution or a social group. The bounded system or case might be selected because it is an instance of some concern, issue, or hypothesis (pp. 9-10).

A case study method was chosen for a number of reasons. I used a single case study approach; to conduct an exploration of how I improved my teaching practices and my learning "over time through detailed, in-depth data collection involving multiple sources of information (reflective journal, observations, photographs, document analysis) rich in context" (Creswell, 1998, p. 61). My original intention for this study was to use a case study approach to study in depth three children's portfolios. However, it was not ethical of me to choose and single out three children, this did not reflect the centre philosophy of inclusive practices.

There are a number of significant characteristics and advantages of a case study method that are congruent with an action research approach, and are relevant to this research study: 
- A case study can be conducted by a single researcher who is "integrally involved in the case" (Cohen, Manion \& Morrison, 2000, p.182)

- A strength of case study is the focus on reality and action: "they begin in a world of action and contribute to it. There insights may be directly interpreted and put to use" (p.184).

- In action research I am the researcher researching my practices. The focus of the action is on changing and improving my practice. I am "taking action in two domains, action in the world-the social world 'out there' ", and "action" in my "personal world of learning-the mental world in here" (McNiff \& Whitehead, 2005, p.30).

- In action research, action and reflection are cyclical: "One cycle transforms into the next as learning informs action, action informs new learning” (Whitehead \& Mc Niff, 2006, p.66).

\subsection{Context and setting}

This action research study was conducted where I worked as a supervisor/teacher in a Preschool care and education centre attached to a tertiary institution. I was fortunate to be part of a wider community of learners (Wenger, 1999) that were committed to high quality education for all. The centre provided full time and part time care for thirty four children aged three to five years. It is licensed for twenty five children at any one time attending the centre. Four trained and registered female teachers (myself included), worked fulltime at the centre. Two centre-based teacher trainees worked part time; one was in her second year and worked one day per week; the other was in her third year and worked two days per week.

The centre is located in a colonial villa. The internal environment is divided into two main play and learning rooms; an art room and dining area; that is also used as a play and learning area; a book corner; a kitchen and the teachers' office. The outside area: is a large half-concrete and half-bark chipped space with a couple of old big trees that cast welcome shade during the long summer afternoons.

There are two equipment sheds. One is 'teacher-only access' for safety reasons, and the other is the children's shed, to which there is free access to equipment. This 
offers children choices as well as independent learning opportunities. On the concrete area there is a carpentry table; one large and one smaller sandpit area; one is under cover and one is in the open. There is a swing frame with an assortment of swings beside a garden area. On the bark chipped area there is a large fort complex with a slide and a firepersons pole. Four climbing frames to which moveable planks and ladders can be attached provide the structure for the challenge courses. There are two moveable troughs that are used for either water play or messy play.

As the centre is one of three centres located together the outdoor areas of the other two can be viewed. The follow-on nature of the centres from the under two's; to over two's then to our centre when children are aged 3-4 years creates an extended family or whanau atmosphere. This means that most of the children have known each other since they were very young and they are well accustomed to the daily life and routines of attending an early childhood care and education setting.

\subsection{Description of participants}

Action research is inquiry that is done by or with insiders to an organisation or community, but never to or on them (Herr \& Anderson, 2005, p. 3).

I am a participant-teacher-researcher; I am at the centre of this research study. I am a middle aged, middle class Pakeha female. I am a wife; mother; student; teacher and at the time of conducting this research, the supervisor at the centre. I acknowledge that my values, beliefs and knowledge on my teaching and learning and children's learning have influenced the findings of this research. As this research impacts on the community of learners (Wenger, 1999) within the centre where I work I invited the members of the community, my manager, teachers, children (34, children aged 3-5 years) and their parents to be involved in this project as collaborative participants (see Appendices C-L). It was important to ensure throughout this study that I respected their rights and "remember that participants are participants not objects of study" (McNiff \& Whitehead, 2005, p. 10). 


\subsection{Data collection-action research tools}

Multiple methods of data collection were used this is consistent with action research (McNiff \& Whitehead, 2005; Whitehead \& McNiff, 2006), and case study approaches (Merriam, 1988; Yin 2003). Data collection involved one or more of the research tools described in the following sections.

\subsubsection{Reflective research journal}

Monitoring my action, critically reflecting on my actions and my learning is a significant aspect of the self-study research cycles i.e. "monitoring your learning involves self-reflection, as well as gathering data over time to show your learning has been advanced" (Whitehead, \& McNiff, 2006, p. 65). I began writing in my reflective research journal after the first meeting with my supervisor in order to record thoughts and ideas. As the research process progressed. I documented in the journal and notebook records of naturally arising discussions with children, parents and teachers that illustrated their feelings and views about portfolios and having the portfolios readily accessible in the centre. Discussions with teachers at staff meetings on the process and benefits for children's learning and improving teaching practice were documented in the journal and staff meeting minutes. I recorded the actions I had taken; my reflections on my practice and learning in relation to the research questions.

\subsubsection{Observations and photographs}

There is no particular moment when data gathering begins. It begins before there is commitment to do the study; back-grounding, acquaintance with other cases, first impressions. ... Many of these early impressions will later be refined or replaced, but the pool of data includes the earliest of observations (Stake, 1995 p. 49)

I had been thinking about my portfolio assessment practices for a considerable amount of time. My concern was that children's portfolios were not freely accessible. Many of my earlier thoughts, informal observations and professional development learning experiences held significance to this project and influenced my thinking. These are integrated in the data collection of this study. 
The observational data collection began at the beginning of April 2006 after the approval of my project by the Victoria University of Wellington Faculty of Education Human Ethics Committee and continued throughout the action research cycles until December 2006. Observations and photographs within the centre were collected in order to answer the research questions and to document:

- How children and teachers used the portfolios before they became accessible to children;

- The process of making the portfolios readily accessible, and how children used their portfolios when they became freely available;

- Children's contributions to the portfolios process.

The observations were an important part of the data collection process, to record and critically reflect on my practices of compiling and using portfolios with children. During the research cycles, as is current practice, my colleagues continued to collect learning story observations (Carr, 2001) and photographs of the children for their portfolios. The parents had all agreed that this material could be used for the additional purpose of this research. These observations enhanced the data collection and provided multiple perspectives of what was happening for children (Carr, 2001, Ministry of Education, 1996a, 2004).

\subsubsection{Open-ended interviews}

An open-ended interview schedule (Appendix M) was written prior to the first action research cycle and included in the ethics application. I interviewed children, parents and teachers before the portfolios were readily accessible. In all I interviewed thirteen children; the open-ended questions were designed to find out what children knew about their portfolios and how they used them.

Of the possible 32, parents, I was able to interview six over the same period of time that I interviewed the children. Finding the time was a challenge and proved to be more difficult than finding the time to interview the children. For many parents, finding the time for an interview was just impossible as I really wanted to find out their views. Therefore I asked the parents if they would take the question sheets and fill them in when they had time. This seemed to work really well and a further seven 
parents filled in and returned the completed questionnaires to me. In total, 13 parents provided their views through face to face interviews or in written form.

Before interviewing the teachers about how they used portfolios with children. I felt that it was important that I answered the questions regarding my own teaching practices of using portfolios with children. The open-ended questions (Appendix M) explored three concerns that I had about how I was using the portfolios with children;

- How often I sat down with the children in my portfolio group and looked at and discussed their portfolios with them;

- How often I sent their portfolios home or how often children asked me for their portfolios to take home;

- What were the barriers to how I wanted to use the portfolios with children?

I interviewed the teachers on the weeks of the $8^{\text {th }}$ and $15^{\text {th }}$ May 2006. I continued to gather data over the next twelve weeks observing and taking photographs of children using their portfolios alone, with friends, with teachers, with parents and whānau. I also spent time with children individually and with groups of children looking at their portfolios and listening to their views about their portfolios and their learning. During our conversations I wanted children to have the opportunity to add any information that was important to them so I asked children questions that were based on the open-ended interview questions (Appendix M). I had planned to interview the children using these questions at the end of the twelve week period. However it seemed more relevant to ask children the questions as part of our conversation in an authentic context rather than as a formal interview weeks later. Robbins (2002) describes this as a socio-cultural approach to interviewing children and recommends:

In thinking about any research which involves interviewing young children the researcher needs to consider how to design, structure and implement a process and interview schedule that is sensitive to the context of the particular children. Further, s/he should take into account the cultural tools and artifacts (sic) that are relevant to them (p.16) 
By using this technique I was trying to gain a deeper insight into children's thinking about their portfolios and learning. After the portfolios had been accessible for twelve weeks I interviewed the children, their parents and the teachers again to find out:

- What does "accessible" mean in my centre?

- How do children use portfolios when they are accessible?

- What does my data of children's use of portfolios suggest to me about what is happening for children?

- Did making children's portfolios accessible to them make a difference to teachers' practices and children's learning?

These questions are further developed and explored in chapter four.

\subsubsection{Document analysis}

Document analysis of regulatory and non-regulatory documents that frame up teacher practices on assessment became part of my ongoing reflection as I tried to meet my objective of turning the portfolios from being a product to a process for children's learning. The documents used in this way were: Te Whāriki: He Whāriki Mātauranga mō ngā Mokopuna o Aotearoa: Early childhood curriculum (Ministry of Education, 1996a); The revised desirable objectives and practices (Ministry of Education, 1996b); Quality in action: Te Mahi Whai Hua. Implementing the revised statement of desirable objectives and practices in New Zealand early childhood services. (Ministry of Education, 1998) and Kei Tua o te Pae: Assessment for learning: Early childhood exemplars (Ministry of Education, 2004).

\subsection{Data analysis}

Methods books like this one provide persuasions, not recipes. Each researcher needs through experience and reflection to find the forms of analysis that work for him or her (Stake, 1995, p.77).

In action research and case study research data collection and data analysis occur simultaneously (Huberman \& Miles, 1995) Analysing the data is concerned with "making sense" of it all (Punch, 1998, p. 200). The data collected throughout this 
study was analysed retrospectively in relation to the research questions in both cycles. So that I could arrive at a deeper understanding of what accessible meant in my centre. Additionally the issues, trends and themes that arose were examined. The data was also analysed in relation to the action research process of self-critical reflection "analyzing our own judgment, reactions and impressions of what is going on" (Cohen, Manion \& Morrison, 2000, p.229) and the implications for teaching practice. As a novice teacher/researcher I found this ongoing process challenging and complex. Therefore I used a variety of approaches (tools) as there is "no single right way to do qualitative data analysis-no single methodological framework" (Punch, 1998, p. 199).

Observations were one of the main tools I used for collecting the data. For the analysis of the observations I sometimes used a matrix (Appendix N) for sorting and coding the themes and issues that evolved from reading the data (Mc Naughton, Rolfe \& Siraj-Blatchford, 2001; Mutch, 2005). I also wrote comments at the side or at the end of the observations and highlighted these to further support my analysis of the data. The photographs that were taken at the same time as the observations were very useful they acted as prompts to further support my interpretations of the data. I also used a matrix in my reflective journal (Appendix N) for making sense of my actions, reflections, generating the evidence of the significance of my learning and how this influenced improving my practice.

The technique of memoing as suggested by a number of authors (Denscombe, 2001; Huberman \& Miles, 1995; Graue \& Walsh, 1998; Punch, 1998) was used for analysing the open-ended interview transcripts. The memos (Appendix N) that I wrote recorded my reflections, insights and my understanding of children, parents and teachers views about portfolio accessibility. This was a useful tool for identifying emerging themes and the connections to the research questions.

\subsection{Ethical considerations}

Approval for this research was obtained from the ethics committee in April 2006. As this research aims to improve my practice and improve children's learning I verbally 
invited the children their parents and the teachers to be participants in this study. This was accompanied by written information sheets and informed consent forms (Appendices C-L). Informed consent for this research was obtained by or on behalf of the participants. Written, drawn and verbal consent was obtained from the children.

Throughout the research process I continued to seek children's informed consent verbally; paying particular attention to any non-verbal signs children may give regarding their willingness to take part in the research process. This was to ensure sensitivity to their needs, dignity rights and safety (Cohen, Manion \& Morrison, 2000; Cullen, Hedges \& Bone, 2005). I also made it clear to the participants verbally that participation in this study would be voluntary. I provided a written information sheet and sought consent from my Manager to conduct this research study in the centre that I worked in (Appendix C-D).

\subsubsection{Ethical dilemmas}

Two ethical dilemmas arose during the first cycle of the action research in regard to gaining informed consent. I had decided ethically that it was important to gain informed consent first from parents for their children to be involved in the research study, before I sought informed consent from the children. When I began interviewing children about their views on their portfolios not all of the parents had signed the consent form. Isaac's Mum had not signed the consent form. However, Isaac wanted to be interviewed. I explained to Isaac the reasons why I could not interview him. At the time I believed I had made the right ethical decision. I was concerned that a parent may not give permission for their child to be involved after I had gained informed consent and interviewed their child. A study by Danby \& Farrell (2004) revealed that they encountered the same ethical issue in their (2002) study

One child indicated that, while they wished to participate, their parents did not give their permission. This raised theoretical questions regarding adults contesting children's desire to participate as emblematic of adult governance of children's lives (p.39). 
The second dilemma was in relation to choosing a pseudonym, on the parents consent form I asked parents to choose a name for them and their child. Only a small number of parents chose a pseudonym. When gaining informed consent from the children I said to them "I won't use your name so people won't know they are your words". Three of the children asked me what the names were that their parents had chosen. Two of the children decided that they wanted to choose their own pseudonym. I explained that I would need to ask their parents if they were in agreement first, the parents agreed to the children's choice of names.

After further reflection on my values beliefs and view of children that they were competent and confident learners (Ministry of Education, 1996a) my actions did not reflect my beliefs. My actions were controlling, the first dilemma demonstrates there was no sharing of power, however there was some sharing of power in the second dilemma. In hindsight this was an unexpected outcome. In the future if I were to engage in research involving children, I would respect their rights to give their informed consent without first asking their parents for permission. This argument is further supported by children's participation rights in The United Nations Convention on the rights of the child (UNCROC) Article 12 states "you have the right to say what you think should happen when adults are making decisions that affect you, and to have your opinions taken into account"(Office of the Commissioner for Children, 2005). Some of the children after giving their informed consent chose not to be interviewed and I respected their rights not to be involved.

\subsection{Robustness and trustworthiness}

As action research is often seen as a "messy and weak form of research" (Cardno, 2003, p. vii) it was important that the research design, data gathering and analysis were clearly documented and the findings demonstrated trustworthiness and were robust. Toma (2006) suggests that research "approaches based on trustworthiness and authenticity do not dismiss validity instead recasting it in more relativist terms and highlighting rigor in the application of the methods" (p. 410).

In qualitative studies "the use of multiple data collection methods has been used to validate research findings" (Anderson, 1998 p. 131). This is further supported by 
Cohen et al. (2000) who propose that "triangulation can be a useful technique where a researcher is engaged in case study, a particular example of complex phenomena." The data collection in this research included the use of multiple methods including: a reflective research journal, observations, photographs, discussion and document analysis. I believe the use of triangulation (Anderson, 1998) in this study added to the robustness and trustworthiness of this research.

Reliability in qualitative research seems to be a controversial issue as Cohen et al., (2000) argue

In qualitative research reliability can be regarded as a fit between what researcher's record as data and what actually occurs in the natural setting that is being researched (Cohen, et al., 2000, p.119).

Of particular relevance to this research study is the notion of member checking (respondent validation) (Cohen et al., 2000) in relation to the open-ended interviews I conducted. I read back to children what they had said to me and what I had written after their interview. Copies of the interviews were put in the children's portfolios.

Instead of being interviewed, most of the parents answered the open-ended questions as a questionnaire. I checked with them that they were satisfied with what they had written. For the parents I did interview, I repeated what they had said to me and showed them what I had written. After typing the teacher's interviews I sent them back to them via email in order to offer them the opportunity to add additional information. Most of the teachers did add additional information.

To ensure trustworthiness in this research study the data collection presents a truthful and honest account of the events I recorded of what was happening at the centre. All of the data is consistent with these findings (Toma, 2006).

\subsection{Limitations of the study}

This small scale action research study was conducted by a novice teacher researcher. Generalisation of this study is a limitation and is considered to be a weakness of the action research approach. This study was conducted in only one early childhood care 
and education centre. As it presents an insider perspective, my world view on how I improved my teaching practices through making portfolios accessible to children where I worked as the supervisor/teacher the findings may not be generalisable to other early childhood care and education centres. However, as Bell (1999) argues "the study may be relatable in a way that will enable members of similar groups to recognise problems and possibly see ways of solving similar problems in their own group"(p.13).

Gender issues were not a consideration of this study. A limitation of this study could be gender bias. The teacher researcher was female; the other teachers were all female; usually mothers or women caregivers brought children to the centre. Participants in the research were predominately female with only two father's available interviewed (Goodwin \& Goodwin, 1996; Graue \& Walsh, 1998).

Making the time to gather the data was a constraint and the analysis process was demanding. Mutch (2005) suggests that "action research is a good place for beginning researchers to start, and it's a manageable way for busy practitioners to continue researching" (p. 203). This implies that researching ones' own practice can become part of the workload. This certainly was not the findings of this study as the self-study research process was time consuming, complex and challenging. I found that my workload had an impact on the time available for conducting this study and writing up the research (Herr, \& Anderson, 2005).

\subsection{Summary}

This chapter discusses the reasons why a qualitative research design was chosen for this study as the main aim of this study investigated the process of making the children's portfolios in the centre where I worked, accessible through discussion, reflection and observations in a natural setting. This chapter has described the action research self-study and case study approaches used in this study and why these research methods were used to explore; how I could improve my practices and my role in improving the learning outcomes for children by making portfolios accessible and involving them in the portfolio process. As the teacher researcher I am at the 
centre of this study I provide an insider perspective that investigates my world view and understanding of the action research process. The following chapters 4,5 and 6 describe the self-study action and reflection cycles and the findings of this study. 


\section{Chapter Four}

\section{Making Portfolios Accessible}

\subsection{Introduction}

This chapter describes the first self-study research cycle and addresses the following research questions:

1. How do children use portfolios?

2. What will I do to make children's portfolios accessible to them?

3. Will making children's portfolios accessible to them make a difference to teacher practices and children's learning?

4. What are the benefits of conducting action research as a means to improve my pedagogical practices?

I also explored children's, parents and teachers thinking about portfolios and children's learning as I tried to answer the research questions using the continuous process of action and reflection (McNiff, 2002; McNiff \& Whitehead, 2005; Whitehead, \& McNiff, 2006). The chapter begins with an explanation of what "accessible" meant in the centre before the research began and why I was concerned about my portfolio assessment practices. The second section explores the process of making the portfolios accessible and therefore implementing the changes as a way of improving the use of portfolios. I also describe how children used their portfolios when they became freely available. The third section investigates the outcomes of my actions and reflections. The findings illustrate how making children's portfolios accessible changed the practices of the teacher's and the learning of the children. The chapter concludes with a discussion around the word accessible and how this had shifted during phase one of the action research resulting in the questions for the second action cycle.

\subsection{What did accessible mean in my centre?}

I reflect on all the lost opportunities for children's reflection and self-assessment of their learning by not 
having the portfolios accessible (Reflective research journal, 13/08/05).

At the start of the research children's individual portfolios were kept in a filing cabinet in the centre office. Children and their parents could view the portfolios on request however; they did not ask for or access the portfolios on a daily or even a weekly basis.

I had identified this practice as a problem nearly four years ago, in 2003. Since this time there had been ongoing discussion about how to make children's portfolios accessible, however, the teaching team at that time voiced the following concerns:

- Privacy issues; would other children and parents look at portfolios other than their own or their child's?

- Would children's learning and development be compared, or would there be comparisons made of how much documentation was in each child's portfolio?

- Would the portfolios become damaged if children did not put them away, or took them into other areas of the centre?

- The need to discuss with children and their parents if they wanted to have their portfolio readily accessible.

- Keeping the portfolios up to date during a working week when the proportion of non-contact to contact time is 3:34 hours, and teachers feeling a sense of vulnerability about their work being "exposed".

- Establishing realistic expectations about the purpose, contents and ownership of the portfolios among teachers as well as parents.

Our ongoing discussions demonstrated that changing teaching practices is not clearcut and is often complex. As a teaching team we had not established a "shared sense of purpose (Anning \& Edwards, 2000, p. 149) for having the portfolios accessible. They suggest:

A shared sense of purpose takes time to achieve and can't be imposed. Quite often a sense of coherent 
purpose only emerges in the process of discussion and action as colleagues clarify what they mean (p. 149).

In March 2004 the Education Review Office (ERO) conducted a review of our centre. In their report not having children's portfolios accessible was recommended as an area for improvement. This report and the decision by the teaching team to make the portfolios accessible provided me with the rationale to address my concern. The area of practice I investigated was my role in making children's portfolios accessible. In order to implement a solution (Appendix A) and change my teaching practices five important issues were first explored:

\subsubsection{Self-study reflective cycle}

1. Children's views about their portfolio

2. Parents views about their child's portfolio

3. The children's current use of portfolios in the centre and at home?

4. My current teaching practices regarding using portfolios with children

5. My colleagues' current teaching practices on how they were using portfolios with children

\subsubsection{Children's views about their portfolios}

When I was reflecting on my practice of not having the portfolios accessible to children I thought that a number of children may not even know what their portfolio was. If this was the case they certainly would not feel ownership of their portfolio. Tina (parent) also felt that her child did not have a sense of ownership about his portfolio as he never asked to look at it; "I feel Jack does not have an understanding that it is his; rather that it is an adult's thing" (Interview, 5/05/06)

The literature I reviewed (Chapter 2) on portfolios clearly demonstrates that ownership is a significant issue that needs to be considered as Herbert (2001) argues

All teachers need to confront the ownership of the portfolio as it arises with each student. "Is this my portfolio of teaching supported by you?" or "Is this your portfolio of learning supported by me?" is the implicit teacher to student question (pp. 43-44). 
The open-ended interview questions (Appendix M) were based on finding out what children knew about their portfolio and how they used them. I interviewed thirteen children, and only one child's response indicated that they did not know what their portfolio was:

I was rather relieved. I asked Maya (3.9years) "Can you tell me about your portfolio"?

Maya replied "I haven't got one".

Lynne: "the book I write in about you the one with your birthday in it".

Maya: "the purple thingy"? (The portfolio is covered in purple paper).

Lynne: "yes that is your portfolio book" (Interview, 4/05/06).

When Maya seemed to understand what I was asking her about she was able to tell me what was in her portfolio. On reflection was it that Maya did not understand the word portfolio or was it because it is physically inaccessible? Interviewing the children provided me with some valuable insights. I learnt that all the children knew what was in their portfolios; photographs and art work, although only Joshua mentioned there being a story in his portfolio. What seemed really significant to the children were the photographs not only of them but of their friends. Charlotte talked about contributing to her portfolio and said: "I like to take photos of things. My Mum puts photos in there" (Interview, 4/5/06)

Charlotte's portfolio book was at home and I asked if she could bring it back so I could add more to it. When the portfolio was returned there were no photographs added. I did follow this up and tell Charlotte and her Mum, Niki, that they could put photographs in the portfolio.

The children's responses to the interview (Appendix M) question "can you tell me if you like to take your portfolio home? in the examples below illustrate children's thinking about their portfolios; this includes knowledge about access and ownership. They all seemed to know that they could take their portfolios home, and they did this to look at their portfolio either alone or to show to others:

Lynne: "can you tell me if you like to take your portfolio home?"

Maya (3.9 years): "I like to keep it and put other photos in it".

Isaac (4.5 years): "Yes because I like it". 
Kanako (4.3years): "Yes"

Joshua (3.8 years): "I like to take it home to show everybody"

Dale: "Yes because it's my portfolio

Christina (4.10 years): "Yes so I can take it home to Vietnam, I show my Grandma and Daddy what I do”. (Interview 4/05/06)

Jane (teacher) sends emails of learning stories to Christina's Mum and she then forwards them to Christina's Dad in Vietnam. These are then added to Christina's portfolio.

After completing the interviews with the children I reflected on the importance of really listening to children views to gain an understanding of their thoughts and ideas. Clark and Moss (2005) "emphasise that listening is an active process, involving not just hearing but interpreting, constructing meaning and responding" ( $p$. 7). I felt that it was also important that children knew that they could contribute to their portfolios and their contributions would be valued. I would need to make changes to my practice when compiling the portfolios for this to happen (Hebert, 2001; Te One, 2000). This reflection links to the importance of the teachers role in supporting children's learning and the principles of empowerment, relationships, the strand and goals of contribution as expressed in Te Whāriki (Ministry of Education, 1996a) "the programme should recognise, acknowledge and build on each child's strengths and allow each to make a contribution" (p. 64).

\subsubsection{Parent's views about their child's portfolio}

The parent's responses to the interview questions (Appendix M) provided valuable evidence of their views on their child's portfolio. There were several similarities, their comments included:

"Portfolios are fantastic. Showed it to friends who are amazed by it. Haven't seen anything like it".

"Portfolios are fantastic a good link between Preschool and home" (Interviews 5/5/06).

The parent's responses to making the portfolios accessible included:

"It will be good to see them out there and being looked at by the kids; really good idea to make them available, children can share them with each other 
and with family"; "I think it is good they are going to be accessible; children would be able to constantly go over experiences and ask to repeat experiences".

"Grandparents are amazed by them. They are such a good record".

"I love the portfolio books - they help alleviate the feeling of missing out by not being a fulltime Mum” (Open-ended questionnaire, 15/5/06).

The analysis of the parents' views of the portfolios confirmed the value of the portfolios for children's learning as well as providing them with an ongoing record of their child's learning and achievements (Cohen, 1999; Helm, Beneke \& Steinheimer, 1998). The parent's views supported the portfolios being fully accessible. They understood the benefits children would gain by looking at their portfolios more often and revisiting their learning experiences (Carr, 2001; Potter, 1999; Smith, 2000; Te One, 2000, 2002).

\subsubsection{The children's use of portfolios at the centre and home}

Children sometimes asked to look at their portfolios at the centre, or teachers spent time with children looking at them and discussing the photographs and what was happening. Occasionally children would look at their portfolios with their friends. Children used them in similar ways as they did at home. This is illustrated in the summary of parent' comments on how they and their child used the portfolios at home:

- Only a few parents looked at their children's portfolios alone, they all looked at it at together with their child; some shared it with their child and their sibling's whanau and friends.

- The children looked at the pictures and told stories about what was happening; this included elaborating on what was written adding their own voice to the stories.

- Friends were very important, showing their parents who their friends were and discussing their play with friends or looking for them in the photographs was a common response (Interviews 16-19/05/06 \& open-ended questionnaires 22-26/05/06). 
This summary shows that portfolios can be used as an effective visual, communication and relationship tool for supporting and making the "connecting links between the early childhood setting and other setting that relate to the child such as home" (Ministry of Education, 1996a, p. 56).

\subsubsection{How I was using portfolios with children: the problem}

In order to improve my teaching practices it was important to critique my current teaching practices and explore my concerns about how I was using portfolios with children. The open-ended teachers' interview schedule (Appendix M) focused on three of these concerns:

- How often I had sat down with the children in my portfolio group and discussed their portfolios with them. There were four portfolio groups, one group per teacher; each teacher was responsible for compiling eight children's portfolios;

- How often I sent their portfolios home or how often children asked me for their portfolios to take home.

- What were the barriers to how I would like to use the portfolios with children?

In the twelve months prior to the research there were a few occasions when I sat down with children and looked at their portfolio with them. I did however spend at least three hours per week of non contact time compiling their portfolios. Nevertheless, if it was not possible to have non-contact for any particular reason, usually when teachers were sick or on holiday, I would often take the portfolios home to work on. None of the children in my group over the past twelve months had asked me to look at their portfolios in the centre.

Keeping the portfolios up to date when the proportion of non-contact to contact time is 3:34 hours, is often difficult. Te One (2002) identified compiling portfolios for teachers was at times frustrating and unmanageable.

Although the process of compiling the portfolios was time-consuming, all the teachers regarded them as extremely valuable and worth while because of what 
they learnt about children in relation to the programme (p.12).

I did value children's portfolios; I wanted to have the time to sit down with children and share their portfolios with them. I wanted to listen to children's voices and hear what they had to say about their experiences, photographs and their art work and to document these (Alcock, 2000; Te One, 2002).

There were a number of barriers preventing how I wanted to use portfolios with children including:

- The portfolios were inaccessible to children: They were kept in a filing cabinet in the office.

- Making the time to spend with children during the day or during my noncontact time was difficult because of staffing, ratios, the roster and routine times

- The added responsibility of being a supervisor/teacher the professional leader in the centre.

After critically reflecting on my practices of compiling and using portfolios with children I identified a considerable mismatch between my educational values, beliefs and practice, or as Whitehead and McNiff (2006) argue "we experience ourselves as living contradictions when our values our denied in our practice" (p.25).

\subsubsection{How my colleagues used portfolios with children}

I interviewed the teachers using the same open-ended questions (Appendix M) to find out how our responses compared. I found there were differences in how often children asked to take their portfolios home and how we used portfolios with the children. However there were a number of similarities to how frequently the children's parent's asked to take their child's portfolio home; how we would like to use portfolios with children and the barriers that prevented teachers using the portfolios in a way they deemed appropriate.

Three of my colleagues, Penny, Amy and Jane, had sent home the portfolios of the eight children they were each responsible for compiling on a more frequent basis than I had. Between two and four children in each of the teachers groups had asked 
them if they could take their portfolio home compared to none of the children from my group asking me.

When I interviewed Jane she said that: "some children from other groups have asked $m e ”$.

Penny said that "when other children heard Luke Skywalker asking to take his portfolio home they wanted to take their portfolios home”. (Interview, 14/04/06).

Perhaps there could have been children from my group who had asked to take their portfolios home, as Jane and Penny could not specifically remember which children had asked.

It was evident from the interview responses of Penny, Jane and Amy that there was a significant difference in how we used portfolios with children. Penny, Jane and Amy had over the past few months sat down with children and looked at their portfolio with them between one and five times, whilst I had not.

After analysing the responses of the teachers and comparing those with mine there were a number of similarities between how we would like to use portfolios with children. Most teachers agreed that having the portfolios out in the centre and sharing the portfolios with the children was important. In addition, children being involved in the process of compiling their portfolios moving from teacher ownership to teacher, child and parent ownership of the portfolios was also a priority. Working collaboratively with children encouraging them to choose the photographs and document their stories was regarded as an important way of involving children in the portfolio process.

I learnt from the interviews we had all identified some of the same barriers for how we would like to use the portfolios with children these were:

- Time

- Staffing and ratios

- Inaccessibility of the portfolios for children 
- Lack of equipment; (we only have one digital camera; two computers that are in the office and one printer).

The data from the interviews and my critical reflection showed that the differences in our practices, and the barriers preventing how we used portfolios could be attributed to the "structural pressures and realities" (Nuttall, 2005 p.14), such as staffing, ratios and the programme. This is supported by Nuttall's (2005) argument that "the-day-today demands of centre life meant that the teachers had very few opportunities to explore their thinking and practice together in a conscious, reflective way" (p. 19).

\subsection{Making children's portfolios accessible to them: The solution}

I had spent a considerable amount of time thinking about the physical accessibility of portfolios. The question of where should they be located and stored to ensure they were available at all times to children was a reoccurring one? The importance of the environment and the location of the portfolios can play a significant role in their use. My thoughts were further supported when I read an article on the Roskill South kindergarten Centre of Innovation. Karen Ramsey (2000) wrote in her log book

I was watching two children reading their files to each other. They were having to sit in the doorway as the files were stored in a bookcase just inside the door. Did this show the children we value their stories? As a team we thought it didn't and decided to create a learning stories corner! (Ramsey, Breen, Strum, Lee, \& Carr, 2005, p. 26).

I asked the children if they thought it was a good idea for the portfolio boxes to be put beside the book case next to the table and near to the book corner. The children were in agreement with the location. On reflection I had used a closed question; what choice did I give to children about the location of the portfolios? I did not consult with the children only the teachers and their parents. If the children had said that they did not agree I would have listened to their perspectives and perhaps changed the location, Smith (1998) argues:

Giving more emphasis to children's perspectives will, I believe, produce better and more ecologically and socioculturally based research, which will provide a 
richer and more meaningful understanding of effective contexts for children's development (p. 71).

\subsubsection{Portfolio ownership}

Portfolio ownership was another significant issue that I had spent a considerable amount of time reflecting on and discussing with my colleagues and parents. Clearly the portfolios were teacher organised as we were in control of the portfolios. Discussing with children the concept of ownership and making the portfolios accessible I believed were the first steps in working towards shared portfolio ownership between teachers, children and their parents. (Hebert, 2001).

We emphasise the importance of exploring children's views and experiences of everyday life in the institutions they attend; as members of communities rather than consumers or users of a product (Clark, \& Moss, 2005, p. 8).

Before putting the portfolios out in the centre I spent a week (22/05/06-26/05/06) initiating discussions with children about my research; portfolio accessibility; why this was happening; the value of, or what is special about their portfolios and portfolio ownership. Really listening to and documenting the children's views over the week provided me with further insights in to their thinking and understandings about their portfolios; they were active participants in these discussions (Clark, \& Moss, 2005; Smith, Taylor, \& Gollop, 2000). When I asked the children:

"Can you tell me what is special about your portfolio"? The children told me that their books were special because it had a photograph of them on the front and photographs inside. Some children said they could not rip their books and others told me they would look after them (research journal entries, $22-25 / 05 / 06)$.

My discussion with children on portfolio ownership focused on the book being theirs. I wanted children to develop an understanding that they owned the book. The teachers contributed to their booking by adding artefacts such as learning stories and art work. Their parents would also look at their book. However, if other children or parents wanted to look at their book they would need to ask them. I wanted to ensure that each child's book would be in the container when they wanted to look at it, or contribute to the contents of their portfolio. 
At the end of the week (26/05/06) when I asked them:

"Can you tell me who you would like to share your portfolio with?" The replies included; Mums; Dads; and friends. I asked the children "if you want to look at your friend's book will you take it and look at it?" "No" was the chorus. I asked when "can your friends look at your portfolio?” They replied "your friends have to ask you if they can look at the book". I also asked: "can you show them to your friends Mums, Dads or visitors?" "Yes if you want to you can" came the reply (research journal entry 26/05/06).

The children's responses provided me with insights into their understanding of portfolio ownership. I felt by discussing these issues each day with the children and allowing them time to think about what I was saying, the children were beginning to really understand what portfolio ownership meant for them and the reasons for the portfolios becoming accessible. We were developing shared meanings and understandings; we were co-constructors of knowledge (Bodrova \& Leong, 2007; Clark \& Moss, 2005; Edwards, Gandini \& Forman, 1998; Rogoff, 1990; Rogoff \& Lave, 1984) Sociocultural theories suggest that "knowledge is constructed by children through interactions with others (Smith, 1998, p. 72).

It seemed children's thinking and ideas about their portfolios and my research were becoming more complex. There was a really interesting episode that happened on the Wednesday of that week that demonstrated children's complex thinking and learning as the following journal entry demonstrates. Each day at afternoon tea one of the teachers asks the children about their day at the centre their comments are written down by the teacher on a whiteboard:

Today Jane (teacher) asked "would anyone like to tell me what they enjoyed doing today? Flora replied "I was using the new pens and some paper to do my research". (Reflective journal entry 25/5/06)

A number of other children also called out that they were doing research too. Flora had given her informed consent to be a voluntary participant in my research and I had interviewed her (interview 23/05/06) Flora was also an active participant in the discussions. I believe Flora was making links between her personal experience of 
being interviewed and revisiting this experience in her play in the role of the researcher (Paley, 2004; Rogoff, 1990).

\subsubsection{Portfolio accessibility}

Monday $29^{\text {th }}$ May 2006 was such an exciting and long awaited day for me. Finally, after three years, I was going to put the portfolios out in the centre. My expectation of what would happen when the portfolios were put out was that children would really want to look at them, alone or with friends, teachers, parents and whānau (Ministry of Education, 1996a, 2004; Ramsey et al, 2005).

The organization of classroom space can enhance the sense of ownership and control of the environment-an important element in a child's learning (Herbert, 2001, P. 74).

I decided to involve the children in putting the portfolios out. I waited until a large number of children had arrived and then began the process out in the centre. The children helped me carry the portfolios and the suspension files to where I had put the container that they would go in. I put a name tag on the top of the suspension files. The children were interested in trying to guess whose name I was writing and when their portfolio would be put in the file. As more children arrived Emilie seemed to take great delight in telling each child that their portfolio was being put out.

\subsubsection{Children's use of portfolios: what is happening for children?}

Much like their teachers, the children need to engage in the physicality and concreteness of the portfolio before they can begin to appreciate the abstract qualities of its purpose (Herbert, 2001, p. 56).

When the portfolios became accessible to the children, some of them, each day and throughout the day, spent a considerable amount of time looking at their portfolios, or having the stories read to them, sometimes alone, or with a teacher or their parent's. Most of the children looked at their portfolios either sitting at the table or on the cushions in the book corner. This has stayed consistent over the twelve weeks of the first self-study research cycle and is still currently happening. This supports Carr's argument that:

Assessments need to be accessible to the children. This usually means that they will have to be read back, 
and/or they include photographs. In many centres the children's portfolios are readily available, and children revisit their stories, often with parents, peers and/or teachers (Carr, 2004 p. 38).

I have also found that since the portfolios have become accessible the book corner is hardly ever untidy. Books are returned to the book case just like the portfolios are returned to the boxes. I spoke with the teacher responsible for mending books and she told me that hardly any books needed to be mended. This was an unexpected outcome and I believe the discussions we had about the portfolios being special and the children's commitment to looking after their portfolios was one of the reasons why this has happened. A significant benefit of making the portfolios accessible was it made their learning more visible to them. Children have developed an understanding that their portfolios are of value to them, their friends, parents, whānau and teachers. (Hebert, 2001; Rogoff, 1990; Whalley 2001).

Children's use of their portfolios confirmed for me the importance of making children's portfolios accessible to them. It was also consistent with the arguments in the literature about the potential of portfolios for promoting children's reflection and self-assessment when children share their portfolios with teachers and peers on a frequent basis (Cohen, 1999; Helm et al., 1998; Potter, 1999; Smith, 2000; Te One, 2000, 2002).

Children reflecting on their experiences and retelling their learning stories to friends, teachers, parents and whānau was a recurring theme in the observations and interview responses. When I was interviewing Emilie and asked her if she could tell me about her portfolio, Emilie went and got it. Emilie found a picture in her portfolio that was taken at the centre she had been at the year before. Emilie said "I like the birthday I was at toddlers". Emilie counts the candles, "1, 2, 3, I was three years old”. (Interview, 17/08/06).

When I was interviewing Isaac he pointed to one of the photographs and said "this was hours ago" as he pointed to the date on the story (Interview, 17/08/06). Emilie and Isaac were developing their own theories of time. Emilie knew her photographs were from when she was three years old and she is now four years old. Isaac knew 
that the date was significant as it told him when the photograph was taken. Emilie and Isaac are developing their own understandings of their learning (Smith, 1998, Ministry of Education 1996)

\subsection{Portfolios making a difference to teaching and learning}

One of the most significant areas of interest in this research project involved the following question - will making children's portfolios accessible to them make a difference to teacher practices and children's learning? The answer to this question is an emphatic "yes" there has been a considerable impact on how my actions as a teacher researcher impacted on what happened in the centre in relation to the accessibility of portfolios. I made a number of changes to my practices and the other teachers also made changes to their practices after the portfolios became accessible.

Critically reflecting on my practice was ongoing, and I made changes to my practice as I gathered, analysed and evaluated the data throughout this self-study cycle (Mc Niff, 2002; Mc Niff, \& Whitehead 2005). For example:

- Making time to look at children's portfolios with them. Children regularly invited me to look at their portfolios with them.

- Speaking with children about them, choosing to put things like art work into their portfolios. In this way I was trying to encourage them to contribute to their portfolio-a change for children to choose what was significant for them rather than me choosing.

- Encouraging parents to contribute to the portfolios so I asked questions at the end of their child's learning stories. For example, when a child was showing a particular interest in the process of cooking. I asked the parents if the child was interested in cooking at home and the things they liked to cook. One of the children did not speak any English: her parents did, so I asked them what she said about the centre; what she would like to do at the centre and what her interests were at home.

- I wrote the story to the child instead of writing about the child.

- I included a group photograph of the teachers in the portfolio and a small story about me. 
- As a team we made changes to the portfolio introduction (Appendix O). As a result of making the portfolios accessible the portfolio as we had developed showed a shared sense of purpose contents and ownership of the portfolios:

- The other teachers made a number of similar changes to their practices as previously discussed, after the portfolios became accessible. They discussed with me the benefits they had observed:

- We have seen an increase in parent communication through the portfolio books. We have been using the books as a way to ask them what has been going on at home and to enable them to contribute things to their children's books. For example the parents were replying to the questions that were added to the learning stories and when the parents made comments about children's interests and experiences at home we added this documentation to the stories as the parents' voice.

- The children look at their books more often now they can access their books on a daily or at least a weekly basis. Children ask to put work in their books such as art, or photographs they point out things they remember; things they find important. They revisit activities that they have done before, furthering their learning.

A further benefit of portfolio accessibility was that the parent's seemed to become more involved in their children's learning and experiences at the centre and their interview (Appendix $\mathrm{M}$ ) responses demonstrated this:

"He knows he is involved in his own learning".

"She takes tremendous pride in sharing her achievements and accomplishments. She has a growing sense of her own progress from the first portfolio entries to the most recent entries".

"I think Flora really enjoys having access to her portfolio; she certainly talks about it a lot".

"It allows her to share with me her days at crèche that otherwise would not be talked about. She enjoys her portfolio being all about her, her friends and teachers" (Interviews, 23-24/8/06). 


\subsection{What does "accessible" mean in my centre}

At the beginning of this research journey I found there was very limited discussion in the literature on what "accessible" means. The literature review (chapter 2) describes accessible in terms of physical accessibility and intellectual accessibility (Barrett, 2005; Cohen, 1999; Helm et al., 1998; Potter, 1999; Smith, 2000; Te One, 2000, 2002). The data and the findings provided the evidence that physical accessibility is more than having the portfolios available for children and their parents to look at. Children needed to be able to physically access their portfolio when they wanted to. For some children, this was not possible as all of the children could not recognise, or read their name on the divider in the box were the portfolios are kept as the following discussion illustrates.

When I interviewed Nadia (teacher) she said she had observed a number of children having difficulties in finding their portfolios; Nadia explained that taking them out of the files and putting them back was challenging. Younger children could not read or recognise their names on the tags on the top of the files. The files were very rigid and the space between each file was minimal. Consequently, some children depended on or needed help from a teacher or a peer (Interview 24/8/06).

This indicated that as the teacher, I needed to make changes so that all children could access their portfolios. More flexible dividers were made. On top of these a photograph of the child was attached. In making this change the children were interested in being involved in the process: They helped me laminate the photograph name tags and they watched me cut the dividers and put the portfolios back in the boxes. I learnt that small changes can make a big impact. In this case it meant that all the children were able to fully access their portfolios. A teacher who came in to relieve and a professional development advisor commented on this change and said how visually appealing they looked.

In relation to intellectual accessibility it appears that the portfolios are comprehensible to children and their parents and children are using their learning stories to reflect on their learning. However, they are not fully intellectually accessible to children. The data clearly identifies that this was not happening for children. They were only occasionally contributing to their portfolios these 
contributions were limited to requests of putting their art into their portfolios and the occasional requests to have photographs added. For example, when Luke Skywalker $(29 / 05 / 06)$ read his portfolio, this prompted him to revisit his experience of taking apart machines. He then asked Penny (teacher) to take his photograph. After Penny had been on non-contact he was very interested in looking at the photograph and listening to the story in his portfolio.

The stories in the portfolios of the children I compiled showed that there were no documented ongoing discussions with children about their learning. I wrote down what children were saying when they were involved in the learning experiences I was documenting. However, there was no continuity the child's further reflections on their learning and experiences were not documented - the "child's voice" was missing (Dahlberg \& Moss, 2005; Clark, \& Moss, 2005; Te One, 2000). I had not involved the children in the portfolios process. On further reflection, the reason why children were only occasionally contributing to their portfolios became clearer - my practices did not support or encourage children's participation or their contribution. Although Penny and Jane had begun to seek children's contributions it was not part of the centre culture or as Te One's 2000 study illustrates we had not developed shared "portfolio pedagogy" (p. 9).

When I interviewed the children I asked "do you choose photographs or art to put in your portfolios"? The children either answered "yes" or "no"; Charlotte was the only one who gave a reason as to why she said - "I want to put them in my portfolio because then I will have more pictures". I felt that children were developing a sense of ownership of their portfolios; however contributing to their portfolios was not part of this understanding as I had not discussed with them how we could work together. I was not sharing "the ownership of the portfolio with the child by allowing the child to select the contents and the reasons for the selection" (Hebert, 2001, p. 46).

A couple of weeks after I had interviewed them Maya and Charlotte kept bringing me pieces of their art to add to their portfolios. I wondered if they were making links between what I had asked during my interview and their understanding of being able to contribute to their portfolios. It also shows the progress of their thinking and 
understanding about their contributing to the portfolio process (Cohen, 1999; Helm et al., 1998; Potter, 1999; Smith, 2000; Te One, 2000, 2002).

The aim of this research was to explore how I could improve my practice and support children's learning. By making the children's portfolios physically accessible, I had made some improvements to my practice and that seemed to be having a positive effect on children's learning. However, I was still not fully involving children throughout the portfolios process; the portfolios were not fully intellectually accessible to children. I also felt that although children were developing a sense of ownership of their portfolios, this still needed to be further developed and they needed to have more control of how their portfolios were organised. I needed to make further changes to my practices (Hebert, 2001). These issues provided me with a new problem and the questions for the second self-study action research cycle (Mc Niff, 2002).

\subsection{Self-study cycle two questions}

1. What will I do to involve children in the portfolios process?

2. Will involving children in the portfolio process make a difference to teacher practices and children's learning

3. What are the benefits of conducting action research as a means to improve my pedagogical practices?

The following observation further strengthened my reasons for the research questions I wanted to explore. I had written the cycle two questions in my research journal on 4/9/06. On the 21/9/06 I was outside when Penny (teacher) came rushing outside: she was so excited about the observation she had just recorded. Charlotte and Maya were interviewing each other using some of the questions I had asked when interviewing the children for this research and the questions we had asked the children as part of our centre self-review. They used paper and pens to record their answers:

Charlotte: "What do you like about your portfolio?"

Maya: "Putting things in it".

Charlotte: "Who do you like looking at it with?" 
Maya: "You”

Charlotte: "Who puts pictures in your portfolio?"

Maya: "Lynne"

Charlotte: "Do you bring it home?"

Maya: "No".

Charlotte: "Do you look at the pictures?"

Maya: "I like looking at it by myself when it is quiet. I make pictures for it to put in".

Charlotte;" is that it?"

Maya: "I like looking at the pictures when it is loud sometimes

what are you doing Penny?" (I did not reply charlotte gets more paper).

Maya: "I like looking at it when Lynne is on the phone".

Charlotte: "What else do you like looking at, pictures?"

Maya: nods.

Maya gets paper and takes on the role of the interviewer.

Maya: "What do you like doing in your portfolio?”

Charlotte: "I like looking at with you and sometimes on my own".

Charlotte: "What are you writing about?"

Penny: (teacher) I tell her I am writing about what they are writing about.

Maya: "What do you like doing at Preschool?"

Charlotte: "Pushing swings and everything. What do you like?"

Maya: "Everything".

Teacher Elizabeth: comes over and asks them "what are you writing”?

Charlotte: "Everything".

Charlotte: "What do you like looking at best?"

Maya:" Umm".

Charlotte: "The teachers?"

Maya; "Yes the teachers". (Observation, 21/09/06).

This observation certainly demonstrated children's complex thinking as they engage in a "cognitive activity" using cultural tools, exploring social relationships and previous experiences. According to Rogoff (1984):

Central to the everyday contexts in which cognitive activity occurs is interaction with other people and use 
of socially provided tools and schemas for solving problems. Cognitive activity is socially defined, interpreted, and supported (p. 4).

\subsection{Summary}

This chapter has discussed the data in relation to the literature on the need for making portfolios "accessible" in my centre and what "accessible means". "When we are involved in something, we often don't make sense of it while we are actually doing it" (McNiff \& Whitehead, 2005, p. 190). This self-study action research cycle has allowed me to stand back, critique and explore how I improved my practice and children's learning by making children's portfolios accessible to them. The data describes my action research 'in action' and my continuing self-reflection. The data and the analysis of the data provided me with valuable insights about children's, parents, and teachers thinking about portfolios and children's learning. In the following chapter I explore how I involved children in the portfolio process and how I improved my portfolio assessment practices. 


\section{Chapter Five}

\section{Involving Children In The Portfolio Process}

\subsection{Introduction}

This chapter has two parts - the first part focuses on the second action research cycle looking at how I encouraged and involved children in the portfolio process. The second part of the chapter explores how this cycle has influenced my teaching practices and my learning. The first section of the chapter describes how the research questions emerged from the first cycle and how children were contributing to the process before during and after making the portfolios accessible. The second section examines the challenges of improving my teaching practices. The final section presents and discusses the evidence surrounding the potential significance of this study and how it has influenced my teaching practices and learning, my colleagues teaching practices and learning and children's learning.

\subsubsection{Self-study reflective cycle two}

My concern about the level of teacher control over the selection of the content and ownership of the children's portfolios became an important issue for me towards the end of the self-study action cycle one. The questions this concern raised became the focus for this second self-study reflective cycle of action:

1. What will I do to involve children in the portfolio process?

2. Will involving children in the portfolio process make a difference to teacher practices and children's learning?

3. What are the benefits of conducting action research as a means to improve my pedagogical practices?

The area of practice I have investigated is my role in involving children in the portfolio content selection process. In order to implement a solution (Appendix B) and change my teaching practices, two important issues needed to be considered:

- The ways in which children were already involved and discussions with them on how they could contribute to their portfolios.

- Teaching team collaboration on ways of encouraging children to contribute. 


\subsection{How were children contributing to their portfolio?}

At the start of the research children and their parents very rarely contributed to the portfolios although some parents had written comments in them when they had been sent home. I thought and assumed that by making them readily obtainable that children and their parents would become more involved and add photographs, stories and more comments to the portfolios. However, the data confirmed that children and parents contributing to the content and compiling process continued to happen sporadically.

When I interviewed the children at the beginning of the study I did not specifically ask them if they would like to choose what went into their portfolios. In hindsight this was an important question that I should have asked children and their parents. However some children did tell me how they had contributed:

Lynne: "Is there anything else you would like to tell me about your portfolio"?

Luke Skywalker (4. 6 years): "My Mum is in it I taked it home my Mum helped me to draw a picture to put in it".

Lynne: "Can you tell me about your portfolio"?

Charlotte (4.3 years): "It's got lots of paintings. I like to take photos of things. My Mum puts photos in there”.

Lynne: "Can you tell me what is special about your portfolio"?

Dale (4.6 years): "I like putting stuff in it. There is still some white there (pointing at blank scrapbook pages) needs to be more things put in it.

Lynne: "Can you tell me if you like to take your portfolio home”?

Maya (3.11 years): "I like to keep it and put other photos in it" (Interviews 4$5 / 05 / 06)$.

I did not ask parents if they would like to choose and put artefacts in their child's portfolio when I interviewed them. Although Tina (parent) indicated she wanted to add to Jack's portfolio when I asked:

Lynne: Are there any further comments you would like to make?

Tina: "Really keen to add photographs and stories of Jack at home or on holiday or to email photographs to be included" (Interview 5/05/06). 
The data from the discussions I had with children when looking at their portfolios and the observations I collected demonstrated that children wanted to be involved in selecting the content. Some children were asking for photographs to be added that were important to them which would allow them to revisit the photographs as they desired.

Tengis (4.9 years; English as a second language; 20/7/06) is sitting in the book corner looking at his portfolio. I sit down beside him. Tengis shows me the pictures of his family (here and overseas), his house and his friends that live near him. He points to each photo and tells me their names. Tengis continues turning the pages looking at the photos in the learning stories. Tengis points to one of photos smiles and says"Boyzone". I reply "Yes that is your good friend Boyzone soon he will come back to Preschool" (he is away on holiday). (Observation, 20/07/06).

Later in the day I told Tengis's Mum how proud he was showing me the photographs in his portfolio book. She discussed that they had put them in together and how important his book is to him. Tengis was using his portfolio to make connections and links between his family and experiences here in Aotearoa/New Zealand and his Dad and brother in Mongolia (Ministry of Education, 1996a).

As discussed in chapter 4 , I had made changes to my teaching practices and was trying to involve children in the process of compiling their portfolios. I wanted to capture and document their voices, their views and thinking about their learning as the following learning story demonstrates:

Maya (3.12 years, 5/09/06): you chose to look at your portfolio sitting down at the table. I ask if I could look at it with you. You turn the pages looking at the stories and the pictures, when you get to the story about climbing you ask me to read it to you. After reading the story you continue to turn the pages. Maya: "Here is my painting I put green there and there (pointing) and I put pink everywhere I remember that". You turn to the story about building with the blocks pointing to the picture you say Maya: "that's when I had my brown skirt on and we were knocking down the tower me and Christina". "Face painting I am a party girl". 
Lynne: "You painted your own face and it was great; when your Mum picked you up she thought you looked awesome. Your Mum asked me if I had taken some photos and could put the story in your book".

Maya: "You need to put more things in Lynne".

Lynne: "You could put things in maybe photos and stories from home".

Maya: "When I do a drawing I can put it in there".

Lynne: Yes you could choose what you want to put in".

Maya: "I know how to" (you show me how by opening the top of the sleeve in the clear file). "Now I will look at my other one" (portfolio that is completely full).

Maya you continued to talk to me and look through your portfolio for the next half an hour. During this time Dale, Flora and Emilie asked to look at your portfolio and share in the discussion revisiting your previous play and learning experiences. (Observation, 5/09/06).

Later that day Maya drew a self-portrait and put it into her portfolio. Over the next few days Maya continued to put in drawings and paintings that she created specifically for adding to her portfolio. I reflected on this process and documented my thinking (research journal; 8/9/05). It seemed Maya was exploring the concepts of power, control and ownership; what it means to be able to choose what she wants to put in her portfolio and perhaps why she selected that particular piece of artwork

The other teachers also asked children if they would like to contribute. When I interviewed the teachers $(14 / 8 / 06)$ after the portfolios had been out in the centre for three months Penny identified a number of changes to her practice and how she was trying to get parents and children involved choosing and adding artefacts.

Penny: "I find parents are looking at them more often and some are adding things from home. I have been showing and discussing with the children the stories I have put in to get further input from them to extend their learning. Also asking children what they want to put in their books". (Interview, 14/08/06).

When I interviewed Amy the next day (15/8/06) she discussed trying to include the 'child's voice': 
Amy "I try to put the children's voice in their portfolios".

The opportunity for children to select artefacts for their portfolios arose when children asked to have specific photographs taken of them and teachers documented their views, their achievements and their learning. Jane (teacher) was encouraging children to contribute to their portfolios using the photographs of children engaged in play:

Iris (3.6 years: 4/9/06: Jane) you are working at the play dough table beside another child; you say "my kitchen is so messy how can we clean it"? You start to clean your kitchen by cleaning out a yellow tube using a spoon to get the play dough out (good thinking). As you work you talk about the things you are doing. You decide that you want to make a heart the other child is using the heart cutter so you ask

\section{"Can I use the heart after you please"?}

Soon it is your turn and you start to make your heart. I take a photo of you; you turn to me and ask me to take a photo of the heart "Would you like me to put it in your book"? You nod after I have taken the photo you ask me "Is it in my book now"?

I explain that I need to print the photo and put it into your book when it comes back to Preschool.

“It's at my Daddies" you reply. (Observation, 4/09/06).

This story illustrates that children were able to develop an understanding of the value of their learning when their views were listened to and documented. This provided children with the possibility to have more shared control and ownership of their portfolio (Herbert, 2001).

After analysing the interviews with the children after the portfolios had been accessible for three months I came to the conclusion that most of the children did not have an understanding that they could choose and add artefacts to their portfolios. My actions and practices were controlling and disempowering for children. I was not sharing the power and control of adding the contents and compiling the portfolios with them. For example, although I was listening to the children and developing an understanding of their views on their portfolios I was not asking probing open-ended 
questions to find out why a particular artefact they added was important to them (Goffin, 1989). I reflected on how I could authentically contribute to building a culture of practice (Wenger, 1999) within the centre of responsive power sharing and empowerment (Claxton \& Carr, 2004; Ministry of Education, 1996a, 2004). For this to happen I needed to discuss my findings with the teaching team and work collaboratively to change our practices in order to effectively involve children in the process of compiling their portfolios.

\subsection{Teaching team collaboration and discussion}

The focus of my multiple roles as the supervisor (the professional leader in the centre), teacher and teacher/researcher is to support the teaching team's professional development and their shifts in thinking about their practices and children's learning (Herbert, 2001; Rodd, 2006). What was really exciting for me at the end of cycle one was interviewing the teachers and hearing their enthusiastic responses (See Chapter 4) about the changes to their practices. In particular this focused on how they were now using portfolios and that they would like to share the ownership of portfolios with children and their families/whānau.

After analysing and comparing their responses with mine it verified congruence of the changes we had made to our teaching practices; the progression of our thinking and the development of a shared sense of purpose to support children's learning. Therefore it was important as a team to clarify the implications of the findings of cycle one and how we could develop a culture of responsive power sharing within the centre (Anning \& Edwards, 2000; Rodd, 2006).

At the staff meeting (29/08/06) I disseminated my findings on the first action cycle. I discussed how the research process had provided me with an understanding of children's thinking about the ways they had contributed or wanted to contribute to their portfolios. More importantly I learnt that if children are involved in telling their stories it provides them with the opportunity to think about their own thinking (metacognition) and the learning process (Rogoff, 1990; Rogoff, \& Lave, 1984). I wanted children's contribution to their portfolios to become a reality for them and be and part of the everyday practice of compiling portfolios. Current literature suggests 
(Hatherly, 2006; Herbert, 2001; Ministry of Education 2004; Te One, 2000, 2002) that if children share ownership and decide the content of their portfolios they begin to self-assess their learning and think about why the artefacts they choose are important to them.

The teaching team could see the benefits for children's learning after making the portfolios accessible. They were enthusiastic about shared ownership and having children and parents contribute. Together we developed a shared vision to work towards; to develop a culture and community practice of shared portfolio ownership with children, parents and whānau. To make real this vision we needed tools to support the changes to our practices. The limited amount of information and technology (ICT) tools (two computers a digital camera and a printer) that we used to support the documentation of children's stories about their learning posed a significant barrier to how we wanted to use the portfolios with children. This problem needed to be addressed in order to fully implement the action strategies and the solution for the second action cycle (Appendix B). This lead to increased ICT capability.

\subsubsection{Increasing our ICT capability}

In August 2006 a parent had donated a laptop to the centre. It needed programmes added to enable the camera to be downloaded and learning stories typed. I spoke with Jean (my manager) and there was money in the budget to do this. The laptop was outdated therefore it was not possible. Jane (teacher) rang the ICT department at the institute we are attached to and they had a laptop that they were able to donate.

After having a discussion with Jean (manager) about my action plan to involve children in the portfolio process, she said that there was money available in the budget to fund the purchase of a second digital camera and a new laptop not only for my centre but the other five she manages. It took until the end of November 2006 to increase our ICT capability. We now had two laptops, two digital cameras and two desk top computers, tools needed to support the changes to our practices and children's learning.

The lack of ICT tools to support teachers practices, their learning and children's in early childhood care and education (ECE) centres and the funding for these; are not 
only issues for my centre but across the ECE sector (Bolstad, 2004; Mitchell, \& Brooking, 2007).

\subsection{Involving children in the portfolio process: The solution}

In the week prior to beginning action cycle two I had planned a parent evening $(8 / 11 / 06)$ to discuss the insights I had gained in the first action cycle and to explain cycle two. I cancelled this as only two parents could attend. At first I was worried that it was due to a lack of interest. After further discussion I discovered time was the problem due to exam and study commitments. However, I had numerous discussions with parents about the findings of the first action cycle and explained how I was going to involve children in the portfolio process. I began to put the strategies in place and gather the data on the following week (13/11/06). The first action strategy I tried was to wait until children asked me or the other teachers to take a photograph of them to add to their portfolio. This was not happening so I tried a different approach. I asked several children if they would like to tell me their stories to go with the photographs that I had taken of their learning to add to their portfolios and they said "no". However, I continued with this strategy and I began to experience some success:

Today at rest time (16/11/06) Penny (teacher) and the children she was working with drew pictures on the magnetic white board. After they had finished I asked Sarah (child) if she would like to download the photo and she could tell me her story to put in her portfolio. We set up the laptop and down loaded it then Sarah told me her story. Pointing to the drawings on the screen Sarah you told me

Sarah: "This is a tiger with a fat face from Lauri. An owl from Penny (teacher) owl starts with o. That is Maya's horse. That is Emilie's butterfly. Flora drawed that jellyfish, I think that's it". (Observation, 16/11/06).

Next came the time consuming part due to our lack of ICT tools. I had to copy the story onto a memory stick, then on to the desk top computer to print it off. The wait however was worthwhile when I saw Sarah's sense of pride and accomplishment of being able to see her story and put it into her portfolio. Sarah then showed the story to teachers and children. Some of the other children wanted to tell their stories. There 
were no photographs of them on the laptop or camera. By the time I did get photos on to the laptop a considerable amount of time had passed; the children were involved in play and they had no interest in telling me their stories.

\subsubsection{The use of cameras as a strategy}

I downloaded the photographs I had taken of children using their portfolios (93 images) as part of the data gathering and showed them as a slide show on the laptop. This was successful. The photographs were a powerful tool to stimulate children's discussion on their thoughts about their learning and their views about their portfolios. I decided to let children use the digital camera to take photographs as a way of empowering them to contribute to their portfolios. This strategy was influenced by reading the report, Listening to young children: the mosaic approach (Clark \& Moss, 2005). The findings of the study demonstrated that children's use of cameras was a powerful way for children to gain an understanding of control, choice and having their thoughts listened to by adults. The results showed "children chose which photographs they wanted to be in their books" (p. 24). The same cannot be said for the results of this study. Children did not choose photographs to be added to their books. The children did have fun, they seemed to enjoy being in control of the camera and being able to choose what to photograph. Over a period of nearly two weeks 354 images were taken and there were a number of interesting photographs. I did gain an insight into what was important to children from their perspective from the discussions we had about their photographs. However, the children did not ask for any of the photographs to be added to their portfolios. It was not part of their agenda.

29/11/06: I was downloading the camera of the photographs the children had taken onto the laptop Flora, Emilie and Maya came to look at the photographs that were down loading.

Flora: "I love my photos of Preschool".

Emilie: "I took photos of everyone's face and the deck because I wanted to"

Lynne: "Can you tell me what it is you like about the deck".

Emilie: "Going down the slide and pole".

Maya: "I didn't because I didn't want to" (take photos).

Flora: "I made a kite and it was broken so I put it in my portfolio"

Emilie: "I took a barrel swing photo". 
Maya: "Look, there is me, there is me you point to the screen".

Lynne:" Is there any photos you have taken that you would like to add to your portfolios"?

"No" said Flora, Emilie and Maya.

Perhaps it was the Xmas tree and the box of decorations that was brought in to be set up was that was the cause of the loss of interest. (Observation, 29/11/06).

\subsection{Children explore the concept of portfolio ownership}

It was during this cycle that I collected some exciting data of the children continuing to explore their understanding of portfolio ownership that had begun to develop in the first cycle.

Lucy (4.6 years) today (2/11/06) you brought in a clear file inside was a story that your Granddad had made with you about the story of your stay at his farm.

You tell me "this is a book not a portfolio".

You share with me your story. When you finished the story I explain how while you have been away I had finished all the pages in your portfolio (scrapbook) and have started a new one (clear file).You go to the container find your new portfolio and look at the photographs.

You seem to be very pleased with your new portfolio. After you return it back to the container you pick up the story of your trip with a beaming smile you say to me "this is my other portfolio". (Observation, 2/11/06).

I was really intrigued when Lucy told me that her book was not a portfolio. I did wonder why her opinion changed after she looked at her new portfolio as it was a clear file rather than a scrapbook. Was it the similarities between the covering and the contents that had made her changed her mind? I believe it was her understanding of the connections and links between the contents and her involvement in the process of making her own book that contributed to the changes in her thinking.

I observed Lucas exploring his knowledge of ownership with a visiting teacher from China. 
24/11/06: Lucas (3.7 years) you were listening to Helen (teacher) asking Amy (teacher) if she could look at Charlotte's portfolio.

"You can't look at it you have to ask Charlotte" you say to Helen.

Amy explains to her about portfolio ownership and asking the child if their portfolio can be looked at. Amy suggests to Helen that perhaps she could ask you to look at your portfolio.

Helen asks you "yes" you reply and enthusiastically share your portfolio with her. (Observation, 24/11/06).

Lucas transitioned to centre towards the end of action cycle one. I believe that his understanding of the concept of portfolio ownership developed as it was now part of the culture of the centre.

\section{6 "Portfolios are all about me"}

19/7/06 Iris (3.5 years): Looks at her portfolio points to the pictures and says to Amy "Look me here, here, here, lots of me".

5/09/06 Emilie (4 years): You tell me "I looked at my portfolio last night with my Nana".

Lynne: "That was good to take it home and share and now you are sharing it with your friends Flora and Maya".

9/10/06 Kitty (4.5years): Is looking at her portfolio with Anne (teacher) pointing to the photo "its good there is photos of me because I want to look at them when I'm 8'.

The finding of the data collected throughout this study provides the evidence demonstrating the significance of portfolios for children. Portfolios are all about the children, their friendships and relationships with the people places and things that are important to them (Ministry of Education, 1996a, 2004) Portfolios celebrate their achievements and their learning alone, with and alongside their peers. Portfolios are a powerful tool and the photographs are important to children as they provide a visual reminder of their learning experiences and a progression of their thinking, as the following learning story demonstrates

29/5/06 Penny: Luke Skywalker brought his book opened to the 'Electricians' page. "I wanna do this Penny". "I tell him we had to throw 
away those old electric radios. Amy (teacher) goes out to see and they are gone, but she finds another old cd player. She asks Luke Skywalker if he wants to take it apart. He acts very excited and runs and puts his book away. Amy brings the cd player in and a screwdriver. Luke Skywalker starts unscrewing things and other children join him. He and Emilie spend the most time. They work well together, one holding the player, the other using the screwdriver. Luke Skywalker stayed doing this for most of the morning. Amy helped him and they took lots of bits out and off. Luke Skywalker kept coming over to show me what he took off. As he was working, he asked if I was going to take photos and put it in his book. (Observation, 29/05/06).

Making portfolios accessible to children (chapter 4) has opened up the possibility for children to revisit and repeat learning experiences that are meaningful to them (Alcock, 2000; Ministry of Education, 1996a; 1998, 2004; Te One, 2000)

\subsection{The challenges of improving my practice}

At the start of action cycle two during the first few weeks I encountered a number of difficulties and challenges. The strategy I implemented of waiting for children to ask for artefacts to contribute to their portfolios proved to be unsuccessful. What I was trying to implement to bring about changes in my teaching practices to support children's learning was proving to be ineffective. I wanted to work with children and document their views in an authentic way (Ministry of Education, 2004; Dahlberg \& Moss, 2005; Carr, 2002; Clark \& Moss; 2005; Edwards, Gandini \& Forman, 1998).

I tried a different approach. When I was taking photographs and documenting children's learning I invited children to tell me their stories. I wanted to capture their voice rather than my voice documenting what I believed was happening for them, so it became their story not my interpretation of their thinking. At first this was challenging as the children chose not to tell me their stories. On reflection, I was interrupting their flow of play using "the question and answer pattern so common in pedagogical practices, a pattern which can easily have the effect that the child has got nothing to say as she or he is forced into a predetermined position" (Dahlberg \& Moss, 2005, p. 106). 
I changed my approach by involving them in the process of downloading of the photographs on to the laptop or the computer then documented their ideas (5.3), This is a more meaningful and valid way of working with children. Although at times this was not always possible due to staffing or ratio constraints to document children's stories at the time as the following observation demonstrates:

1/12/06, Lynne: I was outside pushing children on the swing. Maya came to me, holding out her drawing said to me "Lynne look at the picture of my cat" Lynne: I look at the drawing and reply "cool picture Maya would you like to put it into your portfolio?"

Maya: "Yes"

Lynne: "When I am working in the office on your book you could tell me the story about the drawing of your cat and we could type it on the computer".

Maya: "I can do that"

Lynne: "Great Maya”. (Observation, 1/12/06).

Unfortunately the following day I was away at a research conference and on then on leave so the story was not documented. The difficulties and the challenges that I encountered led me to question my capability as a teacher researcher because I was experiencing conflict in my role. I had to consider whether I was trying to make too many changes too quickly because I was excited by the possibilities for children's learning (Anning \& Edwards, 2000).

\subsubsection{Supporting children's involvement in the portfolio process}

I continued to try different strategies to encourage children to contribute. I used the video camera function on the digital camera to record children's learning to replay stories back to themselves on the laptop. This proved to be very popular and children would watch the video repeatedly. They would ask their friends, teachers and parent's to watch their video with them. I copied these videos on to compact discs (cd's) for children to take home to share with their parents and whānau.

6/12/06 Sarah Charlotte and I (Jane teacher) were sitting in the sun Sarah told me that her Uncles cat had died. Then we started talking about her uncle, Charlotte talked about her cat. Sarah then started to tell me about a special dance she and her sister had done; that she wore her special dress- 
Sari and used sticks.

I asked if she would like to show me the dance and I also asked if our rhythm sticks would do. Sarah and Charlotte went inside to see if they would be ok. They came out and I asked if I could film the dance.

Sarah said "yes".

Sarah and Charlotte do the dance Sarah is the leader and she is clear about what she wanted Charlotte to do. Sarah and Charlotte seemed to really enjoy watching themselves on the computer after it was down loaded. (Observation, 6/12/06).

I added my comments to the story: I have copied the dances on the compact disc (cd) as they were too big to email I hope you and your family enjoy watching it. Sarah you may like to have your comments recorded below of what you and your family thought of the cd what fantastic dancing Sarah and sharing your culture with teachers and children.

The teaching strategies, the use of the digital camera and the teacher's interactions supported children's dispositions to participate, to revisit their thoughts and ideas through engaging in reflective discussion about their play. Children were beginning to develop their disposition to self-assess their learning (Carr, 2001; Ministry of Education, 1996a, 2004; Paley 2004).

23/11/06 Flora (4.3 years): you are at the art table working on a drawing beside you is a kite as I sit down you say to me holding up the kite

Flora: "I am going to ask Amy (teacher) to put this in my portfolio".

Lynne: "Can you tell me why you would like to add your kite to your portfolio".

Flora: "the string came off and I wanted to put it in my portfolio as I want to keep it”.

Lynne: "Maybe you could put the kite in your portfolio".

Flora you get your portfolio and put in your kite. (23/11/06).

\subsubsection{Making a difference to teaching and learning}

There has been a significant impact on my teaching practices as I have encouraged and supported children to chose and add the contents to their portfolios. At the start 
of the second cycle my vision and the vision of my colleagues was to develop a culture and community of practice of shared portfolio ownership (Alcock, 2000; Claxton \& Carr, 2004; Fleer, 2003, Herbert, 2001; Rogoff, 1990; Rodd, 2006; Te One 2000). The questions that I have explored are still left unanswered as new questions have emerged. This is a characteristic of action research (McNiff \& Whitehead, 2005). I will continue to make changes to my practices to encourage and support children to contribute and to "own" their portfolio. This vision has not been fully realised. It was never an expectation that it would be as eight weeks is not enough time to radically change completely the purpose, content and the ownership of the portfolios in the centre.

Engaging with action research has led me to critically question my role as a teacher and how my actions, interactions and practices impact on children learning and my colleagues learning and teaching practices. It has provided me with valuable insights for making sense of and understanding my practice. I have learnt through the research process the importance of time and the value of standing back and taking the time to deeply reflect. As I improved my practices I began to understand the significance of developing a pedagogy of listening (Dahlberg, \& Moss, 2005, Clark \& Moss, 2005) through making the time to really listen and understand children's parents and teachers' thoughts and views. Change takes time and the lasting effects of changing one's thinking and practice depends on how adaptable and responsive I am to change (Mc Niff \& Whitehead, 2005; Rodd, 2006).

\subsection{Summary}

The data and the findings confirmed to me that my role as the teacher is to help children and their families to take ownership of the portfolios. The importance of choosing and adding artefacts that are important to them to make connections and links between home and the centre has been a focus. My role as a teacher/researcher is to improve my practice and my learning by making the connections and links between theory and practice. Chapter Four and Five have explored the process of making portfolios accessible and involving children in their portfolios. In the next chapter, discussions focus on my role as the teacher-researcher and my findings on the challenges and benefits of conducting self-study action research. 


\section{Chapter Six}

\section{Teacher Researcher}

\subsection{Introduction}

This chapter examines and presents my findings on the challenges and the success of conducting self-study action research. The main aim of this study was how I could improve my portfolio assessment practices as a teacher. The first action cycle focused on putting my action plans in place and learning how to conduct action research. In the second cycle of the action research I began to understand in more depth my role as teacher researcher and the potential significance of the study. I was now more aware of how it has influenced my teaching and learning. This chapter examines and presents my findings on the challenges and the success of conducting self-study action research.

\subsection{My changing role from teacher to researcher}

"This research study explores my journey as a
teacher/researcher of how I improved my practice and my
learning by making children's port folios accessible and how I
involved children in the portfolio process" (Reflective journal,
12/10/06

At the beginning of my research journey while completing the ethics application form and reading the literature on conducting research with children I learnt that there were a number of critical issues I needed to question and include in the research process. These included:

- To state my values, beliefs and views of children as participants;

- Is there shared power between me as the teacher researcher and the participants in this study?

- Whose voices are heard in the data presentation? Have I included children's, parents, whānau and teachers voices? (Bone, 2005; Cullen, Hedges \& Bone, 2005; Danby \& Farrell, 2004, Fasoli, 2003; Sorin, 2003). 
I reflected on my beliefs and views of children. I believe that the children I work with and alongside are competent and confident learners (Ministry of Education, 1996a). I wanted to capture their voices (Carr, 2000; Clark \& Moss, 2005), in my research to ensure a sharing of power in the data collection and presentation. My views on children are influenced by the socio-cultural and ecological theories of Lev Vygotsky, (1978) and Urie Bronfonbrenner (1979). These theoretical perspectives underpin Te Whāriki (Ministry of Education, 1996a), which in turn underpin my pedagogical practices and perspectives on teaching and learning (Hedges, 2003, Ministry of Education, 1996, Smith, 1992, 1998; Wenger, 1999).

Before the start of the first action cycle, when thinking about how I was going to conduct my interviews with children, I thought about getting a zany hat. When I was wearing the hat the children would know I was in my role as the researcher. I looked around to find a zany hat. Fortunately I was pleased I could not find one. I began to critically reflect on, and question my actions: Why did I want to distinguish my role as the researcher, as being different from my role as the teacher? I realised if I wanted to ensure a sharing of power and the children's voices were being heard then I should not be making any role distinction.

\subsection{Teacher frustrations}

As the professional leader in the centre I have found one of the most difficult and frustrating aspects of being a teacher researcher was trying to take the time I was entitled to for gathering data. There were several reasons why this proved difficult:

- The spontaneous nature of children's play: I could not plan a specific time for gathering the data on children looking at and using their portfolios throughout the day, as this was child initiated. My capacity to be responsive was constrained by other responsibilities.

- The inside/outside duty roster: If I was the outside teacher working with the children then it was impossible for me to collect any data about the children's use of their portfolios. 
- The time to reflect and write up my reflections: Most of my journal entries were written retrospectively either traveling to, and from the centre or in the evenings.

- The auspice of the centre

As the centre is attached to a tertiary institution, at each semester vacation the numbers of children attending lowered. Towards the end of the vacation and the start of each new semester we are busy settling transitioning children. Gathering of the data for the first cycle coincided with a break; there were seven new children and their parents to settle into the centre. Gathering data for the second cycle coincided with the exam period and the summer semester many of these issues continued to be a challenge.

- Responsibilities to staff

My assistant supervisor went on extended leave for three months two weeks prior to the portfolios becoming accessible (15/05/2006) I was covering her teaching position using two relievers (one trained and one untrained) till her return (14/08/2006). Penny (teacher) went on a year's unpaid leave overseas during the second cycle. Her position was covered using untrained relievers until December when a graduating teacher could take on this contract position.

- Recruitment and retention of staff

A characteristic of this centre are the recurring recruitment and retention issues particularly the problems it has to recruit trained teachers. Not only has it been a problem over the period of this study it has been an issue for a number of years. These issues are not uncommon in a number of care and education centres (Mitchell \& Brooking, 2007).

In my role as the researcher, and because conducting this research is for a formal qualification it was important that I collected the data. As the data collection was vital to this study; I needed assistance in gathering some of the data. This raised a crucial question. Could I use observations collected by other teachers as data? McNiff and Whitehead (2005) argue:

This issue can be tricky, because interpretation involves issues about validity, so it becomes a political 
question about who has the right to interpret the data (p. 66).

I do not work in the centre in isolation; I am a teacher and a member of a teaching team. As a part of our everyday practice we work together collaboratively gathering written observations and photographs of the children for their portfolios. The parents had all agreed that this material could be used for the additional purposes of this research.

I gathered the data on my actions, practice and learning. However I decided to include the teachers' data on children's use of the portfolios and their learning. This would provide multiple perspectives of what was happening for children. It also enabled me to triangulate the data; comparing and contrasting my perceptions of the data with the insights of the teaching team. (Mc Niff, \& Whitehead, 2005). To ensure validity I analysed, evaluated and interpreted the data the teachers gathered. I cross checked this interpretation with the teachers (Cohen, Lawrence \& Morrison 2000,).

\subsection{The triumphs of the teacher researcher}

Time has been a recurring theme throughout this study is has been constraining and challenging. However making the time to engage in self-study action research has provided me with the time to constantly critique and reflect in-depth on my teaching practices and these influence children's learning. I have become a producer of research as well as user of research (Rodd, 2006). The shifts in my thinking and understanding of the research process have led me to develop a capacity for systematic critical enquiry.

A further benefit of conducting this action research study is that is has promoted within the centre a community of learners and an enquiry approach to teaching and learning. As Meade, Ryder and Henriod (2004) argues:

Communities of inquirers stimulate growth and development of communities of learners within centres, within local communities or amongst members of professional communities (p. 3). 


\subsection{The education review office returns}

In March 2004 The Education Review Office (ERO) conducted a review of the centre (see chapter 1). Their report identified making children's portfolios accessible an area for improvement. This official identification of the issue together with my concerns provided me with the impetus to explore ways to improve my practice and make portfolios more accessible to children. In March 2007 ERO returned to conduct their three yearly scheduled review. In this report (ERO, May 2007) the improvement of assessment practices (portfolios) is acknowledged as an area of good performance:

Portfolios are attractive comprehensive records of children's participation in the programme. Children can freely access their portfolio and they are starting to add their own contributions to them. Teachers report that children now have a stronger sense of ownership of these records. Positive features of these planning and assessment documents include: narrative observations of children's learning that over time, show greater complexity in the use of this approach; embedded and explicit links to Te Whāriki; a strong focus on recording children's conversations and ideas through the child's voice; an holistic view of the child's interests and learning; and the increasing use of observations of learning in group contexts (p. $8^{2}$ ).

This external review by ERO provided an outsider perspective of the improvements to teaching practices and the benefits for children's learning through making the portfolios accessible and involving children in the portfolio process.

\subsection{Summary}

The findings and the data in this chapter suggest that the role of the teacher researcher is complex and sometimes contradictory. As a novice teacher researcher conducting this action research has strengthened my understanding of the importance of theory, the concept of reflexivity and critical thinking. It has further demonstrated the value of theorising my own practices. Self-study action research is systematic, deliberate and political. It establishes self-critical communities of practice who participate and collaborate in the process. This study has significantly improved my

\footnotetext{
${ }^{2}$ For ethical and confidentiality reasons this ERO report will not be included in the reference list.
} 
pedagogical practices. It has enhanced teachers learning which has in turn benefited the children's learning. Beyond that making the portfolios accessible has strengthened parental understanding of their children's experiences at the centre. We now recognise ourselves as a community of learners. The following chapter will present a synthesis of the action cycles and the conclusions of the previous chapters. 


\section{Chapter Seven}

\section{Conclusions And Future Possibilities}

\subsection{Introduction}

The final chapter of this thesis will discuss the conclusions of the previous chapters and future possibilities for the research questions this study explored. The conclusions presented in this chapter are a synthesis of the major findings, but as is a characteristic of action research as each cycle ended new questions emerged, thus creating a new beginning to further explore as McNiff, Mc Geady and Elliot (2005) propose that:

There are no final answers in life or in action research. As soon as we come to what we think is an answer, a satisfactory situation, the situation itself changes and we are prompted to find new ways of living well in that situation (p. 55).

The purpose of undertaking this research was to find out how I could improve my practice and support children's learning by making their portfolios accessible to them. I chose this focus for my research as my portfolio assessment practices at the time clearly suggested that I was not acting out my educational values, i.e. my belief that children's portfolios should be freely available to them (McNiff, 2002, Whitehead, 1998). In March 2004 the Education Review Office (ERO) conducted a review of the centre. In their report, not having children's portfolios accessible was identified and recommended as an area for improvement. This official identification as one that needed attention along with my concerns provided me with the impetus to explore ways to make portfolios readily obtainable for the children in the centre where I worked and what it means that portfolios are accessible.

\subsection{Portfolio accessibility}

At the start of this research study I began to explore the literature to develop an understanding of what accessible means. The literature described accessible in terms of physical and intellectual accessibility (Barrett, 2005; Cohen, 1999; Helm, Benke 
\& Steinheimer, 1998; Potter, 1999; Smith, 2000; Te One, 2000, 2002). The analysis of the data and the findings confirmed that physical accessibility is more that just having portfolios available for children and their parents to look at. Children need to be able to physically access their portfolios when they wanted to. The importance of the location and how they are stored plays a significant role in their use (Chapter 4). The literature described intellectual accessibility to portfolios meant making them comprehensible to children. Portfolios contain stories of children's learning that use both words and photographs, tools to communicate with their audiences and this creates opportunities for children to reflect on their previously documented experiences or stories. The purpose of the stories is to support, enhance and extend children's learning “they are for the learning and teaching community, documenting the past, and organising the future; describing continuity" (Carr, 2002, p. 28). The data from action research cycle 1 demonstrated that the portfolios were not fully intellectually accessible because I was not fully involving children in the portfolio process. These issues became the focus of the second action cycle. The data collected throughout this cycle provided the evidence of how I involved children in choosing and adding artefacts to their portfolios.

It was during this second cycle that some of the teaching strategies implemented to bring about change emerged as unsuccessful. I was trying to involve children in the selection process the strategy I used of waiting for children to ask to add artefacts to their portfolio proved to be ineffective. I also tried to use the digital camera as a strategy to encourage children to contribute to their portfolios. The children did not ask for any of the photographs that they had taken to be added to their portfolios. The fact that these strategies failed led to some important insights. It was during this cycle I collected some exciting data of children's continued understanding of portfolio ownership. The findings demonstrated that making the portfolios accessible, children's understanding of the portfolio process became part of the culture of the centre. The data gathering and analysis significantly increased my knowledge of children's views about their portfolios. Portfolios are important to children because they are all about them, their friends, and their interactions and relationships with the "people, places and things" which are significant to them (Ministry of Education, 1996a, p.9). 


\subsection{Portfolio ownership}

This research study confirmed the significance of portfolio ownership. It is important to establish whose portfolio it is. Is it the child's, their parents/whānau or the teachers? At the beginning of the first cycle the findings suggested that although the children knew they had a portfolio most of them did not have a sense of ownership. Although they could be viewed on request, the children's portfolios were kept out of sight, in a filling cabinet in the teacher's office. Both purpose and content of the portfolios had been determined by the teaching team. Despite the fact that we believed that the portfolios should be, and were owned by the child (and their parents and whānau), the findings from the first action research cycle demonstrated that the teaching team were in control of that ownership.

After making the portfolios accessible the findings illustrated that some children were very rarely adding artefacts to their portfolios. After implementing strategies to involve children in the selection and compiling process, children began to contribute. Children began to add their artwork and they asked teachers to take and include photographs of them involved in learning experiences or to record their achievements. This created the possibilities for children to have shared ownership and control of their portfolio. The findings highlight that I needed to continue to improve my assessment practices of working with children to facilitate their involvement in the selection of the contents of their portfolios. The findings suggest that I am in the early stages of developing portfolios that are inclusive as they include children's, parents and teacher's voices (Carr, 2001, Edwards, Gandini \& Forman, 1998; Dahlberg \& Moss, 2005). In addition, portfolio ownership is shared rather than controlled by me (Hebert, 2001). Children are active participants as they are involved in the portfolio process and in their own assessment of their learning (Carr, \& Cowie, 2004: Te One, 2000, 2002).

\subsection{The tribulations and triumphs of the teacher researcher}

A criticism of action research is that teachers do not usually of their own accord undertake action research-there is always an external motivation (Johnston, 1994; Mc Taggart, 1991). Conducting action research to critically examine and improve my 
pedagogical practices, theorising my practice to improve my learning and enhance the learning for the children, parents and teachers I worked with has been the real motivator throughout this research journey. An external motivation of conducting a thesis as part of the requirement of the degree of Master of Education was also part of the reason I conducted this action research study.

It has been a constant challenge to be a teacher and a researcher at the same time. This is a complex role that is multifaceted and often contradictory. Some of the difficulties of this role arose during the study include:

- Maintaining ones energy, motivation and enthusiasm for the research study over a period of two years; as a researcher, the professional leader, and a member of the teaching team in the centre has at times been difficult.

- Maintaining my enthusiasm for this study during the collection of and the analysis of data has been immense.

As a novice researcher writing this report it has been a challenge to document my understanding of theory and practice and to establish the links between research, theory and my practice. Elliot (2003) found:

Moving in the space between researcher creates a unique understanding of important issues in Early Childhood Education field. The knowledge and experience of the practitioner can speak to issues important to practice, and research has tools to add a new perspective to those issues (p. 11).

Time has been a recurring theme it has been both a constraint and a benefit. One of the most challenging and frustrating aspects of being a teacher researcher was making the time to gather the data on my actions, practices and learning and the impact of the routines, ratios and rosters, these are the "structural realities that govern teachers day-to-day work in early childhood settings, particularly in childcare centres" (Nuttall, 2005, p. 14). Time has also been a beneficial making the time to engage in self-study action research has provided me with valuable insights and a deeper understanding of the concept of the teacher as the researcher, reflexivity, action research methodology and the research process. 
Action research is not just action. It involves thinking about what we are doing, gathering, and reflecting on data, and modifying our actions accordingly (McNiff, McGeady \& Elliot, 2001, p. 55).

The involvement of the teaching team was a means to improve my portfolio assessment practices and learning. In turn my experiences influenced my colleague's practices and learning. I did not work in isolation in the centre. I have investigated my teaching practices as an individual and as a member of the teaching team that works collaboratively to gather, written observations and photographs of children of the children for their portfolios. The teachers help in gathering some of the data on children's use of their portfolios provided multiple perspectives of what was happening for children. Although I used a self-study action research method it is also a form of participatory action research (McNiff \& Whitehead, 2005, 2006; Mutch, 2005).

\subsection{Reflections six months on}

My thinking on how I can improve my portfolio assessment practices by making children's portfolios accessible to them has been ongoing since 2003. Although I ended the data collection for this research study at the end of December 2006 I have continued to constantly critically reflect on my practices of how I am using portfolios with children, how children are using their portfolios and how I can further encourage children to contribute to their portfolios and the portfolio process. Critical self-reflection is a crucial characteristic of the concept of the teacher as researcher and the reflective practitioner.

From the start of this research study to this present point in time (November 2007) the purpose, the contents and the ownership of portfolios at the centre have continued to evolve. The portfolios are still used as a method of assessing children's learning they still celebrate children's learning and achievements but there is more depth to the stories. Children's learning has become more visible the crucial aspect of children's reflection on their learning, the child's voice is no longer missing the stories contain multiple voices the teachers, children's, parents and whānau. This 
argument if further supported by the current Education Review Office (ERO) report that states

Portfolios include narrative observations of children's play and learning, with a focus on recording conversations and ideas through the child's voice. There is a strong philosophy within the centre team of reflection and continuing study to improve teacher practice (ERO, May, 2007, p. $2^{3}$ ).

\subsection{Suggestions for further research}

Children used their portfolios to revisit and repeat learning experiences and to extend their peers learning (see Chapter 4).

Dale (4.6years: 20/7/06) is working at the art table she says to Amy (teacher): "I am making a Chinese lantern it's in my portfolio".

The story in the portfolio has a picture of the lantern that Dale made that was used to decorate the centre at the end of January 2006.

Amy: replies "You still remember how to make one?"

Dale: points to the picture and says "yes I saw it in my portfolio". (Observation, 20/07/06).

Sprinkle decides he too wants to make a Chinese lantern using the photograph of Dale's lantern and help and support from Dale and Amy.

The analysis and the findings of how children use their portfolios (see Chapters $4 \&$ 5) confirmed the importance of making the portfolios accessible. A further benefit of portfolio accessibility is that it provides children with the opportunity to reflect on, assess and extend their learning (Smith, 2000; Te One, 2000, 2002). When children frequently use and share their portfolios with peers and teachers it can promote critical self-reflection and self-assessment of their learning. (Cohen, 1999; Hebert, 2001; Helm et al., 1998; Potter, 1999). This study did not explore effective teaching practices to support and promote children self-reflection and self-assessment of their learning. Its focus was on making the assessment process more visible and participatory.

\footnotetext{
${ }^{3}$ For ethical and confidentiality reasons this ERO report will not be included in the reference list.
} 
Mutch (2005) writing within an Aotearoa New Zealand context illustrates that the importance of the teacher as the researcher has become a significant issue in educational research; it is now an expectation that teachers will undertake research to improve their teaching practices. This provided me with a rationale to undertake this study. I have learnt whilst conducting self-study action research that the role of a teacher researcher is very complex, challenging and demanding, it is also exciting and rewarding. Therefore a further implication for research is the question; is the expectation of teachers as researchers in reality, too high?

At the beginning of this research study I found that there was a limited amount of literature on action research as a means for improving teachers practice and how this benefits children's learning. During and towards the end of this study there have been action research and research studies published (Meade, 2005, 2006 2007; Ramsey, Breen, Sturm, Lee, \& Carr, 2006; Podmore, Wendt Samu \& the A'oga Fa'a Samoa, 2006) that add to the growth of this body of literature; however further research needs to be conducted on this topic.

\subsection{Final insights}

The word conclusion by its definition suggests an end. However I have found through conducting this action research study that the research questions can never be fully answered. The conclusions presented in this chapter are summaries or a synthesis of the major findings rather than final conclusions. The aim at the centre of this study was investigating how I could improve my portfolio assessment practices and what it means to make portfolios accessible. The findings of this study suggest that making portfolios accessible provides children with an understanding of the purpose, contents and ownership of their portfolios. Involving children in the portfolio process makes visible to children the value of their contributions to their learning. It is vital that teachers critically reflect on the purpose, content and ownership of children's portfolios and develop a shared portfolio vision statement that includes teachers, children, their parents and whānau voices. It is how portfolios are used by a teacher that contributes to children's self reflection and assessment of their learning. 


\section{References}

Alcock, S. (2000). Pedagogical documentation: Beyond observation. Occasional Paper No.7. Victoria University of Wellington: Institute for Early Childhood Studies.

Anderson, G. (1998). Fundamentals of educational research. Great Britain: Biddles.

Anning, A., \& Edwards, A. (2000). Promoting children's learning from birth to five: Developing the new early years professional. Buckingham: Open University Press.

Anning. A., Cullen, J., \& Fleer, M. (Eds.). (2004). Early childhood education: Society and culture. London: Sage Publications .

Austin, M. (1993). Speech notes from NZCER seminar "What is Government's role in early childhood education?" In V. Podmore (Ed.). "What is Government's role in early childhood education?" Wellington: NZCER 39.

Barrett, H.C. (2005). White paper: Researching electronic portfolios and learner $\begin{array}{llll}\text { engagement. } & \text { Retrieved } & \text { November } 2005, \text { from }\end{array}$ http://www.taskstream.com/reflect/whitepaper.pdf.

Bell, J. (1999). Doing your research project: A guide for fist time researchers in education and social science. Great Britain: Edmundsbury Press.

Bodrova, E., \& Leong, D.J. (2007). Tools of the mind: The vygotskian approach to early childhood education. (2nd ed.). Upper Saddle River, New Jersey: Pearson Merrill Prentice Hall.

Bogden, R., \& Biklen, S. (1992). Qualitative research for education: An introduction to theory and methods. Boston: Allyn and Bacon.

Bolstad, R. (2004). The role and potential of ICT in early childhood education: A review of New Zealand and international literature. Wellington: New Zealand Council for Educational Research. 
Bone, J. (2005). Theorising in progress: An ethical journey: Rights, relationships and reflexivity. Australian Journal of Early Childhood, Vol. 30, No. 1, March, $1-5$.

Bredekamp, S. (1993). Developmentally appropriate practice in early childhood programs serving children from birth through age 8: Expanded edition. Washington D.C.: NAYEC

Broadfoot, P. (2000). Assessment and intuition. In T. Atkinson, G. \& Claxton (Eds.), The intuitive practitioner: On the value of not always knowing what one is doing (pp. 199-219). Buckingham: Open University Press.

Bronfenbrenner, U. (1979). The ecology of human development: Experiments by nature and design. Cambridge, Massachusetts: Harvard University Press.

Broström, S., \& Vilien, K. (1998). Early childhood education in Denmark. In T. David. (Ed.), Researching early education: European perspectives (pp. 2536). London: Paul Chapman Publishing Ltd.

Burns, R.B. (1991). Action research: In Introduction to research methods in education (pp. 252-270). Melbourne: Longman Cheshire.

Cameron, M. (2007). Learning to teach: A literature review of induction theory and practice. Wellington: New Zealand Teachers Council.

Cardno, C. (2003). Action research: A developmental approach. Wellington: New Zealand Council for Education Research.

Carr, M. (1990). To inform their discretion: Assessment in early childhood. In A. Begg et al. (Eds.). SAME papers 1990. Auckland Longman Paul, 1991, 228-242.

Carr, M. (2001). Assessment in early childhood settings: Learning stories. London: Paul Chapman Publishing.

Carr, M. (2002). Keeping it connected. In Te Tari Puna Ora o Aotearoa/NZ Childcare Association. Assessment in early childhood education: keeping it complex, keeping it connected, keeping it credible. A series of three papers based on keynote addresses presented at Te Tari Puna Ora o Aotearoa/NZ Childcare Association national conferences (2001, 2002, 2004). 
Carr, M. (2004). Keeping it Credible. In Te Tari Puna Ora o Aotearoa/NZ Childcare Association. Assessment in early childhood education: keeping it complex, keeping it connected, keeping it credible. A series of three papers based on keynote addresses presented at Te Tari Puna Ora o Aotearoa/NZ Childcare Association national conferences $(2001,2002,2004)$.

Carr, M., \& Cowie, B. (1997). Assessment: Why record? Paper Presented to NZARE Annual Conference, December, Auckland.

Carr, M., \& Cowie, B. (2004). The consequences of sociocultural assessment. In A. Anning, J. Cullen, \& M. Fleer (Eds.). Early childhood education: Society and culture (pp. 95-1006). London: Sage Publications Ltd.

Carr, M., \& May, H. (1993). Choosing a model. Reflecting on the development process of Te Whāriki: National early childhood curriculum guidelines in New Zealand. International Journal of early Years Education, Winter, 721.

Carr, M., May. H., \& Podmore, V. (1998). Learning and teaching stories: New approaches to assessment and evaluation in relation to Te Whāriki. Wellington: Institute for Early Childhood Studies, Victoria University of Wellington.

Carr, W., \& Kemmis, S. (1993). Action research in education. In M. Hammersley (Ed.). Controversies in classroom research (2nd ed.) (pp. 235-2.45). Philadelphia: Open University Press.

Clark, A., \& Moss, P. (2005). Listening to young children: The mosaic approach. London: National Children's Bureau.

Claxton, G., \& Carr, M. (2004). A framework for teaching learning: the dynamics of disposition. Early Years, Vol, 24, No. 1, March, 87-97.

Cohen, L. (1999). The power of portfolios. Scholastic Early childhood Today, February, 22-29.

Cohen, L., Manion, L., \& Morrison, K. (2000). Research methods in education (5th ed.).Great Britain: Routledge. 
Cowie, B., \& Carr, M. (2004). The consequences of sociocultural assessment. In A. Anning, J. Cullen, \&M. Fleer (Eds.). Early childhood education: Society and culture (pp. 95-106). London: Sage Publications Ltd.

Creswell, J. (1998). Qualitative inquiry and research design: Choosing among five traditions. Thousand Oaks, California: Sage Publications.

Cullen, J., (1996). The challenge of Te Whāriki for future developments in early childhood education. Delta, 48 (1), 113-126.

Cullen, J., Hedges, H., \& Bone, J. (2005). Planning undertaking and disseminating research in early childhood setting: An ethical framework. Retrieved August 27 2006, from http://www.childforum.com/ec_article_details.asp?REF_NO=5.

Dahlberg, G. \& Moss, P. (2005). Ethics and politics in early childhood education. London: Routledge Falmer.

Dalli, C., Te One, S. (2002). Early childhood education in 2002: Pathways to the future. In I. Livingstone (Ed.). New Zealand Annual Review of Education, 12:2002, 177-202. Wellington: School of Education, Victoria University of Wellington.

Danby, S., Farrell, A. (2004). Accounting for young children's competence in educational research: New perspectives on research ethics. The Australian Educational Researcher, Vol. 31, No. 3, 35-49.

David, T. (Ed.). (1998). Researching early childhood education: European perspectives. (pp. 1-6). London: Paul Chapman Publishing.

Denscombe, M. (2001). The good research guide: For small - scale social research projects. Buckingham, Philadelphia: Open University Press.

Denzin, N., \& Lincoln, Y. (Eds.). (2000). The handbook of qualitative research. Thousand Oaks, California: Sage Publications.

Dyk. J. (2002). Classroom teacher research. Retrieved May 11 2005, from http://www.mcdowellfoundation.ca/main_medowell/current/Jenifer_dyk_p aper.htm\# 
Edwards, C., Gandini, L., \& Forman, G. (Eds.). (1998). The hundred languages of children: The Reggio Emilia approach advanced reflection. (2nd ed.). Greenwich: Ablex.

Elliot, E. (2003). From researcher to practitioner to...?. Retrieved May 12 2005, from http://www.reconece.or/proceedings/elliot922003pdf.

Elliot, J. (1991). Action research for educational change. Buckingham: Open University Press.

Farquhar, S.E. (2003). Quality teaching early foundations: Best evidence synthesis. Wellington: Ministry of Education.

Fasoli, L. (2001). Research with children: Ethical mind-fields. Australian Journal of Early Childhood, Vol. 26, No. 4, December, 7-11.

Fleer, M. (2003). Early childhood education as an evolving 'community of practice' or as a lived 'social reproduction': Researching the taken for granted. Contemporary Issues in Early Childhood, Vol. 4, No. 1, 64-79.

Fleet, A., Patterson, C., \& Robertson, J. (Eds.). (2006). Insights: Behind early childhood pedagogical documentation. New South Wales: Pademelon Press.

Goffin, S.G. (1989). Developing a research agenda for early childhood education: What can be learned from research on teaching? Early Childhood Research Quarterly, (4), 187-204.

Goodfellow, J. (2005). Researching with/for whom? Stepping in and out of practitioner research. Australian Journal of Early Childhood, Vol. 30, No. 4, December, 48-57.

Goodwin, W.L., \& Goodwin, L.D. (1996). Understanding quantitative and qualitative research in early childhood education. New York: Teachers College Press.

Graue, E.M., \& Walsh, D.J. (1998). Studying children in context: Theories, methods, and ethics. Thousand Oaks California: Sage Publications.

Gregson, R. (2004). Teacher research: The benefits and pitfalls. Retrieved October 9 2005, from http://www.aare.edu.au/04pap/gre04828.pdf. 
Hatherley, A. (2006). The stories we share: Using narrative assessment to build communities of literacy participants in early childhood centres. Australian Journal of Early Childhood, Vol. 31, No. 1, March 2006, 27-34.

Hatton, N., \& Smith, D. (1995). Reflection in teacher education: Towards definition an implementation. Teaching and Teacher Education, Vol. 11, No. 1, 33-49

Hebert, E.A. (2001). The power of portfolios: What children can teach us about learning and assessment. San Francisco: Jossey-Bass.

Helm, J.H., Beneke, S., \& Steinheimer, K. (1998). Windows on learning: Documenting young children's work. New York: Teachers College Press.

Herr, K., \& Anderson, G.L. (2005). The action research dissertation: A guide for students and faculty. California: Sage Publications.

Huberman, M.A., Miles, M.B. (1995). Data management and analysis methods. In N.C. Denzin, \& Y.S Lincoln. Handbook of qualitative research. London: Sage Publications.

Irving, J. (1990). Plans for quality review and accountability mechanisms in New Zealand, In T. Wyatt, \& A. Ruby (Eds.). Education indicators for quality, accountability and better practice, (pp. 95-111). Australian Conference of Directors-General of Education, 1990.

Jalongo, M.R., \& Isenberg, J.P. (1995). Teachers' stories from personal narrative to professional insight. San Francisco: Jossey-Bass.

Johnston, S. (1994). Is action research a natural process for teachers? Educational action research, Vol. 2, No. 1, 39-48.

Kemmis, S., \& McTaggart, R. (Eds.). (1988). The action research planner (3rd ed.). Australia: Deakin University Press.

Kincheleo, J.L. (2003). Teachers as researchers: Qualitative inquiry as a path to empowerment. (2nd ed.). London: Routledge Falmer

Kondoyianni, A. (1998). Early childhood education research in Greece. In T. David. (Ed.). (1998). Researching early education: European perspectives. (pp. 57-75). London: Paul Chapman Publishing Ltd. 
Launder, D., \& Dalli, C. (1997). How is my child doing?: Selected case studies of how childcare centres meet the DOPs requirement to discuss children's progress with parents. Occasional Paper No, 2, Institute for Early Childhood Studies: Victoria University of Wellington.

Mac Naughton, G. (2001). Action research. In G. Mac Naughton, S.A. Rolfe,\& I. Siraj-Blatchford. Doing early childhood research: International perspectives on theory and practice (pp. 208-223). Buckingham: Open University Press.

Mac Naughton, G. \& Rolfe, S.A. (2001). The research process. In G. Mac Naughton, S.A. Rolfe,\& I. Siraj-Blatchford. Doing early childhood research: International perspectives on theory and practice (pp. 12-30). Buckingham: Open University Press.

Mac Naughton, G., Rolfe, S.A., \& Siraj-Blatchford, I. (2001). Doing early childhood research: International perspectives on theory and practice. Buckingham: Open University Press.

McNiff, J. (2002). Action research for professional development concise advice for new action researchers (3rd ed.). Retrieved November 6 2005, from http://www.jeanmeniff.com/

McNiff, J., Mc Geady, L., \& Elliot, M.R. (2001). Time to listen: An evaluation. Retrieved April 23 2006, from http:/www.jeanmcniff/com/timetol.htm.

McNiff, J., \& Whitehead, J. (2005). Action research for teachers: A practical guide. London; David Fulton Publishers.

McTaggart, R. (1991). Action research: A short modern history. Australia: Deakin University Press.

May, H. (2002). 'Blue skies': Talk in the 'playground.' In J. Loveridge (Ed.). Delta: Policy and practice in education, Vol. 54, Issues 1\&2, 133-148. Department of Social and Policy Studies in Education, Massey University, Palmerston North.

May, H., \& Carr, M. (1998). An update of Te Whāriki: The New Zealand national early childhood curriculum. In M. Carr, H. May, H., \& V. Podmore. Learning and teaching stories: New approaches to assessment and 
evaluation in relation to Te Whäriki (pp.1-7). Wellington: Institute for Early Childhood Studies, Victoria University of Wellington.

May, H., \& Podmore, V. (1998). Project for developing a framework for selfevaluation of early childhood Programmes. In M. Carr, H. May, V. Podmore. Learning and teaching stories: New approaches to assessment and evaluation in relation to Te Whāriki (pp. 19-31).

Mason, B. (2002). Researching your own practice: The discipline of noticing. London: Routledge Falmer.

Meade, A. (2004). Promoting dialogue early childhood education centres of innovation. Keynote Address to New Zealand Action research Network Conference. July 2004, Christchurch. Retrieved May 12 2005, from://www.minedu.govt.nz/indexcfm.

Meade, A. (Ed.). (2005). Catching the waves: Innovation in early childhood education. Wellington: NZCER Press.

Meade, A. (Ed.). (2006). Riding the waves: Innovation in early childhood education. Wellington: NZCER Press.

Meade, A. (Ed.). (2007). Cresting the waves: Innovation in early childhood education. Wellington: NZCER Press.

Meade. A., Ryder. D., \& Henriod. S. (2004). Promoting dialogue early childhood education centres of innovation. Keynote Address to New Zealand Action research Network Conference. July 2004, Christchurch. Retrieved May 12 2005, from://www.minedu.govt.nz/indexcfm.

Meisels, S.J., Liaw, F., Dorfman, A., \& Nelson, R. F. (1995). The work sampling system: Reliability and validity of performance assessment for young children. Early Childhood Research Quarterly, 10, 272-296.

Merriam, S.B. (1988). Case study research in education. San Francisco: Jossey-Bass.

Ministry of Education (1993). Te Whāriki: He whāriki mātauranga mo nga mokopuna o Aotearoa: Draft guidelines for developmentally appropriate programmes in early childhood services. Wellington: Learning Media. 
Ministry of Education (1996a). Te Whāriki: He whāriki matuaranga mō ngā mokopuna o Aotearoa. Wellington: Learning Media.

Ministry of Education (1996b). The revised statement of desirable objectives and practices in New Zealand early childhood services. Wellington: Ministry of Education.

Ministry of Education (1998). Quality in action: Te Mahi whai hua. Implementing the revised statement of desirable objectives and practices in New Zealand early childhood services. Wellington: Learning Media.

Ministry of Education (1999). The quality journey, He haerenga whai hua. Wellington: Learning media

Ministry of Education (2002). Pathways to the future: Nga huarahi arataki. A 10 year strategic plan for early childhood education. Wellington: Learning Media.

Ministry of Education (2004). Kei Tua o te Pae: Assessment for learning: Early childhood exemplars. Wellington: Learning Media.

Ministry of Education (2005). Setting a positive example. New Zealand Education Gazette: Tukutuku kōrero Vol. 84, No. 2, 7 February 2005, 10-12.

Mitchell, L., \& Cubey, P. (2003). Characteristics of professional development linked to enhanced pedagogy and children's learning in early childhood settings: Best evidence synthesis. Wellington: New Zealand Council for Educational Research.

Mitchell, L., \& Brooking, K. (2007). First NZCER national survey of early childhood services 2003-2004. Wellington: NZCER.

Mutch, C. (2005). Doing educational research: A practitioner's guide to getting started. Wellington: NZCER Press.

Newman, J.M. (1998). Action research: Exploring the tensions of teaching. Retrieved May 12 2005, from http://www.lupinworks.com/article/ar/html.

Nutbrown, C. (1994). Threads of thinking: Young children learning and the role of early education. London: Paul Chapman Publishing. 
Nuttall, J. (2005). Educators and children learning together: Reflections on the early childhood assessment exemplars. Early Education, Spring/Summer, (38), $63-71$.

Office of the Commissioner for Children. (2005). United Nations Convention on the Rights of the Child 1989.

Paley, V.G. (2004). A child's work: The importance of fantasy play. Chicago: Chicago University Press.

Penrose, P. (1993). Take another look tirohia anō: A guide to observing children: He momo ārahi kit e tiro i ngā tamariki. Auckland: New Zealand Playcentre Federation.

Podmore, V.N., Wendt Samu, T., \& the A'oga Fa'a Samoa. (2006). O le tama ma lana a'oga, Ole tama ma lona fa'asinomaga. Nurturing positive identity in children: Final research report from the A'oga Fa'a Samoa an Early childhood Centre of Innovation. Retrieved May 4 2007, from http://www.minedu.govt.nz.

Potter, E.F. (1999). What should I put in my portfolio? Supporting young children's goals and evaluations. Childhood Education Summer 1999, 75, 210-214.

Punch, K.F. (1998). Introduction to social research: Quantitative and qualitative approaches. London: Sage Publications.

Quicke, J. (2000). A new professionalism for a collaborative culture of organizational learning in contemporary society. Educational Management Administration Leadership, Vol. 28, No. 3, 299-315

Ramsey, K., Breen, J., Strum, J., Lee, W., \& Carr, M. (2005). Roskill South kindergarten: Centre of innovation. (pp.25-30). In A. Meade, (Ed.). Catching the waves: Innovation in early childhood education. Wellington: NZCER Press.

Ramsey, K., Breen, J., Lee, W., \& Carr, M. (2006). Roskill South Kindergarten Centre of Innovation 2003-2006: Final research report: Strengthening learning and teaching using ICT. Retrieved July 7 2007, from http://www.minedu.govt.nz. 
Robbins, J. (2002). Shoes and ships and sealing wax: Taking a sociocultural approach to interviewing young children. New Zealand Research in Early Childhood Education, Vol. 5, 13-30.

Robinson, V. (1993). Problem based methodology: Researching for the improvement of practice. London: Dunmore Press Ltd.

Rodd, J. (2005). Leadership in early childhood education (3rd ed).Australia: Allen and Unwin.

Rogoff, B. (1984). Introduction: Thinking and learning in context. In B. Rogoff, \& J. Lave. Everyday cognition: Its development in social contexts (pp. 1-8). Cambridge, Massachusetts: Harvard University Press.

Rogoff, B. (1990). Apprenticeship in thinking: Cognitive development in social context. New York: Oxford University Press.

Rogoff, B., \& Lave, J. (Eds.). (1984). Everyday cognition: Its development in social context. Cambridge, Massachusetts: Harvard University Press.

Schön, D.A. (1983). The reflective practitioner: How professionals think in action. New York: Basic Books.

Schön, D.A. (2003). The reflective practitioner: How professionals think in action. Great Britain: Arena, Ashgate Publishing.

Smith, A.B. (1992). Understanding children's development: A New Zealand perspective (3rd ed.).Wellington: Bridget Williams Books.

Smith, A.B. (1996). The early childhood curriculum from a sociocultural perspective. Early Childhood Development and Care 115, 51-64.

Smith, A.B. (1998). Understanding children's development: A New Zealand perspective (4th ed.).Wellington: Bridget Williams Books.

Smith, A.B., Taylor, \& N.J., Gollop, M. (Eds.). (2000). Children's voices: Research policy and practice. Auckland: Pearson Education.

Smith, A.F. (2000). Reflective portfolios: Preschool possibilities. Childhood Education, Summer, 76, 204-208.

Sorin, R. (2003). Research with children: A rich glimpse into the world of childhood Australian Journal of Early Childhood, Vol. 28, No. 1, March 2003, 31-35. 
Stake, R.E. (1995). The art of case study. Thousand Oaks: Sage Publications

Stefanakis, E.H. (2002). Multiple intelligences and portfolios: A window into the learner's mind. Porstmouth, NH: Heinmann.

Stenhouse, L. (1986). The teacher as researcher. In M. Hammersley. (Ed.). Controversies in classroom research. (pp. 222-234). Buckingham: Open University.

Te One, S.J. (2000). Voices for the record: Three teachers' experiences of compiling and using individual child portfolios. Unpublished masters thesis: Victoria University of Wellington.

Te One, S.J. (2002). Portfolios as an alternative assessment tool. Occasional Paper No. 12. Victoria University of Wellington: Institute for Early Childhood Studies.

Toma, J.D. (2006). Approaching rigor in applied qualitative research. In C.F Conrad, \& R.C Serlin (Eds.). (2006). The sage handbook for research in education: Engaging ideas and enriching inquiry. Thousand Oaks: Sage Publications.

Vygotsky. L. S. (1978). Mind in society: the development of higher mental processes. Cambridge: Harvard University Press.

Weiner, R.B., \& Cohen, J.H. (1997). Literacy portfolios: Using assessment to guide instruction. United States of America: Upper Saddle River.

Wenger, E. (1999). Communities of practice: Learning, meaning, and identity. Cambridge: Cambridge University Press.

Whalley, M., \& the Pen Green Centre Team. (2001). Involving parents in their children's learning. London: Paul Chapman.

Whitehead, J. (1988). Creating a living educational theory from questions of the kind, 'how do I improve my practice?' Cambridge Journal of Education. Vol. 19, No. 1, 1989, 41-52.

Whitehead, J. (1998). Creating a living educational theory from the questions of the kind, how can I improve my practice? Retrieved November 6 2005, from http://www.bath.ac.uk./\%7Eedsajw/writings/livingtheory.html. 
Whitehead, J. (2006). Practitioner research asking and answering, How do I improve what I am doing? Creating a living educational theories of learning evolving in a world of educational quality. Retrieved January 6 2006, from htpp://people.bath.ac.uk./edsajw/

Whitehead, J., \& McNiff, J. (2006). Action research living theory. London: Sage Publications.

Wilks, A. (1993). Assessment of children in kindergartens and childcare centres. Report to the Ministry of Education. Wellington: Ministry of Education.

Wilks, A. (2000). Re visioning assessment as a collaborative venture. Paper Presented to AARE Conference, The University of Sydney, December.

Yin, R.K. (2003). Case study research: Design and methods. (3rd ed.).Thousand Oaks California: Sage Publications. 


\section{Appendices}

\section{Appendix A: Research questions and methods to answer questions}

\begin{tabular}{|c|c|}
\hline Research Questions & Methods/How I intend to answer the questions \\
\hline 1. How do children use portfolios? & $\begin{array}{l}\text { Observations explanations of how children are } \\
\text { using portfolios. } \\
\text { Reflections in research journal } \\
\text { Document analysis } \\
\text { Observations and photographs of making } \\
\text { portfolios accessible } \\
\text { Observations and photographs of how children } \\
\text { use portfolios when they are accessible } \\
\text { Case study }\end{array}$ \\
\hline $\begin{array}{l}\text { 2. What will I do to make children's portfolios } \\
\text { accessible to them }\end{array}$ & $\begin{array}{l}\text { Imagine a solution } \\
\text { Research journal-documenting the process of } \\
\text { making portfolios accessible } \\
\text { Parent evening on accessible portfolios } \\
\text { Discussion with teachers, children and parents } \\
\text { about making the portfolios accessible } \\
\text { Discussion with the teaching team on how I will } \\
\text { make the portfolios accessible } \\
\text { Observations photographs of children using } \\
\text { portfolios } \\
\text { Critical reflection on my practices } \\
\text { What does my observations suggest to me about } \\
\text { what is happening for children } \\
\text { New questions emerge for cycle two }\end{array}$ \\
\hline $\begin{array}{l}\text { 3. Will making portfolios accessible to them } \\
\text { make a difference to teacher practices and } \\
\text { children's learning? }\end{array}$ & $\begin{array}{l}\text { Case study } \\
\text { Reflections in research journal } \\
\text { Discussion with children-the child's voice } \\
\text { Discussions with teachers and parents } \\
\text { Changes to teaching practices after making } \\
\text { portfolios accessible } \\
\text { Evaluating observations of children using } \\
\text { portfolios }\end{array}$ \\
\hline $\begin{array}{l}\text { 4. What are the benefits of conducting action } \\
\text { research as a means to improve my } \\
\text { pedagogical practices }\end{array}$ & $\begin{array}{l}\text { Analysis of observations } \\
\text { Analysis of research journal } \\
\text { Analysis of case study on my teaching practices } \\
\text { and the research process }\end{array}$ \\
\hline
\end{tabular}




\section{Appendix B: Research questions and methods to answer questions}

\begin{tabular}{|c|c|}
\hline Research questions & Methods/How I intend to answer the questions \\
\hline $\begin{array}{l}\text { 1. What will I do to involve children in the } \\
\text { portfolio process? }\end{array}$ & $\begin{array}{l}\text { Observations/explanations of how children are } \\
\text { currently contributing to portfolios } \\
\text { Discussions with the teaching team on what I will } \\
\text { do to encourage children to contribute } \\
\text { Discussions with children on how they would } \\
\text { like to contribute } \\
\text { Critical reflection on my practices } \\
\text { Imagine a solution } \\
\text { Observations and photographs of children } \\
\text { contributing } \\
\text { What do my observations suggest to me about } \\
\text { what is happening for children } \\
\text { Making time to spend with children during the } \\
\text { day and on my non-contact working on their } \\
\text { portfolios with them } \\
\text { Laptop in the centre to download photographs } \\
\text { and encourage children to tell stories } \\
\text { Children to take photographs and choose which } \\
\text { ones to add to their portfolios } \\
\text { Encourage children to tell stories of photographs } \\
\text { they ask to be taken } \\
\text { Try different strategies reflect on effective of } \\
\text { ineffective strategies and practices } \\
\text { Observations of children involved in the process } \\
\text { New questions emerge }\end{array}$ \\
\hline $\begin{array}{l}\text { 2. Will involving children in the portfolio process } \\
\text { make a difference to teachers' practices and } \\
\text { children's learning? }\end{array}$ & $\begin{array}{l}\text { Case study } \\
\text { Research journal reflections } \\
\text { Discussions with children-the child's voice } \\
\text { Discussions with parent and teachers } \\
\text { Further changes to practices after involving } \\
\text { children in the process } \\
\text { Evaluating observations of children contributing } \\
\text { to their portfolios }\end{array}$ \\
\hline $\begin{array}{l}\text { 3. What are the benefits of conducting action } \\
\text { research to improve my pedagogical practices }\end{array}$ & $\begin{array}{l}\text { Analysis of observations } \\
\text { Analysis of research journal } \\
\text { Analysis of case study on my teaching practices } \\
\text { and the research process }\end{array}$ \\
\hline
\end{tabular}




\section{Appendix C: Information sheet for Manager}

Manager Early Childhood Education Services

Kia Ora,

As you know I am enrolled as an M.Ed. student at Victoria University. As part of this degree I am undertaking an action research project as my 3-paper thesis. The research project is to explore ways to make children's portfolios more accessible to children and their parents in the Preschool Crèche where I work. I am writing to you as manager to seek your permission to undertake this research. A copy of my proposal is attached for your information.

The University requires that ethics approval be obtained for such research.

The data collection will involve one or more of the following:

- Observations and photographs within the centre documenting the process of making the portfolios readily accessible and the way the children use them.

- Record keeping of naturally arising discussions with children and parents that illustrate their attitudes and feelings about having the portfolios readily accessible in the centre.

- Discussions with the teachers at staff meetings on the process and benefits for children's learning and improving teaching practice.

Participation in this research will be voluntary. I will be seeking written consent from individual participants. These include: parents, children and teachers. Verbal consent from the children will also be obtained by me and written down. The participants would not be identified in the final report or in any publications or conference papers.

This research is being carried out under the supervision of Dr Carmen Dalli, (phone; 044635168) and Sarah Te One, (phone; 04-4635716) at the Institute of Early Childhood studies, Victoria University of Wellington. You are welcome to contact them for more information about this project. Please do not hesitate to contact me for more information (phone; 04-4635182, day). If you are happy for me to undertake this research in the Preschool, please complete the attached consent form and return it to me.

Sincerely

Lynne Steele 


\section{Appendix D: Consent form for Manager}

I understand and agree to the following: Please tick if you agree.

I have read the information sheet and research proposal regarding this project.

I have been given the opportunity to ask and answer questions and have them answered to my satisfaction.

As the early childhood education services Manager, I agree to Lynne Steele, undertaking research in the Preschool in which she works as the Supervisor/Teacher.

I understand participation in this research is voluntary.

I understand Lynne will be seeking written consent from individual participants. These include: parents, children and teachers. Verbal consent from the children will also be obtained and written down by Lynne.

I understand the participants will not be identified in the final report, publications or conference papers.

I would like to receive a summary of the results of this research when completed Yes No

Your name:

Your signature:

Date: 


\section{Appendix D: Information sheet for teachers}

Teaching Team

\section{Kia Ora}

As you know I am enrolled as an M.Ed. student at Victoria University. As part of this degree I am undertaking an action research project as my 3-paper thesis. The research project is to explore ways to make children's portfolios more accessible to children and their parents in the centre in which we work. A copy of my proposal is attached for your information. During our preliminary discussions on the research project you voiced your willingness to take part in the research as participants. I am now writing to ask each of you individually and as part of the teaching team if you will be a participant in this research project.

The University requires that ethics approval be obtained for such research.

Participation in the project would involve me observing and documenting discussions with you, the rest of the teaching team, children and parents, on the process of making children's portfolios accessible; children using the portfolios; your interactions with children using their portfolios, the benefits for children's learning and improving teaching practices, individually and as part of the teaching team.

Participation in this project is voluntary and you would be able to withdraw at any time without question until the end of the data-gathering phase. In the event of your withdrawal any relevant discussion notes involving you will be removed from the data. Neither you nor the centre will be identified by name and any publications or conference papers based on the research and direct quotes in publications or presentations will not reveal your identity. The attached consent form asks you to nominate a pseudonym.

This research is being carried out under the supervision of Dr Carmen Dalli, (phone; 044635168) and Sarah Te One, (phone; 04-4635716) at the Institute of Early Childhood studies, Victoria University of Wellington. You are welcome to contact them for more information about this project. Please do not hesitate to let me know if you require further information on this project. If you are happy to be a participant in this research project please complete the attached consent form and return it to me.

Sincerely

Lynne Steele 


\section{Appendix F: Consent form for teachers}

\section{I understand and agree to the following: Please tick if you agree.}

I have read the information sheet and research proposal regarding this project.

I have been given the opportunity to ask questions and have them answered to my satisfaction.

I agree to take part and be a participant in this project.

I understand this will involve: being observed at the centre and the documentation of some of my conversations with Lynne Steele the teaching team, with children, and with parents on: the process of making children's portfolios accessible; children using the portfolios; my interactions with children using their portfolios, the benefits for children's learning and improving teaching practice.

I understand that participation in this project is voluntary and I would be able to withdraw at any time without question until the end of the data-gathering phase.

I understand that in the event of my withdrawal any relevant notes will be given to me.

I understand my name will be confidential to Lynne Steele and her supervisors Carmen Dalli and Sarah Te One.

I understand that any publications or conference papers based on the research and direct quotes in publications or presentations will not reveal my identity.

For the purposes of this research I would like to be known by the pseudonym of in order to protect my identity.

I would like to receive a summary of the results of this research when completed

Yes No

Your name:

Your signature:

Date: 


\title{
Appendix G: Information sheet for parents/whānau
}

\author{
Parents/Whānau
}

Kia Ora

As you know I am enrolled as an M.Ed. student at Victoria University. As part of this degree I am undertaking an action research project as my 3-paper thesis. The research project is to explore ways to make children's portfolios more accessible to children, and yourselves as parents and whānau. Portfolios are gathered as a normal part of our practice. They involve observations and photographs of children. As part of the enrolment procedure you have already given permission for teachers to observe and photograph your child. This letter is to ask if this material can be used for the additional purpose of the research. I am writing to seek your permission to make notes about any formal or informal discussions we may have about your child's portfolio over the first year of your child's attendance at the centre. I would like to use your child's portfolio as part of this research. A copy of my proposal is available in the office for you to read.

The University requires that ethics approval be obtained for such research.

Your participation in this project is voluntary and you would be able to withdraw, or withdraw your child at any time without question until the end of the data-gathering phase. In the event of your withdrawal any material involving your child and yourself will not be used. I will respect your child's right to accept or decline to take part in this research. I will be attentive to any signals, non-verbal or verbal, your child may give to withdraw their consent at any time. Neither you, nor your child will be identified by name in any publications or conference papers based on the research; direct quotes in publications or presentations will not reveal your identity. The attached consent form asks you to nominate a pseudonym for your child and yourself.

This research is being carried out under the supervision of Dr Carmen Dalli, (phone; 04-4635168) and Sarah Te One, (phone; 04-4635716) at the Institute of Early Childhood studies, Victoria University of Wellington. You are welcome to contact them for more information about this project. Please do not hesitate to contact me for more information (phone; 04-4635182, day). If you are happy for you and your child to be a participant please complete the attached consent form and return it to me.

Sincerely

Lynne Steele 


\section{Appendix H: Consent form for parents/whānau}

\section{I understand and agree to the following: Please tick if you agree.}

I have read the information sheet regarding this project.

I have been given the opportunity to ask questions and have them answered to my satisfaction.

I understand that consent is being asked for my participation and my child's participation in this research project.

I agree to be a participant in this research.

I agree that my child/the child under my guardianship, (delete as appropriate) may take part and be a participant in this research.

I understand that Lynne Steele, will use the material normally gathered for portfolios in this research.

In addition, I agree that she may make notes of formal and informal discussions I may have about my child's portfolio.

I am happy for her to use my child's portfolio and notes of formal and informal discussions as part of this research.

I understand that my child's participation in this project, and my own, is voluntary and I would be able to withdraw, or withdraw my child at any time without question until the end of the data-gathering phase.

I understand that in the event of my child's withdrawal, or mine, any material involving my child or myself will not be used.

I understand Lynne will respect my child's right to accept or decline to take part in this research and will be attentive to any signals, non-verbal or verbal; my child may give to withdraw their consent at any time.

I understand that neither my child nor I will be identified in any publications or conference papers based on the research and direct quotes in publications or presentations will not reveal our identity.

For the purposes of this research I would like to be known by the pseudonym in order to protect my identity.

For the purposes of this research I would like my child to be known by the pseudonym in order to protect their identity.

I would like to receive a summary of the results of this research when completed Yes No

Your name:

Your child's name:

Your signature:

Date: 


\title{
Appendix I: Information sheet for parents of a case study child
}

\author{
Kia Ora,
}

I would like to invite your child to one of the three case studies that I am undertaking as part of my Masters thesis. You have previously given me your permission for your child to be a participant and for their portfolio to be used in this research project. I would like to use your child's portfolio for the additional purpose of a case study as part of this research.

Participation in the case study would involve:

- Talking with me about your child's portfolio.

-Your child talking with me about their portfolio.

-Written observations and photographs documenting how your child is using their portfolio in the centre alone, with you, peers, teachers and other adults.

The University requires that ethics approval be obtained for such research.

Your child's participation in this case study is voluntary and you would be able to withdraw your child at any time without question until the end of the data-gathering phase. In the event of your child's withdrawal any relevant notes will be given to you. I will respect your child's right to accept or decline to take part in this research. I will be attentive to any signals, nonverbal or verbal; your child may give to withdraw their consent at any time. Your child will not be identified by name, the pseudonym you have previously nominated will be used in any publications or conference papers based on the research; direct quotes in publications or presentations will not reveal your child's identity.

This research is being carried out under the supervision of Dr Carmen Dalli, (phone; 044635168) and Sarah Te One, (phone; 04-4635168) at the Institute of Early Childhood studies, Victoria University of Wellington. You are welcome to contact them for more information about this project. Please do not hesitate to contact me for more information (phone; 04-4635182, day). If you are happy for your child to be a case study participant please complete the attached consent form and return it to me.

Sincerely

Lynne Steele. 


\section{Appendix J: Consent form for parents of a case study child}

\section{I understand and agree to the following: Please tick if you agree.}

I have read the information sheet regarding this project.

I have been given the opportunity to ask questions and have them answered to my satisfaction.

I understand that consent is being asked for my child's participation and their portfolio to be used for the additional purposes of a case study in this research project.

I agree that my child/the child under my guardianship, (delete as appropriate) may take part in this research as a case study participant and their portfolio be used for the purposes of a case study.

I understand that Lynne Steele, will use the material normally gathered for portfolios.

I agree, that in addition she may make notes of formal and informal discussions I may have about my child's portfolio. Written observations and photographs documenting how my child is using their portfolio in the centre alone, with me, peers, teachers and other adults.

I am happy for my child to be a participant and for her to use my child's portfolio and notes of formal and informal discussions as part of this case study.

I would like to receive a summary of the results of this research when completed

Yes No

Your name:

Your child's name:

Your signature:

Date: 


\section{Appendix K: Information sheet for children}

Kia Ora

I am writing a research project for my University work just like your Mums/Dads. My research is going to be about your portfolios and how you use them here and at home and what you think about your portfolios. If you agree I will be talking to you writing things down and taking photographs of you just like I do for your portfolio now. I will write things down and take photographs of you when you are using your portfolios with teachers, your friends, and parents/whanau. This research will let adults know about how children use their portfolios and what they think.

You don't have to talk to me if you don't want to, if, when we are talking and looking at your portfolio, you want to stop talking or go that's okay, if you don't want to answer any of the questions that's okay too. If you are talking to someone else and you don't want me to write what you are saying that's okay. If you don't want me to take photographs of you that's okay too. I will make sure you are safe. I will ask you if you are happy to be in my research and get you to put your name on a piece of paper or draw me a picture to say you are happy to take part in my research.

When I write my research I might write about some of the things you have talked about but I won't use your name so people won't know they are your words. Your parents have said its okay for me to ask you if you want to take part and write about you in my research. You can ask me any questions you like before you say it's okay to take part as a participant in my research.

Lynne 


\section{Appendix L: Consent form for children}

\section{I understand and agree to the following: Please tick or make a mark if you agree.}

Lynne has spoken to me about her research and told me that:

Lynne is writing research for her university work.

Lynne's research is going to be about portfolios, how children use them at Preschool and at home and what children think about portfolios.

Lynne will write things down and take photographs of me when I am using my portfolios with teachers, my friends, and parents/whanau.

If I don't want to talk to Lynne that is okay. If I am looking at my portfolio and want to stop talking or go away that is okay.

If I don't want Lynne to ask me questions, write about me or take photographs of me that is okay.

Lynne will write about some of the things I have talked about but she won't use my name.

The things Lynne writes about me that is not put in my portfolio, will only be seen by her, her teachers Carmen and Sarah and will be kept private.

If I have any worries or questions about her writing, talking with me, or photographing me I can talk with her about that.

I am happy for Lynne to use my portfolio and write about me using my portfolio I will write my name/draw a picture below.

I agree for Lynne to use my portfolio and write about me

agree (Child) 


\section{Appendix M: Open-ended interview schedule for teachers, children and parents}

Questions for teachers before portfolios are readily accessible

1. Over the past 12 months how often have you sent the portfolios of the children in your group home?

2. Since January 2006 have children asked you if they can look at their portfolios at the centre?

3. Over the past 6 months how often have children asked you if they can take their portfolios home?

4. Over the past 12 months how often do parents ask you if they can take their child's portfolio home?

5. Since January 2006 how often have you sat down with a child and looked at and talked about their portfolios?

6. Tell me how you would like to use portfolios with children?

7. What barriers are there for how you would like to use portfolios with children?

8. Are there any further comments you would like to make?

\section{Questions for parents before portfolios are readily accessible}

1. Over the past 12-months/or period of enrolment how often have you had the opportunity to have your child's portfolio at home?

2. When you are looking at your child's portfolio do you like to look at it alone?

3. Does your child ask you to look at their portfolio?

4. How does your child use their portfolio at home?

5. What does your child say and do when they are looking at their portfolio?

6. If your child's portfolio was readily accessible to you would you

a) look at it weekly/monthly either alone or with your child at the centre?

b) take it home weekly/monthly to look at it with your child and whānau/family?

7. Are there any further comments you would like to make?

Questions for children before portfolios are readily accessible

1. Can you tell me about your portfolio?

2. Can you tell me who do you look at your portfolio with?

3. Can you tell me if you like to take your portfolio home?

4. Can you tell me what is special about your portfolio?

5. Is there anything else you would like to tell me about your portfolio?

\section{Questions for children when portfolios are readily accessible and children are using} them.

1. Would you like to tell me about the photographs/ artwork or stories in your portfolio?

2. Can you tell me if you would like to choose the photographs or artwork to put in your portfolio?

3. Can you tell me what you like best about your portfolio?

4. Can you tell me what stories you like sharing with your family?

5. Is there anything else you would like to tell me about your portfolio? 


\section{Questions for children after portfolios have been accessible for 3 months}

1. Can you tell me about your portfolio?

2. Can you tell me who you like to look at your portfolio with?

3. Do you choose photographs or artwork to put in your portfolio?

4. Can you tell me what is special about your portfolio?

5. Do you like being able to choose when you can look at your portfolio?

6. Is there anything else you would like to tell me about your portfolio?

\section{Questions for teachers when portfolios have been accessible for 3 months}

1. Over the past 3 months how often have you sat down with a child and looked at and talked about their portfolios?

2. Over the past 3 months how many times have children invited you to sit with them and use their portfolios?

3. Are children talking to you more about their learning?

4. Over the past 3 months have children asked you if they can take their portfolios home or have they just taken them home?

5. Has this been the same for parents?

6. Over the past 3 months are there different ways children have used their portfolios?

7. Have you changed any of your teaching practices over the past 3 months that the portfolios have been readily accessible?

8. Are there any further comments you would like to make?

\section{Questions for parents when portfolios have been readily accessible for 3 months}

1. Over the past 3 months how often (daily/weekly/monthly) has your child asked you to look at their portfolio?

2. What does your child say and do when they are looking at their portfolio?

3. Over the past 3 months how often (daily/weekly/monthly) has your child taken their portfolio home?

4. Since your child's portfolio has become readily accessible do they use their portfolio in different ways at home?

5. Can you tell me if your child is talking to you more about their learning when they are looking at their portfolio with you?

6. Can you tell me if you think there are benefits for having your child's portfolio accessible for:
a. you
b. your child

7. Are there any further comments you would like to make? 


\section{Appendix N: Examples of data gathering and analysis techniques and tools}

Observation and analysis matrix example

\begin{abstract}
Observation 5/9/06
Maya and Dale are looking at Maya's portfolio book sitting at the table. Maya is looking in the portfolio book that was started at the centre she previously attended and I am continuing to add stories to the book. Maya points to a photo of the guinea pigs having a bath.
\end{abstract}

Maya: "who is that guinea pig?"

Dale: looks at the photo "no".

Maya: "Lynne do you remember the guinea pigs name?"

Lynne: "Yes I do it was called Api".

As the page is turned Dale points to the photo and says "look there is your Happy Birthday".

I leave to answer the phone. When I return Flora is looking with them at Maya's portfolio as the page is turned and there is a photo of Maya using the paint machine.

Flora: "I have that in my portfolio the paint machine that's cool".

Flora gets her portfolio and shows it to Maya after looking at a few more photos they put them back in the box.
Analysis

What is happening for children?-Maya is using her book to share with Dale her experiences at the centre that they had both previously attended.

Links to accessibility and how children use the portfolios-sharing thoughts and experiences with friends.

Revisiting prior experiences.

Problem-solving- as I am showing an interest Maya asks me the name of the guinea pig.

Connections and links-shared meaning and understandings-Dale could have pointed to the Birthday photo as it is of significance to her and she could be making links to the Birthday celebration photos in her portfolio.

Reflecting on experiences-sharing storiesFlora makes connections to her experiences of using the paint machine the photo is in her book shares this with her friends.

Ownership-the children can access their books, they can choose who they share them with.

\section{Reflection on action matrix example}

\begin{tabular}{|l|l|l|l|}
\hline $\begin{array}{l}\text { Action } \\
\text { Asked a child if they }\end{array}$ & $\begin{array}{l}\text { Reflection } \\
\text { I learnt the importance } \\
\text { of supporting } \\
\text { phildren's involvement } \\
\text { in the process. } \\
\text { Recognition of } \\
\text { phildren's ability to } \\
\text { participate joint } \\
\text { collaboration }\end{array}$ & $\begin{array}{l}\text { Significance } \\
\text { Developed an insight } \\
\text { of how my practice can } \\
\text { influence children's } \\
\text { reflection on their } \\
\text { learning. }\end{array}$ & $\begin{array}{l}\text { Implications } \\
\text { How will I do things } \\
\text { differently? Provide } \\
\text { children with a camera } \\
\text { to take photos. A tool } \\
\text { for children to choose } \\
\text { the contents to add to } \\
\text { their portfolios }\end{array}$ \\
Links to research & question how can I & & $\begin{array}{l}\text { the } \\
\text { encourage children to }\end{array}$
\end{tabular}




\section{Memo example: Reflections on children's interviews prior to portfolio accessibility}

$24^{\text {th }}$ May 2006.

Perhaps it may have been better to do the consent forms on a different day to asking the questions as the consent form that starts with the telling the story of my research took some time. Asking the questions seemed also to take along time and for younger children their attention span is not always sustained for that length of time. Perhaps they got bored. It may have been because it was something different. They could have been feeling uncomfortable or did not know what my expectations were. They were confused with my explanations about my research or my role as a researcher rather than a teacher.

I felt relaxed asking the children the questions and I feel they were comfortable with answering them most of the time. They told me if they did not want to answer the questions or be interviewed. Perhaps it was easier and felt relaxed as I knew the children and they know me we have responsive and reciprocal relationships.

I was very intrigued by the question Charlotte asked me, as she was the only child to ask me a question when given the opportunity. Charlotte asked me why I write. I told her about me wanting to know how she uses her portfolio and she and the other children think about their portfolios. Charlotte seemed interested and satisfied with my answer she listened attentively as I spoke to her. We were developing shared understandings and meanings of her portfolio.

When I first asked Charlotte if she would like to be part of my research and answer some questions she seemed rather reluctant and said "No". However, when I asked Maya and she agreed Charlotte changed her mind and asked me if she could do the form and answered the questions. Perhaps she was unsure of my expectations and because it was a more formal experience than what she was used to. Nonetheless when her friend agreed perhaps she said "yes" as she did not want to miss out experiencing something different. 


\section{Appendix O: Portfolio introduction: the purpose and contents}

\section{Portfolio introduction before research began}

Dear Parents,

This is the individual portfolio about

learning experiences at Preschool. The purpose of the portfolio is to provide you and your child with a record honouring their contributions to their learning.

The portfolios are useful for teachers because they form the basis for discussions between, teachers and parents, teachers and children and parents and children.

The portfolio will include documentation of learning. This will include written learning story observations, analysis objectives, strategies and evaluations which along with Te Whāriki the early childhood curriculum, forms the basis of our planning process for the child's individual learning plan. Teachers work together and plan as a team throughout the planning process.

Teachers will include photographs of your child documenting the links between the learning experiences, Te Whāriki and your child's learning. Selected artwork will also be included detailing the links between your child's art and the developmental art continuum. This portfolio is a private document. It will only be available for teachers, you and your child. It will only be shown to others with parent's written permission.

\section{Portfolio introduction after portfolio accessibility}

Dear

This is the individual portfolio about learning experiences at Preschool. The purpose of the portfolio is to provide you with a record of his/her contributions and learning experiences at Preschool.

The portfolios are useful to teachers because they form the basis of discussion between children, teachers and parents/whanau.

The portfolio will include documentation of learning. This will include written learning story observations, analysis strategies and evaluations which, which along with $\mathrm{Te}$ Whāriki the early childhood curriculum, form the basis of our planning process for the child's individual and group learning. Teachers plan and work together as a team throughout the planning process and encourage parents to work with us sharing photos, stories songs, interests, cultural aspects and customs from home.

The portfolios are kept out in the centre so that children can easily access them at any time. This allows children to revisit and see the learning that they have been doing in the centre. We encourage children to ask before they look at another child's portfolio. The document belongs to the child, and we respect this by encouraging their ownership of the portfolio.

If you would like an interview with me to discuss anything about Preschool or your child's learning, please do not hesitate to ask, and we can schedule a time.

(Underneath the above explanation are the teachers name and a photograph of the child).

\section{Current portfolio introduction}

Dear

This is the individual portfolio about

learning experiences at Preschool. The purpose of the portfolio is to provide you, and the Preschool teachers with a record of the basis for discussion.

We feel that portfolios should enable children, parents and teachers to work together to extend learning in the centre and the home environment.

We encourage families to work with us sharing photos, stories songs, interests, cultural aspects and customs from home. 
The portfolio will include written learning stories where teachers look at your child's learning and areas of interest they have. As teachers our role is to extend these interests and observe and evaluate how things have gone. The learning stories enable us to plan for your child's learning underpinned by Te Whāriki, the early childhood curriculum.

Portfolios allow children, parents and teachers to revisit and build on prior learning that has been engaged in.

We encourage children's ownership of their portfolio and have developed a culture where others must ask to look at your child's book.

If you would like to have an interview with one of the teachers to discuss anything about Preschool and your child's learning, please do not hesitate to ask and we can schedule a time.

Preschool teaching team

(Underneath the above explanation is a photograph of the child). 